\title{
ARISTÓTELES EN LA ESPAÑA DEL S. XVI. ANTECEDENTES, ALCANCE Y MATICES DE SU INFLUENCIA
}

\author{
Antonio Bravo García \\ Universidad Complutense
}

La cronología espiritual y la astronómica no concuerdan. Descartes está lleno de concepciones medievales; alguno de nuestros contemporáneos es además contemporáneo espiritual de Santo Tomás (A. Koyré).

\section{RESUMEN}

La finalidad de este artículo es explicar, mediante algunos testimonios significativos, de qué manera penetra en España el aristotelismo y cómo esta penetración del nuevo pensamiento aristotélico en Europa pone de manifiesto un permanente conflicto entre Edad Media y Renacimiento, fundamentalmente en España, donde el redescubrimiento y uso de las autoridades antiguas constituye a menudo un importante problema teórico. El autor muestra alguna de estas dificultades en varios dominios (filosofía, ciencia, literatura).

Palabras clave: Aristóteles, España, Edad Media, Renacimiento, Literatura, Ciencia, Filosofía.

\begin{abstract}
«Aristotle in Spain in sixteenth century. Background, significance and aspects of his influence». The aim of this paper is to explain, on the basis of some significant testimonies, the way in which Aristotelianism penetrates in Spain, and how this penetration of the new Aristotelian thought in the European countries reveals a permanent conflict between the Middle Age and the Renaissance, particularly in Spain, where the rediscovery and the use of the ancient authorities very often constitutes an important theoretical problem. The author shows some of these difficulties with examples from many fields (philosophy, science, literature).
\end{abstract}

Key words: Aristotle, Middle Age, Spain, Renaissance, Philosophy, Science, Literature.

\section{A MANERA DE PRESENTACIÓN DE UN TEMA QUE DE BIEN POCA NECESITA}

De acuerdo con lo que ya hemos escrito en un trabajo anterior ${ }^{1}$ y con lo que parece ser la opinión general, la tradición aristotélica española medieval y renacentista no constituye, en principio, una

1 «Los Parva naturalia en el Aristotelismo español: Alonso de Freylas y sus opiniones sobre la adivinación por medio de los sueños» en Los humanistas españoles y el humanismo europeo, (Simposio de la Universidad de Murcia, 1985), Murcia, 1991, p. 51. 
parcela separada e independiente de la europea; el Renacimiento, además, pese a lo que muchos investigadores creen, «penetró en España tan ampliamente como en otras naciones» ${ }^{2}$ y sus lazos con la cultura medieval, tenidos no demasiado en cuenta en algunas ocasiones por los estudiosos, reflejan más o menos los mismos patrones que pueden verse en otros lugares de Europa. No obstante, es lógico que en cada nación quepa señalar aspectos en el proceso de arraigo y desarrollo ulterior de las ideas venidas de fuera que, sin lugar a dudas, establecen diferencias nacionales, de grupo, personales 0 temáticas, aunque el carácter general de dicho proceso, en principio, tienda a ser bastante similar. Tanto para la lógica como para la metafísica, la ética, la filosofía natural, las ideas económicas, poéticas, retóricas o médicas aristotélicas, en su doble vertiente medieval y renacentista, existen numerosos estudios monográficos, en parte 0 en su totalidad bibliográficos y de mayor o menor profundidad, así como también detallados análisis del grado de aceptación o renuencia ante ellas que las propias ideas del Estagirita suscitaron entre los escritores españoles desde la Edad Media a nuestros siglos de oro, de forma que las críticas, influencias, citas, ecos o colorido aristotélico de nuestra literatura, tanto para estos siglos como para los siguientes, no son hoy un capítulo desconocido. Algunas obras, como el Repertorio de la historia de las ciencias eclesiásticas de España ${ }^{3}$ o, por citar otros ejemplos de muy diferente tenor, la Historia general de la medicina española de L.S. Granjel, ${ }^{4}$ la de la ciencia española de J. Vernet Ginés, ${ }^{5}$ el Diccionario histórico de J.M. ${ }^{a}$ López Piñero et alii ${ }^{6}$ o las diversas historias de la filosofía española de que disponemos, así como las de la literatura, son trabajos bien conocidos de todos, voluminosos algunos de ellos y con una excelente información general la mayoría; no entraremos, sin embargo, aquí a exponer en detalle esa bibliografía que, concreta o tangencialmente, trata del aristotelismo español, ya que nos bastará con remitir a nuestro trabajo mencionado, donde se dan algunas pistas sobre ella. Aparte de esto, nuestras bibliotecas, como es bien sabido igualmente, están llenas de manuscritos griegos y latinos que contienen las obras del de Estagira o de sus comentaristas, ya sea en el original griego ya en traducciones latinas, las más de las veces de los humanistas estas últimas y de copistas griegos del Medievo oriental o Renacimiento las otras, a las que hay que añadir un ingente número de traducciones realizadas por los árabes y pasadas luego al latín (sobre cuya especial transmisión tampoco es el caso hablar en este lugar) y, para terminar, todo el ejército de ediciones, versiones y comentarios impresos que pueden verse por doquier desde el siglo XV hasta nuestros días. Cabe, por supuesto, algunas veces, que testimonios conservados en nuestra patria tengan un destacado interés debido a alguna circunstancia especial; por ejemplo, el comentario de un tal Gratiadeus d'Ascoli al De anima, según ha estudiado J. de Raedermaeker, sólo se conserva en los manuscritos Escorialensis e.II.8 y Venetus 261, X 77, mientras que el único manuscrito de la obra de Nicolás Palmieri, en la que, en 1467-68, condenaba el escrito de Fernando

2 A. Guy, Historia de la filosofía española, trad. esp., Barcelona, 1985, p. 65.

3 Salamanca, 1967 y ss.

4 Nos interesa especialmente el vol. 2, La medicina española renacentista, Salamanca, 1980.

5 Historia de la ciencia española, Madrid, 1975; de gran importancia es el estudio de J. M. ${ }^{a}$ López Piñero, Ciencia y técnica en la sociedad española de los siglos XVI y XVII, Barcelona, 1979.

6 J. M. ${ }^{a}$ López Piñero, Th. Glick, V. Navarro Brotóns, E. Portela Marco (eds.), Diccionario histórico de la ciencia moderna en España, 2 vols., Barcelona, 1983.

7 «Informations concernant quelques commentaires du De anima», Bulletin de Philosophie Médiévale, 10-12 (1968), pp. 194-211. 
de Córdoba con el que éste participó en la disputa sobre si Aristóteles era o no mejor que Platón famoso cambio de impresiones de mediados del s. XV que contó con la participación de Besarión y otros eruditos-, ${ }^{8}$ se encuentra solamente en un códice de Monserrat (bajo la cota 882), según el conocido estudio de John Monfasani, ${ }^{9}$ quien menciona, además, a propósito del manuscrito un trabajo del profesor A. Mundó. No todos los códices son del mismo interés. Ahora bien, aparte de la posible bondad o rareza de sus textos, ya sea por sus datos codicológicos, su escritura, los escribas o traductores que en ellos han participado u otros muchos aspectos, todos los manuscritos pueden ofrecernos siempre elementos valiosos para las investigaciones tendentes a dar razón de los múltiples detalles de la transmisión aristotélica en nuestro país.

En líneas generales, una tipología de la producción literaria primaria del aristotelismo de la Edad Media al Renacimiento - no muy diferente de la que puede encontrarse en España, como se ha adelantado - podría ser, de forma harto resumida, la que a continuación expondremos. Ha sido Ch. B. Schmitt ${ }^{10}$ quien, en un libro de gran utilidad, se ha ocupado no hace mucho de sistematizarla. En primer lugar, obviamente, están los manuscritos e impresos con las obras, comentarios y traducciones a que se ha aludido. En el Renacimiento, en concreto, se pone en circulación una larga serie de comentarios griegos - los que hoy forman la magna colección de los Commentaria in Aristotelem Graeca, publicados por la Academia de Berlín en 29 volúmenes-cuya importancia no es necesario subrayar. ${ }^{11}$ Aparte de estos comentarios y de otros muchos en latín, podemos encontrar también los compendios, florilegios, series de sententiae, dicta y auctoritates y, algo más serias, las compilaciones, que consistían básicamente en un índice de conceptos aristotélicos; las Tabulae dilucidationum in dictis Aristotelis et Averrois de Marco Antonio Zimara (Venecia, 1562), por ejemplo, ilustran bien este último género cuya caricatura, como Schmitt señala, vendrán a ser las tablas a secas, es decir, unos cuadros sinópticos muy completos utilizados por los estudiantes como resumen y guía en sus estudios; algunas publicaciones de este tipo, de indudable valor, vieron la luz en nuestra patria, como más adelante tendremos ocasión de estudiar, y hay además otras, de contenido más universal, a caballo entre una tradición oral y otra escrita, que nos ilustran igualmente sobre el proceso general de configuración de unos topica que durante el Medievo y el Renacimiento estuvieron en la base de la transmisión del saber y de la composición de no pocas obras. ${ }^{12}$ Los humanistas, de

8 Un resumen breve de esta discusión, que hunde sus raíces en la Antigüedad, así como la relación de los participantes que en el Renacimiento en ella se distinguieron puede verse en J. Monfasani, George of Trebizond: A Biography: and Study of his Rhetoric and Logic, Leiden, 1976, pp. 201-229; véase también, con nuevos materiales, ídem, «Testi inediti di Bessarione e Teodoro Gaza», en M. Cotesi y E.V. Maltese (eds.), Dotti bizantini e libri greci nell'Italia del secolo XV. Atti del Convegno Int. (Trento [...] 1990), Nápoles, 1992, pp. 231-256 (recogido en Byzantine Scholars in Renaissance Italy: Cardinal Bessarion and other Emigrés. Selected Essays, Aldershot, Hampshire, 1995).

9 George of Trebizond, p. 218, n. 108.

10 Aristotle and the Renaissance, Cambridge, Mass.-Londres, 1983, pp. 34-63; para este resumen remitimos una vez más a nuestro trabajo «Los Parva naturalia».

11 Berlín, 1891 y ss. (hay reimpr.). Véase, en general, sobre los comentaristas, R. Sorabji (ed.), Aristotle Transformed. The Ancient Commentators and their Influence, Ithaca, Nueva York, 1990.

12 Tema éste extraordinariamente interesante, del que no podemos hablar aquí; el lector puede encontrar reflexiones muy sugestivas en W.J. Ong, «Commonplace Rhapsody: Ravisius Textor, Zwinger and Shakespeare» en R.R. Bolgar (ed.), Classical Influences on European Culture A.D. 1500-1700. (Proceedings of an International Conference [...] Cambridge, 1974), Cambridge, 1976, pp. 91-126. 
otra parte, publicaron una serie de estudios monográficos que, desde la inmortalidad del alma a las virtudes ciudadanas, están dedicados a analizar la vasta obra de Aristóteles; ${ }^{13}$ hay que incluir, como un «género» más, las introducciones colocadas en las ediciones, «género éste no sólo valioso en sí mismo sino extraordinariamente rico en información sobre las circunstancias que solían rodear la realización de la edición», ${ }^{14}$ como hemos señalado también en nuestro trabajo citado. Finalmente, a las paráfrasis, que no escasean, habría que añadir las comparaciones entre Platón y Aristóteles, un «género» también del que ya hemos dicho algo. En resumidas cuentas, no es poco lo que de esta tipología de obras encontramos en España y, por lo que se refiere a la tradición indirecta, el panorama español no se diferencia tampoco en mucho del que ofrecen otros lugares de Europa. Cierto es, sin embargo, que no todos los tipos de obras han recibido la misma atención de los investigadores y que, por ello, la presencia de Aristóteles en algunos ámbitos concretos ha quedado algo desatendida («espejos de príncipes», emblemas, refranes, ${ }^{15}$ algunas obras técnicas, etc.); sin embargo, no lo es menos que otras parcelas, los florilegios, por ejemplo, han merecido un interés especial, ${ }^{16}$ cuyos resultados permiten hacernos una idea bastante clara de la manera en que medievales y renacentistas tuvieron acceso al legado aristotélico. Baste con lo dicho como necesaria introducción al meollo de nuestro estudio, ${ }^{17}$ cuyo propósito - ya va siendo hora de precisarlo — no es una mera exposición

13 Una rápida visión de parte de esta producción puede encontrarse en $\mathrm{P}$. O. Kristeller, El pensamiento renacentista y sus fuentes, trad. esp., Méjico, D.F., 1982, pp. 225-279 («Los conceptos de hombre en el Renacimiento»), libro compilado por M. Mooney, que recoge una serie de artículos del autor.

14 Véase, por ejemplo, B. Botfield, Prefaces to the First Editions of the Greek and Roman Classics and of the Sacred Scriptures, Cambridge, 1861, y, sobre todo, C. Dionisotti y G. Orlandi, A. Manuzio editore. Dediche. Prefazioni. Notte ai testi, 2 vols., Milán, 1975.

15 Sobre algunos recogidos en G. Correas, Vocabulario de refranes y frases proverbiales y otras fórmulas comunes de la lengua castellana [...], Madrid, 1924, véase L. Gil Fernández, Panorama social del humanismo español (15001800), Madrid, 1981, p. 133.

16 Véase, por ejemplo, Ong, «Commonplace», pp. 93 y ss., así como los estudios de J. Hamesse, «Les florilèges philosophiques, instruments de travail des intellectuels à la fin du Moyen Âge et à la Renaissance», en L. Bianchi (ed.), Filosofia e teologia nel Trecento. Studi in ricordo di E. Randi, Lovaina la Nueva, 1994, pp. 509-533, e «ll modello della lettura nell' età della Scolastica», en G. Cavallo y R. Chartier (eds.), Storia della lettura, Roma-Bari, 1995, pp. 91-115 (pp. 103-108 en especial, sobre las razones del éxito de los florilegios y compendios); de la misma autora, el libro Les auctoritates Aristotelis. Un florilège médiéval: étude historique et édition critique, Lovaina, 1974, es una excelente investigación sobre una obra concreta de extraordinaria influencia; y debe tenerse en cuenta igualmente el estudio de Schmitt, «Auctoritates, Repertorium, Dicta, Sententiae, Flores, Thesaurus, and Axiomata: Latin Aristotelian Florilegia in the Renaissance», en J. Wiesner (ed.), Aristoteles Werk und Wirkung. Paul Moraux gewidmet II, Kommentierung, Überlieferung, Nachleben, Berlín-Nueva York, 1987, pp. 515-537. La producción de florilegios, de otro lado, continúa en el Renacimiento. Pese a que los humanistas, entre ellos Vives, tendieron a sustituir esta literatura secundaria por la consulta directa de las fuentes y la criticaron, sin embargo no consiguieron suprimirla; incluso se produjeron florilegios nuevos realizados a partir de las nuevas traducciones aristotélicas renacentistas, como Hamesse, «La diffusion des florilèges aristotéliciens en Italie du XIVe au XVIe siècle» en G. Roccaro (ed.), Platonismo e Aristotelismo nel Mezzogiorno d'Italia (secc. XIV-XVI). (Testi della VII Settimana Residenziale di Studi Medievali [...] Carini, 1987), Palermo, 1989, pp. 39-54, e ídem, «Les florilèges», pp. 503 y ss., ha estudiado. Efectivamente, «le genre évolue dans certains cas, mais ne s'éteint pas. On constate que la production se diversifie. Ils sont utilisés tant par des lettrés, que par des prédicateurs ou des enseignants. Ils servent de recueils documentaires pratiques et faciles d'accès, de même qu'ils continuent à être employés pour l'enseignement. Dès le XVIe siècle d'ailleurs, les Jésuites» —señala Hamesse, ibídem, p. 505, con bibliografía— encourageront leur utilisation». Es de destacar, finalmente, que no aparecen florilegios de Platón, autor que «est étudié en version intégrale» (ibídem p. 506).

17 Recoge este trabajo, con añadidos y notas posteriores y dividido en dos partes a causa de su extensión, una lección impartida en 1994, en un curso de doctorado de la Universidad de Zaragoza dirigido por el Dr. A. Escobar. 
de pasajes entresacados de una lista de obras de variada naturaleza, con pretensiones (siempre vanas, por supuesto) de exhaustividad, obras, además, cuyos modelos, en no pocas ocasiones, vienen de la Edad Media, sino más bien el acercarnos a unas pocas de aquéllas, escogidas, y pasar revista a la vez a ciertos aspectos generales que nos ayuden a dar razón de cómo el aristotelismo se presentó en vestidura hispana y a señalar cuál fue la inténción, crítica o no (porque de todo hubo), que animó a quienes de él aceptaron servirse. Nos ocuparemos básicamente de textos españoles del s. XVI y, entre éstos, haremos un uso menor de los que tienen que ver con la teología y la filosofía - aspectos relativamente bien conocidos-; desterraremos además los escritos en verso y pasaremos un poco por alto las grandes obras literarias, de las que la bibliografía científica reciente se ha ocupado ya con profusión. $^{18}$

\section{LOS CAMBIOS DE MENTALIDAD ENTRE LA EDAD MEDIA Y EL RENACIMIENTO. NUESTRO RENACIMIENTO Y EL ITALIANO}

Esta ojeada que acabamos de echar a la tradición aristotélica española, casi una repetición de lo que ya dijimos en otro lugar, debe dejar paso ahora a la consideración de un aspecto que plantea no pocas dificultades: se trata de los cambios que el análisis, lectura, enseñanza y mero disfrute de esos textos han ido experimentando con el paso del tiempo, como consecuencia de los sucesivos cambios de mentalidad. ¿Qué preguntas cabe hacernos a este respecto? ¿Cuáles son las interpretaciones que se han ido barajando? Vayamos por partes. «La Edad Media, muy especialmente en sus primeros siglos,» - ha escrito José Antonio Maravall en un libro al que nos habremos de referir de continuo, ${ }_{-}^{19}$ tanto por su riqueza de información como por la profundidad de sus planteamientos - «vive una especie de contemporaneidad ${ }^{20}$ de todo cuanto ha sido y de todo cuanto es. La conciencia histórica, que tan franco arranque había tenido en el primitivo cristianismo, madura lentamente en los siglos medievales y es, naturalmente, incapaz de vencer en los primeros tiempos esa intemporal conciencia de contemporaneidad». El pasado, pues, se aplica muchas veces en lo

18 Por lo que toca a las líneas generales de la transmisión textual de los textos aristotélicos y a algunos aspectos de la tradición aristotélica poco es lo que diremos; señalemos aquí, de todas formas, unos cuantos estudios de interés como D. Harlfinger, «Einige Grundzüge der Aristoteles-Überlieferung», en D. Harlfinger (ed.), Griechische Kodikologie und Textïberlieferung, Darmstadt, 1980, pp. 447-483; I. Düring, «Von Aristoteles bis Leibniz. Einige Hauptlinien in der Geschichte des Aristotelismus», Antike und Abendland, 4 (1954), pp. 118-154 (recogido en P. Moraux [ed.], Aristoteles in der neueren Forschung, Darmstadt, 1968, pp. 250-313); A. Buck, Die Rezeption der Antike in den romanischen Literaturen der Renaissance, Berlín, 1976, pp. 91 -99 (hay trad. it.); y F. van Steenberghen, Aristotle in the West. The Origins of Latin Aristotelianism, trad. ingl., Nueva York, 1970 (es reimpr.). Los dos vols. del homenaje a Moraux ya citado (1985 y 1987) son una mina de información. Además, A. Escobar, «Sobre la fortuna de Aristóteles en España», Revista Española de Filosofía Medieval, 1 (1994), pp. 141-148, pese a su brevedad, es una excelente introducción a la bibliografía científica con que contamos.

19 Antiguos y modernos. La idea de progreso en el desarrollo inicial de una sociedad, Madrid, 1966, p. 203 (hay reimpr.).

20 Observaciones sobre esta contemporaneidad pueden verse, por ejemplo, en C. García Gual, Introducción a la mitología griega, Madrid, 1992, p. 220 (recogiendo la opinión de A. Heller a propósito del «cuerpo mítico unitario»); J. Delumeau, La civilización del Renacimiento, trad. esp., Barcelona, 1977, p. 111; y otros autores. 
que es el presente y esto se suele ver, por ejemplo, en las representaciones de héroes antiguos (Aquiles o Eneas vestidos con armaduras y ropas contemporáneas) o algunos otros detalles, sorprendentes en verdad, como el de hacer de Aristóteles (omnipresente por doquier, cierto es) un español, o bien crear una leyenda sobre un Virgilio nacido en Córdoba; en el primer caso, por ejemplo, hay que señalar el caso del obispo don Lucas de Tuy. ${ }^{21}$ Pero lo que más nos importa a este respecto es subrayar nuestra coincidencia con Maravall en que esta «apropiación» y, sobre todo, esta contemporaneidad, resulta de interés para nuestro empeño, dado que es la razón de que, dentro de la cultura medieval, se convierta en suposición bien arraigada que «el transcurso del tiempo enriquecía a los pasados, llegando a tenerse a los antiguos como los más ricos de experiencia, porque no se les veía como pretéritos, sino como intemporalmente presentes, cargados de la experiencia que el paso centenario de los años iba depositando sobre ellos». ${ }^{22}$ Un escritor de entre los siglos XII y XIII, canciller de Alfonso VIII, Diego García de Campos, nos dirá, por ejemplo, que brillan «parisienses in theologia; bononienses in iustitia; salernitanos in physica; athenienses in philosophia»; para él, está claro que existe un evidente plano de contemporaneidad entre los diversos grupos citados, lo que hace que se siga viendo lo «antiguo» como vivo en la contemporaneidad, digno de respeto y admirable en muchos sentidos.

El ataque frontal a lo «antiguo», con la victoria sobre ello de lo «moderno», tardará en llegar todavía y esta lucha - a la que ha sido dedicada una inmensa literatura (de la que sólo en parte se hablará aquí), y que terminará con ese casi idílico «continuum de pensamiento» al que nos hemos referido- revestirá muy variados tonos, como es cosa también sabida. Por el momento, baste con decir que no se nos debe ocultar que la recuperación de los saberes clásicos en el Renacimiento habrá de comportar igualmente, en cierto modo, una consideración de éstos como doctrina válida intemporalmente, aunque ello suponga aceptar la paradoja —señalada, entre otros, por J. Pérez- ${ }^{23} \mathrm{de}$ que el culto a la Antigüedad acabó por «reforzar el criterio de autoridad contra el que los huma-

21 Véase O. di Camillo, El humanismo castellano del siglo XV, Valencia, 1976, p. 119; K.A. Blüher, Séneca en España. Investigaciones sobre la recepción de Séneca en España desde el siglo XIII hasta el siglo XVIII, trad. esp., Madrid, 1983, p. 78; F. Rico, «Aristoteles Hispanus: en torno a Gil de Zamora, Petrarca y Juan de Mena», IMU, 10 (1967), recogido en A. Egido et alii, Mitos, folklore y literatura, Zaragoza, 1987, pp. 57-77; para más precisiones, tanto bibliográficas como de otro tipo, véase también A. Gómez Moreno, España y la Italia de los humanistas. Primeros ecos, Madrid, 1994, pp. 135 y ss. Existe igualmente una bibliografía dedicada a estudiar la idea de que Aristóteles fue cristiano; véase, por ejemplo, Maravall, «La estimación de Sócrates y de los sabios clásicos en la Edad Media española», RABM, 62 (1957), recogido en Estudios de historia del pensamiento español. Serie primera. Edad Media, Madrid, 1983, p. 298, aunque no deja también de haber ejemplos medievales de burla de la persona del Estagirita en la iconografía o la literatura, como es conocido; a este último propósito, G. Highet, The Classical Tradition. Greek and Roman Influences on Western Literature, Oxford, 1967, p. 57 (es reimpr; hay también trad. esp.), escribe que «the Lay of Aristotle, which shows the philosopher saddled and bridled by a pretty Indian girl, and cavorting about the garden as an object-lesson for Alexander, is pure invention on the typical fabliau theme of the power and tricksiness of women»; puede verse una reproducción del conocido dibujo de Joseph Heinz el Viejo (1600) en J. Hale, The Civilization of Europe in the Renaissance, Nueva York, 1995, p. 573, quien habla también de «a popular medieval exemplum of the dangerous power of women over wisdom».

22 Maravall, Antiguos, p. 204.

23 «Renacimiento y escolástica», en V. García de la Concha (ed.), Literatura en la época del emperador: (Academia Literaria Renacentista, 5), Salamanca, 1988, p. 18. Para H. Baron, «La querelle entre los antiguos y los modernos como problema para los estudios actuales sobre el Renacimientom, influyente artículo publicado inicialmente en inglés en el Journal of the History of Ideas, 20 (1959), reimpreso posteriormente en P.O. Kristeller y Ph. P. Wiener (eds.), Renaissance Essays from the Journal of the History of the Ideas, Nueva York-Evanston, 1968, y vuelto a ser recogido más tarde, esta 
nistas se habían esforzado tanto». Ni Tolomeo ni las matemáticas griegas, por poner un par de ejemplos citados por Pérez, estaban ya en sintonía con los nuevos tiempos y, por ello, empecinarse en volver a este autor y materia sin la menor desviación era, en cierto modo, caer en los mismos errores de la criticada escolástica. Es en este sentido como pueden explicarse no pocas de las críticas antiaristotélicas que veremos desfilar por estas páginas o, en buena parte, la propia oposición a los «antiguos». Efectivamente, la realidad sobrepasaba en ocasiones a los libros y no había manera de obviar el problema sino aceptando que los nuevos tiempos habían desmentido, puesto en duda 0 completado lo que por los antiguos había sido otrora inventariado, entendido o supuesto. ${ }^{24}$ Así pues, como ejemplo entre muchos, recordemos que el portugués García de Horta, autor de una obra sobre las plantas del Nuevo Mundo, quitará importancia en 1563 al testimonio de Dioscórides ya que lo que él se propone escribir, nos dice, versa sólo acerca de «lo que sabe que es cierto» y conoce: en concreto numerosas plantas desconocidas por el estudioso griego. ${ }^{25}$ Este doble celo, consistente en detectar errores de los antiguos y en tomar en consideración los datos aportados por los nuevos tiempos, proceder muy frecuente en la época pero reconocible también en el Medievo, ${ }^{26}$ saldrá a relucir con brillo especial en la obra de un nuevo personaje del mundillo intelectual: el naturalista; para John Hale, ${ }^{27}$ en efecto, el suizo Konrad Gessner, autor de una Historia de los animales (tal como Aristóteles) o el inglés John Kay, que escribió sobre perros de su país, son buenos ejemplos de autores de esta clase. En otros casos, la crítica no versará solamente sobre unos datos incompletos (los de los antiguos), sino sobre las inferencias erróneas que el manejo de información incompleta ha condenado a extraer a aquéllos; por ejemplo, aprovechando que en 1572 apareció una nueva estrella cerca de la constelación de Casiopea, un astrónomo y profesor de hebreo de Valencia, Jerónimo Muñoz, escribió en su Libro del nuevo Cometa, y del lugar donde se hazen; y como se vera por las Parallaxes quan lexos estan de tierra; y'del Prognostico deste, Valencia 1573, que Aristóteles había estimado de forma muy poco correcta la

vez en español, en Baron, En busca del Humanismo cívico florentino. Ensayos sobre el cambio del pensamiento medieval al moderno, trad. esp., Méjico, D.F., 1993, p. 322, en la época de la querelle (con G. Hakewill, Apology [...] of the Power and Providence of God [...] and Censure of the Common Errour Touching Nature's Perpetuall and Universal Decay, por ejemplo, en el s. XVII), nos encontramos con un cuadro histórico en el que «una época de ciencia y filosofía nuevas se opone al Renacimiento precedente, al cual se identifica con una sumisión al clasicismo, digna de un esclavo, al yugo tiránico de los modelos de la Antigüedad; y otro en el cual el Renacimiento aparece como una lucha entre la veneración a la Antigüedad, que conduce al clasicismo, y una defensa de los poderes innatos y de la igualdad del hombre moderno, que conduce a la querelle -lucha que se continuó el tiempo suficiente como para preparar el campo a algunos de los razonamientos más vitales de la querelle del siglo XVII». La paradoja aludida se halla delimitada claramente por Baron en esta afirmación.

24 En general, véase sobre esta cuestión, aunque sólo como introducción, J.M. García González; «El pensamiento científico en el Humanismo renacentista: tradición y superación de los modelos greco-latinos», en J.A. Sánchez Marín y M. López Muñoz (eds.), Humanismo renacentista y mundo clásico, Madrid, 1991, pp. 107-130.

25 Tomamos la cita de Hale, The Civilization, p. 517.

26 Por ejemplo, errores de Plinio y Tolomeo fueron denunciados por Roger Bacon en su Opus maius (compuesto en Oxford un poco después de 1266), en función de lo que las informaciones de los viajeros contemporáneos, los franciscanos Carpini y Rubruck, habían aportado; véase J.R.S. Phillips, The Medieval Expansion of Europe, Oxford, 1988, pp. 199 y ss.

27 The Civilization, p. 528. 
naturaleza del cosmos; ya que, en opinión del filósofo de Estagira, nada se corrompía o generaba fuera del mundo sublunar. ${ }^{28}$

En fin, más adelante habremos de pasar revista con mayor detenimiento a algunas de las críticas que, en la amplia variedad de su tipología, nos ofrecen los autores españoles del s. XVI y, también, a las novedades que aportan con respecto a la concepción que la Edad Media tenía del saber. Retomando por el momento el hilo de nuestra exposición, señalemos que, en España, la imagen de la filosofía antigua como algo digno de admiración y respeto fue siempre, tanto en la Edad Media como en nuestro renacimiento, más bien Aristóteles que Platón; así, al menos, opinan, entre otros, especialistas como G. Fraile ${ }^{29}$ y J. L. Abellán. ${ }^{30}$ El primero de ellos ${ }^{31}$ trae a colación el testimonio de M. Menéndez Pelayo con frases laudatorias a propósito del nutrido aristotelismo hispano. Aparte de ofrecer un elenco de traductores y traducciones (Juan Ginés de Sepúlveda, Juan Bautista Monllor, Pedro Simón Abril, Andrés de Laguna, Sebastián Pérez, Diego de Funes y Mendoza, Vicente Mariner de Alagón y Juan de Vergara), Fraile, que sigue de cerca la erudita obra de M. Solana, ${ }^{32}$ pasa revista a los aristotélicos del s. XVI, entre los que hay que contar a Francisco Ruiz, Fernando de Roa, Diego Ramírez de Fuenleal, Pedro de Espinos, Miguel de Palacios, Alonso Pérez, Juan Echalaz (todos ellos representantes del aristotelismo salmantino), así como a otra legión de aristotélicos formados en Alcalá, Valencia o en otras regiones españolas, autores todos (junto con algunos antiaristotélicos de pro o simplemente críticos: Hernando Alonso de Herrera, Pedro Núñez Vela y el más tardío Manuel Bocarro Francés y Rosales, amigo de Galileo, por ejemplo) de obras de diverso estilo, comparables a las de la tipología esbozada por el prematuramente desaparecido Schmitt, a quien antes hacíamos referencia. Por lo que se refiere a Abellán, ${ }^{33}$ que igualmente se sirve de la benemérita obra de Marcial Solana, en general su opinión se aproxima a la de Fraile; recoge además ${ }^{34}-\mathrm{y}$ esto nos parece de interés traerlo a estas páginas - un juicio muy positivo a propósito del aristotélico Francisco Ruiz, fallecido a mediados del siglo XVI, que toma de Solana:35 «La labor del abad Ruiz tiene valor extraordinario como obra de paciencia típicamente benedicti-

28 Ibídem, p. 571. Como escribe L. Villoro, El pensamiento moderno. Filosofia del Renacimiento, Méjico, D.F., 1992, p. 16, ya «desde mediados del siglo XV, Nicolás de Cusa sostiene la idea de que la separación entre el mundo sublunar y el celeste es ficticia. No hay ninguna razón para suponer que el cambio y la corrupción sólo se den en la tierra; es más razonable pensar que una sola ley rige en ambos mundos, de modo que las mismas propiedades de la Tierra las comparte la esfera de las estrellas fijas. El universo es, para él, una "explicación" (explicatio) de Dios, aunque imperfecta e inadecuada, porque desarrolla en una multiplicidad de formas lo que en Dios se encuentra en una unidad indisoluble (complicatio)». Marcado todavía con rasgos medievales, deudor en grado apreciable del Corpus Hermeticum. lector apasionado de la filosofía antigua y coleccionista de manuscritos, Nicolás es uno más entre los críticos de Aristóteles, y su pensamiento ha sido considerado por E. Cassirer, El problema del conocimiento en la filosofía y en las ciencias modernas, I,

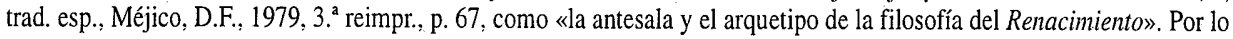
que toca a Jerónimo Muñoz y a su empleo del paralaje para ubicar la «nova» fuera del mundo sublunar, véase V. Navarro Brotóns, s.v., Diccionario histórico, II, pp. 91 y ss.

29 Historia de la filosofía española I. Desde la época romana hasta fines del siglo XVII, Madrid, 1985, 2. ${ }^{\text {a }}$ ed.

30 Historia crítica del pensamiento español. II. La Edad de Oro, Madrid, 1979.

31 Fraile, o.c., p. 231.

32 Historia de la filosofia española. Época del Renacimiento, II, Madrid, 1941.

33 Historia crítica, p. 173.

34 Ibídem, p. 181.

35 Historia de la filosofía, pp. 78-79. 
na, de perfecto conocimiento de los libros y doctrinas de Aristóteles y de utilidad enorme para el fácil estudio de la filosofía del Estagirita; ese mérito crece en extremo si se considera que el monje castellano fue quien primeramente acometió en el mundo la tarea de presentar en un índice ordenado y de fácil manejo toda la enciclopedia filosófica de Aristóteles. Ni con lo muchísimo que hoy se ha progresado en el estudio de las doctrinas del filósofo, ni con las ediciones esmeradísimas que se han publicado de las obras del Estagirita, ni con la multitud de tablas y referencias con que se han completado estas ediciones contemporáneas, ha perdido nada del valor que tenía en el siglo XVI el monumental Index del abad de Sahagún; y es que fray Francisco Ruiz acertó a componer una obra verdaderamente perenne». Al Index locupletissimus duobus tomis digestus, in Aristotelis stagiritae opera, quae extant (Sahagún, 1540) de Ruiz, que fue calificado por A. Bonilla y San Martín de «colosal y verdaderamente ciclópeo», ${ }^{36}$ ningún comentario le dedica sin embargo, Schmitt.

En Alcalá, como en otras partes, según ha estudiado el padre Urriza, ${ }^{37}$ se consolidaron también pronto los estudios aristotélicos, ${ }^{38}$ pero conviene señalar que la influencia en nuestro suelo de este filósofo - que, como hemos dicho, llegó a ser considerado en épocas anteriores un «español»— no debe tomarse siempre como un rasgo de «medievalismo» no atemperado por el humanismo que nos venía de Italia. Maravall, en su penetrante estudio, hace alusión a que, en aquella península, Leonardo Bruni (1370-1444), por ejemplo, fue un «exaltador del pensamiento y del estilo de Aristóteles» y junto con él hubo otros más. Además, es algo bien sabido, aunque en ocasiones olvidado, que el aristotelismo y el humanismo se desarrollaron en tierras italianas prácticamente a la par, de forma que no es muy acertado contraponer sin más a este propósito la luz del humanismo con la oscuridad del desaparecido Medievo; volveremos a insistir sobre esta idea, precisando su alcance, de la mano de P.O. Kristeller. Por último, los intereses del cardenal Cisneros en nuestra patria eran, como es de suponer, primariamente eclesiásticos; no obstante, D.J. Geanakoplos, ${ }^{39}$ entre otros autores, ha señalado que fue su deseo mejorar la edición aldina de Aristóteles y traducir al latín otra vez al filósofo y, para ello, encargó la labor, ingente de verdad, a Juan de Vergara, aunque ésta nunca fue acabada. Tradujo Vergara el De anima, la Física y la Metafísica, al parecer como resultado de una actividad que comenzó en 1514; sin embargo, J. López Rueda, en su conocido libro sobre el helenismo hispano del s. XVI, ${ }^{40}$ señala que el ms. Matritensis BN 13.000, copia de un Toletanus, que conserva su labor, no es lo que sugieren las noticias anteriores. Su así llama-

36 Véase Guy, Historia, p. 86.

37 La preclara Facultad de Artes y de Filosofia de la Universidad de Alcalá de Henares en el Siglo de Oro, Madrid, 1942; este autor, que sigue a Menéndez Pelayo, afirma que «para lo que a la Universidad de Alcalá se refiere, es de notar que en el siglo que estudiamos es quizá más abundante en producción filosófica que ninguna otra, aun que la misma Universidad veterana de Salamanca», (ibídem, p. 346). Tras las veleidades de la lógica decadente, que duraron no poco, Urriza afirma que el auténtico restaurador del aristotelismo en Alcalá fue Gaspar Gardillo de Villalpando, cuya gloria consistió en «emprender la guerra contra los sofistas y ganarla» (ibídem, p. 369).

38 Para un estudio de la actitud e intereses de los alumnos que abarrotaban nuestras universidades, especialmente en el s. XVI, con resultados bastante negativos por cierto, se verá Gil Fernández, Panorama, pp. 74 y ss.

39 D.J. Geanakoplos, Greek Scholars in Venice. Studies in the Dissemination of Greek Learning from Byzantium to Western Europe, Hamden, Connecticut, 1973, p. 244 (es reimpr.)

40 J. López Rueda, Helenistas españoles del siglo XVI, Madrid, 1973, p. 371. 
da traducción «es simplemente un resumen del texto griego y no una traducción literal. El sistema seguido por nuestro helenista» - prosigue este investigador- «consiste en compendiar muy sucintamente los pasajes secundarios y, en cambio, ceñirse más a la letra en su interpretación de los párrafos esenciales». Resulta curioso señalar, por otro lado, que, según el inventario de libros del Colegio de S. Ildefonso, fondo que pasó a la Biblioteca de la Universidad de Alcalá, ya en 1512 tenemos allí la aldina aristotélica, de acuerdo con lo que M. Bataillon ha señalado. ${ }^{41}$

¿Qué significado tiene, pues, realmente, nuestro pujante aristotelismo de esta época? ¿Cabe interpretarlo como una supervivencia medieval simplemente? La respuesta a ambas preguntas es importante, ya que de ella ha dependido que no pocos estudiosos, con la repulsa del resto, hayan apostado por un posible alejamiento de España de las fuentes renacentistas y el consiguiente apego exagerado a los veneros medievales, calificados normalmente de tradicionales en exceso, cuando no de caducos y agostados. ${ }^{42}$ ¿Es, por el contrario, un aristotelismo novedoso, propiamente renacentista diríamos? ¿Cómo es, de otro lado, el aristotelismo del Renacimiento italiano? Pasemos a verlo.

a) De todos es conocido, como ya se ha dicho, que entre la Edad Media y el Renacimiento o, si se quiere, entre la escolástica y el humanismo, se producen ciertos cambios de perspectiva en el pensamiento europeo; no podemos entrar aquí a fondo en estas ni en otras disquisiones terminológicas pero es necesario, antes de proseguir, clarificar un tanto las ideas al respecto. Humanismo y Renacimiento son como los rostros de un Jano bifronte (la comparación, junto con algunas ideas, las tomamos de Salvatore Impellizzeri $)^{43}$ que caracterizan a una época, aunque no todos los investigadores coinciden en ello, claro está, o bien optan por emplear otras formulaciones para mostrar su anuencia. ${ }^{44}$ La palabra humanismo, relacionada con humanitas en el sentido de Varrón o Cicerón, equivale al término griego paideiva, ${ }^{45}$ es decir la educación del hombre en

41 Erasmo y España. Estudios sobre la historia espiritual del siglo XVI, trad. esp., Méjico, D.F., 1966, 2. ed., p. 31, n. 37 .

42 Sobre las posturas que, desde la pervivencia de las influencias medievales (F. de Onís, A. F. G. Bell y otros), llegan hasta la negación de un renacimiento en España (V. Klemperer), lo afirman o valoran soluciones de compromiso, pueden verse los trabajos panorámicos, con excelente bibliografía, de F. Rico, «Temas y problemas del Renacimiento español», en Historia y crítica de la Literatura Española al cuidado de F.R., II: F. López Estrada, Siglos de Oro: Renacimiento, Barcelona, 1980, pp. 1-27; y J.F. Alcina y F. Rico, «Temas y problemas del Renacimiento español», en el vol. 2/1, Primer suplemento (Barcelona, 1991) de la misma Historia y critica ya citada, pp. 5-25. Véase también J.L. Abellán, El Erasmismo español. Una historia de la otra España, Madrid, 1976, pp. 17-49.

43 «Lumanesimo bizantino del IX secolo e la genesi della "Biblioteca di Fozio"», RSBN, 6-7 (1969-70), especialmente pp. 9-16 (recogido como apéndice en La letteratura bizantina da Costantino a Fozio, Bolonia, 1975, pp. 297-365).

44 Para Gómez Moreno, España, p. 26, por ejemplo, de acuerdo con la orientación de sus pesquisas y sin que ello suponga el menor deseo de imponer un «metalenguaje personal», «se revela la mayor dificultad para que ambos conceptos puedan llegar a coincidir en la erudición historiográfica moderna: mientras el estudio del Humanismo se limita, de hecho, a un grupo reducido de individuos, las señas de identidad del Renacimiento se buscan en la sociedad toda».

45 Ya en Diógenes Laercio, 2, 70, en la biografía del filósofo Aristipo de Cirene, la palabra à $\nu \theta \rho \omega \pi\left\llcorner\sigma o^{\prime \prime}\right.$ (humanismus) aparece como equivalente a $\pi \alpha \iota \delta \epsilon i \alpha, \pi \alpha i \delta \epsilon u \sigma \iota^{₹}$, lo que equivale a decir que, al menos a mediados del s. III d. $C$., la época en que escribe Diógenes, era una palabra en uso. En latín clásico, sin embargo, no aparece humanismus, aunque posteriormente Petrarca y otros muchos se servirán de humanitas, studia humanitatis y litterce humaniores, etc., y será en 1808 cuando el educador alemán F.J. Niethammer acunará el término Humanismus «para significar que la educación 
su verdadera forma. Humanismo, pues, es para Impellizzeri el rostro que mira hacia atrás, «che si rivolge al passato, che tende al recupero dei valori espressi dalle civiltà classiche, come valori eterni, paradigmatici, assoluti, rispecchianti un'umanità ideale, modello universale ed esemplare, su cui si possa educare e plasmare la successiva umanità». ${ }^{46}$ Frente a esto, la actividad de los humanistas para conseguir llevar a cabo esa educación ${ }^{47}$ que había de llevar hasta sus discípulos los verdaderos valores humanos, frente a la concepción básicamente teológica del Medievo, supuso de una manera amplia y general una auténtica labor de renovación, de búsqueda y estudio de la Antigüedad, una renovatio o renascentia, un Renacimiento en suma que, de muy diversas maneras y merced a diversas causas directas o indirectas, se había encargado (y lo seguía haciendo) de transformar las mentalidades. Desde que Benvenuto Campesani de Vicenza (muerto en 1323), un temprano enamorado de la Antigüedad, ${ }^{48}$ tituló un epigrama suyo dedicado al descubrimiento de un manuscrito de Catulo como Versus [...] de resurrectione Catulli poete veronensis, ${ }^{49}$ el concepto de resurrección o renacimiento fue del dominio público y, al emplear este término, los propios humanistas no hicieron otra cosa que aplicar nociones cristianas, provenientes de la Edad Media, utilizadas ya para el renacer del alma, como W. Jaeger ha mostrado. ${ }^{50}$ Tras una serie de

secundaria atendía ante todo a los clásicos griegos y latinos, oponiéndola así - tomamos esta opinión de Kristeller, «El movimiento humanista», artículo publicado en 1955 y recogido en El pensamiento renacentista, p. 39- a las crecientes demandas de que la educación fuera más práctica y más científica». En humanitas, de otra parte, según Cicerón, sono impliciti —así nos dice Impellizzeri, «L'umanesimo bizantino», p. 9, n. 1 (en p. 10)— «i valori ideali creati dai Greci nelle grandi opere dell' età classica; i quali sono considerati paradigmatici sia dal punto di vista artistico-formale sia dal punto di vista etico. Ahora bien, el concepto de ejemplaridad» aplicado a las obras griegas viene ya de antiguo y nace en la Grecia helenística. Por lo que toca finalmente al término humanista, documentado ya a principios del XVI para designar a los profesores de humanitas o humanae litterae y formado sobre el modelo de «jurista» 0 «artista», Rico, El sueño del Humanismo (De Petrarca a Erasmo), Madrid, 1993 p. 78, lo califica de «bastardo y plebeyo» y añade que «jamás lo hubieran usado los humanistas del primer Cuatrocientos, ni lo emplearon apenas los posteriores: al llegar a la escuela -prosigue este investigador - los studia humanitatis se banalizaron en un término zafio y cargado de matices negativos, usado incluso con desdén, "per contemptum"». Véase sobre el particular A. Campana, «The Origin of the Word "humanist"», $J W C I, 9$ (1946), pp. 60-73, P. F. Grendler, «Five Italian Occurrences of "umanista" 1540-1574», RQ, 20 (1967), pp. 317325; P. Brown, «A Significant Sixteenth-Century Use of the Word "umanista"», Modern Language Review; 64 (1969), pp. 567-575; así como las esclarecedoras reflexiones de E. Garin, «Los humanistas y la ciencia», en La revolución cultural del Renacimiento, trad. esp., Barcelona, 1984, 2. ${ }^{\text {a }}$ ed., pp. 257-259, donde se hace alusión a los conocimientos filosóficos y científicos (además de literarios) que estos profesores de humanidades tuvieron.

46 «Lumanesimo bizantino», p. 9.

47 Los rasgos principales del sistema educativo humanista (su oposición a lo medieval —que hay que matizar, sin embargo, en todos los aspectos, como se verá a lo largo de estas páginas-), pueden verse en Garin, La educación en Europa, 1400-1600. Problemas y programas, trad. esp., Barcelona, 1987, así como infinidad de textos en ídem, Il pensiero pedagogico dell'Umanesimo, Florencia, 1958. Es de mucho interés igualmente P. F. Grendler, Schooling in Renaissance Italy: Literacy and Learning, 1300-1600, Baltimore-Londres, 1991, así como el estudio de A. Grafton, «L'umanista come lettore», en Cavallo y Chartier (eds.), Storia della lettura, pp. 199-242.

48 Los ejemplos de veneración por lo antiguo en época temprana no son escasos: «cuando en 1283 se descubrió una hermosa arca de fecha venerable (en realidad cristiana) - escribe Rico, El sueño, p. 29--, Lovato Lovati no dudó en identificarla como el sepulcro del troyano Antenor, el mítico fundador de la ciudad, y en ennoblecer la elegante glorieta en que fue colocada con un epitafio en que las reminiscencias de Virgilio y Ovidio se conjugaban con ecos de Tito Livio».

49 Véase, a este propósito, Buck, Die Rezeption der Antike, p. 19.

50 Umanesimo e teologia, trad. it., Milán, 1958, pp. 29 y 72, n. 25, citado por Impellizzeri, «L' umanesimo bizantino». Con agudeza, E. Panofsky, Renacimiento y renacimientos en el arte occidental, trad. esp., Madrid, 1985, 5. ed., p. 43, observa que Petrarca «era demasiado buen cristiano para no darse cuenta, al menos en ciertos momentos, de que su concepción de la Antigüedad clásica como una edad de "pura claridad", y de la era siguiente a la conversión de Constantino como una 
retornos ${ }^{51}$ a la Antigüedad clásica, de los que, ni en lo referente a los detalles históricos o de contenido — pese a su evidente interés - ni tampoco a los terminológicos cabe hablar aquí, ${ }^{22}$ los dos conceptos, humanismo y renacimiento, entraron en el vocabulario técnico y común de la pasada centuria ${ }^{53}$ para denotar el gran movimiento cultural de los siglos XIV-XVI. De este movimiento,

edad de tenebrosa ignorancia, equivalía a una inversión completa de los valores establecidos. Pero también estaba demasiado convencido de que "la historia no era otra cosa que alabanza de Roma" para renunciar a su visión. Y al transferir al estado de la cultura intelectual precisamente aquellos términos que los teólogos, los Padres de la Iglesia e incluso la Sagrada Escritura aplicaran al estado del alma (lux y sol frente a nox y tenebrae, "vigilia" frente a "sopor", "visión" frente a "ceguera"), y sostener que los romanos paganos habían vivido en la luz en tanto que los cristianos caminaban en la oscuridad, revolucionó la interpretación de la historia tan radicalmente como Copérnico, doscientos años más tarde, había de revolucionar la interpretación del universo físico». En un orden de cosas parecido, es de interés destacar que J. R. Hale, La Europa del Renacimiento, 1480-1520, trad. esp., Madrid, 1973, p. 324, advierte de que tanto la decadencia de Atenas como la de Roma fue sentida por los humanistas como voluntad de Dios y, a la vez, señala que el hecho de que griegos y romanos no lo supieran «permitía que los que exhumaban y leían sus narraciones consideraran a la antigüedad en función de sus propios términos. El presente se había encontrado, como sucedió, con un alter ego. Aparte de los habitantes de la ciudad celestial de Dios, los hombres podían imaginarse ahora una sociedad parecida a la suya, a la que sólo le faltaba el compás, la imprenta, la pólvora, el Papado y las Américas». Un entusiasmo casi religioso como el de Petrarca tuvo también paralelos más conceptuales pero no menos exagerados por lo apasionados; en 1424, por ejemplo, como leemos en W. Berschin, «Elementi greci nella cultura letteraria medievale», Aevum, 58 (1984), p. 131, Leonardo Bruni escribió a Antonio Loschi que, durante 700 años, no se había tenido el menor conocimiento de la disciplina Graecarum litterarum. Lo que Bruni quería decir -y, aquí seguimos a Garin, La educación en Europa, p. 86- era que, aunque se hubiesen copiado manuscritos y el griego se hubiese seguido enseñando, como de hecho sucedió, «el mundo griego» era todavía terreno desconocido. Es esto algo muy similar a lo que el gran Lorenzo Valla pretendía decir cuando escribió que la Edad Media había ignorado incluso la lengua latina. «Sólo con que se entienda el significado de estas afirmaciones, realmente polémicas, pero sin duda importantes, se puede comprender - escribe Garin - el valor atribuido en el siglo XV a la cultura antigua». Véase también P. Burke, El Renacimiento, trad. esp., Barcelona, 1993, pp. 9-11 y, en concreto, sobre el tópico de la pérdida de los saberes antiguos en otros ámbitos, J. Delumeau, La civilización, p. 101: «El gran Durero mismo declaró que la pintura había estado sumida en la oscuridad y el abandono durante los mil años siguientes a la caída del Imperio romano, hasta que, desde hacía dos siglos, los italianos la sacaron nuevamente a la luz».

51 «In più di un'epoca —-nell'età ellenistica, nell'età augustea, in alcuni secoli della civiltà letteraria bizantina, nell' Umanesimo italiano, nel secolo di Winckelmann e di Goethe-, sia pure con ovvie», nuances, -ha escrito Marcelo Gigante, Classico e mediazione. Contributti alla storia della filologia antica, Roma', 1989, p. 11, corroborando una vez más la omnipresencia de lo clásico a lo largo de la historia — gli antichi costituirono il paradigma, il modello, la misura, il canone della perfezione; sembrò che nulla potesse essere scritto detto o pensato senza una pedante incitazione o una nobile emulazione degli antichi nella letteratura e nelle arti figurative. Para una rápida sistematización de la presencia de lo griego clásico en el Renacimiento bastará con remitir a G. Billanovich, «I primi umanisti e l'Antichità classica», en Bolgar (ed.), Classical Influences, pp. 57-66; A. Buck, «Die antiken Autoren aus der Sicht Dantes und Petrarcas» en Buck (ed.), Die Rezeption der Antike. Zum Problem der Kontinuität zwischen Mittelalter und Renaissance, Hamburgo, 1981, pp. 9-22; y G. Griffiths, «Classical Greece and the Italian Renaissance», en C.G. Thomas (ed.), Paths from Ancient Greece, Leiden, 1988, pp. 92-117. Sobre la visión que el Renacimiento tuvo de la cultura griega antigua puede verse también, en general, P. Burke, «The Renaissance», en K.J. Dover (ed.), Perceptions of the Ancient Greeks, Oxford, 1992, pp. 128-146.

52 Remitimos, en general, tanto para una visión de estos sucesivos «renacimientos» como para las cuestiones terminológicas, a W. Treadgold (ed.), Renaissances before the Renaissance. Cultural Revivals of Late Antiquity and the Middle Ages, Stanford, California, 1984; B. Schimmelpfennig, «Renaissance/Proto-Renaissance, Renovatio/Renewal, Rezeption», en W. Erzgräber (ed.), Kontinuität und Transformation der Antike im Mittelalter, Sigmaringen, 1989, pp. 383-390; y a nuestro artículo «La recepción del mundo clásico y el Renacimiento. Hechos y teorías en torno a la influencia bizantina», en el que trabajamos en la actualidad.

53 Véase, entre otros trabajos, Ch.-O. Carbonell, «L'idée de Renaissance dans l'historiographie du XIXe siècle», en L'idée de Renaissance dans l'Occident moderne (XIVe Colloque de l'Institut de Recherches sur les Civilisations de l'Occident moderne), París, 1986 (= Civilisations, 12), pp. 83-95. A nuestro modo de ver, un libro de gran utilidad como introducción a los problemas de interpretación del fenómeno renacentista sigue siendo el de W. K. Ferguson, The Renaissance in Historical Thought: Five Centuries of Interpretation, Cambridge, Mass., 1948 (hay trad. it.) aunque, como 
que afectó a toda la civilización europea en múltiples ámbitos y con diferente intensidad -incluida España, claro es- ${ }^{54}$ los análisis globales han sido numerosos ${ }^{55}$ y, como ya se ha señalado, no todos coincidentes en los detalles. Un autor como Maravall, por ejemplo, está dispuesto a reconocer la italianidad del humanismo, «cuya exportación va unida con frecuencia a la salida de personajes italianos»; ${ }^{66}$ el Renacimiento, en cambio, no es para él del todo italiano. En efecto, escribe, «algunos elementos hay que reconocer se producen en Italia; pero no grana hasta no expandirse. Aparece en cuanto abarca la vida social entera, y hay aspectos que no se reconocen bien hasta que no fructifican fuera -en Francia, en España, en Inglaterra..., en Polonia».

Visto lo que antecede a propósito de las nociones de humanismo y Renacimiento, volvamos ahora a esos cambios de perspectiva que entre la Edad Media y el Renacimiento tienen lugar en el pensamiento europeo. Según ha escrito, por ejemplo, F. Garrote Pérez, ${ }^{57}$ la discontinuidad relativa (¡la cursiva es nuestra!) con la época anterior y el deseo de descubrir y conectar con la Antigüedad griega y latina es un hecho evidente. Sin embargo, España parece adoptar, para este investigador,

es lógico, ha de ser completado con las nuevas interpretaciones y la bibliografía reciente. Entre la inmensa montaña de escritos sobre el particular hemos utilizado sólo algunos que destacaremos: A. Buck (ed.), Zum Begriff und Problem des Renaissance, Darmstadt, 1969; M. Ciliberto, Il Rinascimento. Storia di un dibattito, Florencia, 1975; Garin, «Interpretaciones del Renacimiento», en Medioevo y Renacimiento. Estudios e investigaciones, trad. esp., Madrid, 1981, pp. 68-81 (no un análisis de las diversas interpretaciones propuestas sino, más bien, una visión personal de un experto en el tema); y D. Hay, «Storici e Rinascimento negli ultimi venticinque anni» en M. Boas Hall et alii, Il Rinascimento. Interpretazioni e Problemi, Bari, 1983, pp. 3-41.

54 Una buena síntesis reciente, en lo que a nuestra patria toca, puede encontrarse en A. Goodman-A. MacKay (eds.), The Impact of Humanism on Western Europe, Londres-Nueva York, 1990. Dedicado a D. Hay, el libro trata de los movimientos reformistas, el pensamiento político, las artes cortesanas, la magia y la ciencia, así como de las manifestaciones concretas de los nuevos tiempos en Italia, Países Bajos, Francia, Alemania, Inglaterra y la península ibérica (esta última en ibídem, pp. 220-258, a cargo de J.N.H. Lawrance). De mucho interés también son O. di Camillo, «Humanism in Spain», en A. Rabil (ed.), Renaissance Humanism. Foundations, Forms, and Legacy II: Humanism beyond Italy, Filadelfia, 1991, pp. 55-108; y Gómez Moreno, España, passim.

55 Entre los muchos trabajos introductorios que ofrecen una perspectiva general del mundo renacentista, y aparte de lo ya indicado, cabe señalar la obra de N. Mann (ed.), Renacimiento. Arte y pensamiento renuevan Europa, trad. esp. Barcelona, 1993. Se trata de uno más de los «Atlas culturales del mundo», con una rica ilustración y abundantes y detallados mapas, a los que acompañan textos de diversos especialistas dirigidos por el director del Warburg Institute de la Universidad de Londres.

56 «La diversificación de modelos del Renacimiento: El Renacimiento español y el Renacimiento francés», Cuadernos Hispanoamericänos, 390 (1982), recogido en Estudios de historia del pensamiento español. Serie segunda: La época del Renacimiento, Madrid, 1984, p. 132. «El humanismo no se da tan sólo con el conocimiento de los clásicos grecolatinos [...] El "humanismo" propiamente tal supone algo más: por lo menos la creencia en que la posesión sabia del latín -y también del griego y aun del hebreo- son la vía para la reforma moral del hombre interior y de la convivencia en la república, conforme a la virtud» (Ibidem, n.7). Fueron los humanistas, añade Maravall, ibídem, p. 150, quienes «al proclamar su admiración por las lenguas clásicas y su atención discipular a la Antigüedad, concibieron a aquéllas como depósito en el que se contenían y se conservaban válidos los saberes específicos sobre las cosas naturales y morales o humanas. Así, ha dicho Francisco Rico que en el prólogo a las Introducciones latinas de Nebrija se nos presenta la Gramática de esta lengua como fundamento para alcanzar todo conocimiento sobre la realidad. A ello hemos de añadir que ese legado, depositado en las lenguas "antiguas", era un contenido sabiamente seleccionado que proporcionaba cuanto de útil para una vida virtuosa y para una posesión de la verdad hacía falta. "Las Introducciones - resume Rico-proponen un mundo nuevo basado sobre la palabra clásica... La plenitud del individuo y de la comunidad empieza con un modesto manual de latín"». [(Remite Maravall a Rico, «Lección y herencia de E.A. de Nebrija», en el vol. colectivo Nebrija a Catalunya, Barcelona, 1981, pp. 12 y 14).

57 Naturaleza y pensamiento en España en los siglos XVI y XVII, Salamanca, 1981, p. 14. 
una postura peculiar, consistente en una clara continuidad cultural, por un lado, y en la pervivencia, a la vez, de los valores recibidos frente a las nuevas influencias, que, en principio, no son descartadas. Lo antiguo y lo moderno se unen, pues, en una simbiosis nueva, eso es cierto, pero se trata de algo un poco distinto de lo que ocurre en el resto de los países europeos, lleno también de posibilidades, empero, en el ámbito del pensamiento hispano. Efectivamente, separada España, por mor de los esfuerzos de la Reconquista, de las inquietudes intelectuales que se fueron afianzando en otros pagos - la idea es de A. Castro, ${ }^{58}$ como recuerda Garrote-, los ideales medievales ${ }^{59}$ permanecen vivos más tiempo en nuestro suelo y un testimonio claro de esto puede ser, por ejemplo, la obra de Felipe de la Torre, ${ }^{60}$ quien, nada menos que en 1556 , seguirá sosteniendo que la justicia y la religión son las dos virtudes de toda república y que el rey castiga a los malos y defiende a los buenos con una autoridad participada de la de Dios, de la cual es vicario en la tierra. Que ya los tiempos no estaban del todo para estas concepciones en Europa es cosa archisabida; pero, además, a nadie se le escapa que estas ideas hacen resonar en nuestros oídos las opiniones que un Eusebio de Cesarea dirigió a su admirado Constantino el Grande o incluso las del diácono Agapeto, de cuyas exhortaciones al emperador Justiniano, compuestas en el s. VI, se hicieron nada menos que dos traducciones al castellano en el s. XVI. ${ }^{61} \mathrm{Y}$, por si esto fuera poco, el pensamiento escolástico, combatido en muchos lugares, lo cierto es que se atrinchera más adelante en nuestro país y brilla reformado por una pléyade de pensadores de gran interés, como son Melchor Cano, Francisco de Vitoria, Francisco Suárez y otros muchos. Por supuesto que Aristóteles estuvo en el punto de mira de los críticos también en España, «pero el sesgo tomado por el pensamiento español era un claro eclecticismo» ${ }^{62}$ de su sistema y el platónico. ${ }^{63}$ En resumidas cuentas, para Garrote y otros con él,

58 Teresa la santa y otros ensayos, Madrid, 1972, p. 16.

59 Para la pervivencia en nuestra patria, de otra parte, de un modo de vida apegado a las características tardoantiguas, «especialmente ricas», como consecuencia de una "paralización conservadora» ("la "clave mozárabe" de nuestro destino histórico»), véase Maravall, «El pensamiento político español del año 400 al $1300 »$, en Cahiers d'Histoire Mondiale, 4 (1958), recogido en Estudios de Historia del pensamiento español, I, pp. 40 y ss.

60 Institución de un Rey. Christiano, colegida principalmente de la Santa Escritura y de los sagrados Doctores, Amberes, 1556; la obra es citada por Garrote, que, a su vez, remite a Maravall, La oposición política bajo los Austrias, Madrid, 1972, p. 82.

61 Se trata de las traducciones de Diego Gracián, Preceptos y Reglas de Ysocrates Atheniense Philosopho y. Orador clarissimo, que tractan de la governación del Reyno, donde muestra qual conuiene ser el Rey para con sus subditos y los subditos para con su Rey poniéndoles delante leyes iustissimas, que guarden. Instruçión de Agapeto, diacono, del oficio y cargo del Rej; al Emperador justiniano. Traduzido de lengua Griega en Castellana [...], Valladolid, 1551; y de Cristóbal Mosquera de Figueroa, Comentario en breve compendio de disciplina militar; en que se escrive la jornada de las islas de los Açores, Madrid 1596; puede verse sobre ellas Bravo García, «Dos traducciones de Agapeto impresas en el siglo XVI», Revista de Filologia Románica, 2 (1984), pp. 225-232.

62 Garrote, Naturaleza y pensamiento, p. 18.

63 La gran armonía entre aristotelismo y platonismo que nos es dado observar en el pensamiento español de la época que analizamos - y que cabría rastrear ya en el Medievo- no debe hacernos olvidar, ha señalado Garrote, ibídem, p. 71, que el esquema fundamental de la teoría de la naturaleza radicaba en el tomismo aristotélico y, por ello, en la razón. Esta teoría natural se basaba además en la relación del hombre con la naturaleza, que, en el fondo, era considerada como un mecanismo dotado de una organización y de leyes propias. El aristotelismo que subyace a esta concepción corre el riesgo de desvanecerse, sin embargo, y de llevarnos a las fuentes platónicas en tanto en cuanto al considerar a la naturaleza como un organismo vivo, "preparamos el camino para la magia y la astrología», concepción netamente platónica al decir de Garrote, ibídem, p. 73. «La cosmología de muchos platonistas renacentistas y filósofos de la naturaleza del XVI - ha 
pese a lo que pueda parecer, el estado cultural de nuestro siglo XVI seguía siendo «eminentemente medieval». Como una muestra palmaria de ello, señala Garrote que «la cosmología estaba sin renovar, como se deduce de los comentarios de Villalobos ${ }^{64}$ al segundo libro de Plinio. Para Villalobos, como para el resto de los pensadores,» - continúa este investigador- ${ }^{65}$ el concepto general del mundo es tal como lo expone doña Oliva Sabuco de Nantes de Barrera [en su Nueva filosofía de la naturaleza del hombre ${ }^{66}$ en los siguientes términos: "Pues imagine (señor Veronio) un huevo de avestruz, grande, redondo, con tres claras y once cáscaras. En este huevo la yema pequeña redonda es la tierra, y la primera clara pequeña que la cerca es el agua (que todo lo cerca), y la segunda clara mayor es el aire y la tercera, muy más mayor, es el fuego. La primera cáscara es el primer cielo, y la segunda es el segundo cielo, etc.; y estos cuatro elementos son la materia de todas las cosas de este mundo, y de esta manera toman sus varias formas todos los mixtos que tienen los cuerpos[...]" Lo cual supone» —en palabras del mismo Garrote- «que aún no se había admitido el heliocentrismo y se seguía con fidelidad el viejo sistema de Tolomeo. Por esta razón,» «no puede sorprendernos encontrar a hombres ilustres en el siglo XVI como Luis de León, Luis de Granada y hasta el científico Valles, aceptando que la tierra estaba estacionada, suspendida en el espacio».

b) No nos interesa rastrear en profundidad este relativo atraso científico $0^{67}$ o cultural que, para algunos, hunde sus raíces directamente en el s. XV y más allá, aunque, para otros, debe interpretarse más bien, simplemente, como una manifestación de ese eclecticismo entre lo antiguo y lo moderno, que viene a caracterizar en parte a nuestros siglos XV y XVI; lo que sí haremos es mencionar de paso y a guisa de ejemplo ilustrativo de una cierta manera de pensar entre los intérpretes modernos, que la obra que precisamente sirvió a Ernst Curtius ${ }^{68}$ para caracterizar el retraso cultu-

escrito de otra parte P. O. Kristeller, «La filosofía renacentista y la tradición medieval», artículo de 1966 recogido en $E l$ pensamiento renacentista, p. 173- planteaba un universo animado por un alma universal y unido por ocultas fuerzas de afinidad, que los sabios eruditos y con un adiestramiento adecuado podían descubrir y dirigir». En general, sobre lo que constituye en el Renacimiento la mentalidad «científica» y la «mágica» pueden verse los trabajos de diversos autores y la introducción del libro de B. Vickers (comp.), Mentalidades ocultas y cientificas en el Renacimiento, trad. esp., Madrid, 1990; y W. Schumacher, The Occult Sciences in the Renaissance. A Study in Intellectual Patterns, Berkeley-Los ÁngelesLondres, 1972.

64 Se refiere Garrote a Francisco López de Villalobos, Algunas obras, Madrid, Bibl. Esp., 1886, p. 148; véase sobre este autor López Piñero, s.v., en el Diccionario histórico de la ciencia, I, pp. 543-545.

65 Naturaleza y pensamiento, p. 19

66 Véase, más reciente que la ed. citada por Garrote, la de A. Martínez Tomé (Madrid, 1981).

67 Las opiniones de doña Oliva (de su padre, mejor dicho, como es bien sabido) harán pensar, sin duda, al lector en las ideas del molinero friulano Domenico Scandella, conocido como Menocchio, que fue quemado por el Santo Oficio, y cuya vida de lecturas ha descrito de forma magistral C. Ginzburg, El queso y los gusanos. El cosmos, según un molinero del siglo XVI, trad. esp., Madrid 1986. Existen diferencias, claro es, pero es la simplicidad de la exposición de doña Oliva la que nos mueve a señalar un cierto parecido. Por otro lado, según ha notado M. Gendreau-Massaloux, «Humanisme et mathématiques: Quevedo lecteur de Théodose de Tripoli», en A. Redondo (ed.), L'Humanisme dans les lettres espagnoles (XIXe Colloque International d'Études Humanistes, Tours 1976), París, 1979, p. 312, los escritos españoles, desde la Celestina hasta Calderón, «expriment l'adhésion à une représentation du monde physique directement issue du système de Ptolémée». Alejo Venegas, un autor que tomaremos en consideración en la segunda parte de nuestro trabajo, en su Agonía del tránsito de la muerte (ed. de la NBAE, 16, 308a), por ejemplo, nos ofrece una imagen que, según Gendreau-Massaloux, implica también a las claras la creencia en un universo geocéntrico: «Los orbes celestes son / como cascos de cebolla».

68 Literatura europea y Edad Media latina, II, trad. esp., Madrid-Méjico, D.F., 1984; p. 756 (es reimpr.) 
ral de nuestra patria ya en el s. XV fue la Visión delectable de la vida bienaventurada de Alfonso de la Torre, libro escrito en 1440, impreso posteriormente (1480), con tres ediciones en el s. XV, otras tres en el XVI, dos en el XVII y traducciones al catalán a finales del XV y al italiano a mediados del XVI. Para Curtius, nos hallamos ante un libro que, pese a estar escrito en los comedios del s. XV, todavía pudo «hallar lectores en España hasta entrado el siglo XVII, a pesar de que se desentiende casi por completo de cuanto produjo la literatura europea en el terreno de la ciencia y de la filosofía a partir de 1200: no sólo del tomismo, sino también del humanismo y de los albores del Renacimiento italiano». Tanto M. ${ }^{a}$. Rosa Lida de Malkiel como W. Crawford, S. Farcasiu y otros especialistas se han opuesto a esta opinión de Curtius, insistiendo en las especiales características de esta obra alegórica, en sus verdaderas fuentes (por supuesto, entre otras muchas, Aristóteles) ${ }^{69}$ y en otros aspectos, como recientemente ha sintetizado C. Salinas Espinosa. ${ }^{70}$ En opinión de esta investigadora, como también para otros, el s. XV no tenía por qué ser obligatoriamente «humanista» y su rechazo a este modelo cultural importado de Italia no debe servirnos como base para un juicio negativo; la obra de de la Torre, en suma, es «una muestra certera de esa original mezcla de valores claramente medievales con rasgos modernos» que nos refleja muy claramente «la convivencia de dos mundos y dos épocas que por distintas se suelen considerar irreconciliables. Si entendemos la historia como un proceso y no como un cambio súbito de épocas - prosigue esta misma investigadora podremos comprender mejor esta sabia alternancia de lo antiguo y lo moderno, que, si no humanista, no es tampoco signo de retraso cultural». ${ }^{71} \mathrm{Y}$, si hemos de proseguir con nuestra descripción de la época a grandes pinceladas, sin perder de vista lo que acabamos de decir a propósito de ese especial eclecticismo español (que, por otro lado, no es del todo desconocido en el resto de Europa), no debemos dejar de recordar que Garrote Pérez ${ }^{72}$, anticipándose en otro lugar a sus opiniones ya comentadas y a lo que es el meollo del trabajo de Salinas Espinosa, ha escrito que «la cultura española renacentista es en parte idéntica al Renacimiento italiano y en parte distinta. Por tanto - concluye-, si queremos comprender la literatura clásica española, será necesario hacer una elección: o enfocarla desde una perspectiva exclusivamente renacentista, como han hecho varios críticos (los cuales han llegado a la conclusión de que no existe Renacimiento en España) ${ }^{73}$ 0 , para que no resulte un hecho desconcertante, acercarse a ella desde una continuidad ideológica, renovada por las nuevas ideas renacentistas [...] La raíz de nuestro pensamiento renacentista hay que buscarla en la continuidad de la cultura medieval, interpretada ahora a la luz de la modernidad, con lo cual no pierde su entronque con el pasado». La formulación del problema nos parece acertada.

c) Tampoco se aleja mucho de la realidad, aunque la contempla desde otra perspectiva, el análisis que de la oposición entre Renacimiento y escolástica en nuestras tierras ha llevado a cabo

69 Para la utilización, en esta y otras obras, de una sistematización basada en las categorías aristotélicas véase, por ejemplo, W. Melczer, «Juan de Mal Lara et l'école humaniste de Séville», en Redondo (ed.), L'Humanisme, pp. 95 y ss.

70 «Dos obras del siglo XV: Humanismo versus retraso cultural», en J.M. ${ }^{a}$ Maestre Maestre y J. Pascual Barea (coord.), Humanismo y pervivencia del mundo clásico. I. 2 (Actas del I Simposio sobre humanismo y pervivencia del mundo clásico. Alcañiz [...] 1990), Cádiz, 1993, pp. 993-1002.

71 Ibidem, p. 1002.

72 La naturaleza en el pensamiento de Cervantes, Salamanca, 1979, p. 13.

73 Remitimos a la bibliografía ya mencionada en n. 42. 
Joseph Pérez no hace mucho ${ }^{74}$ y las importantes reflexiones que sobre este mismo tema debemos a José Antonio Maravall en varios de sus numerosos trabajos. Para Pérez, la escolástica, sistema de ideas que engloba una teología, una filosofía y el uso de un lenguaje técnico muy sofisticado, se fue convirtiendo poco a poco en una pura especulación teórica, sin que de ella pudieran deducirse normas éticas. Frente a esta perversión o desviación, los humanistas protestaron en buena parte afirmand $0^{75}$ que «el cristianismo no es sólo ni ante todo un sistema de ideas sino la manifestación de una Persona; no es una pura especulación, sino vida, actitudes morales, conducta práctica»; de tal manera que el ideal de una santa necedad, ${ }^{76}$ partidaria más de vivir que de argumentar, lo que hará será apostar por las líneas de la Imitación de Cristo, el famoso manual de Tomás de Kempis, en vez de por las sofisterías de los tardíos escolásticos. Pero no perdamos de vista que esta actitud va más allá de lo puramente religioso; «La escolástica»—en opinión de Pérez—77 supone también «una profesionalización del saber; la ciencia está reservada a una élite de profesores, clérigos en su mayor parte. Frente a esta pretensión -prosigue-, los humanistas ponen en tela de juicio la autoridad de los expertos: exigen pruebas, discusión abierta, libre examen, en una palabra crítica o irrespeto ante la autoridad y la tradición; piden cuentas, exigen explicaciones, como lo hizo Lorenzo Valla, por ejemplo, al reexaminar la donación de Constantino. ${ }^{78} \mathrm{El}$ humanismo es ante todo - concluye-, cultura general contra excesiva especialización, contra la profesionalidad exagerada». Es la reacción frente al tecnicismo y la especialización exagerada, pues, la que, para Pérez, lleva a una oposición abierta frente a las auctoritates.

d) No muy lejos de estas últimas ideas se alinean las teorías de José Antonio Maravall, aunque su pensamiento toma como punto de partida un análisis profundo del concepto de saber y de la sociedad medieval por entero; como una certificación casi de la concepción inmovilista propia

74 «Renacimiento y escolástica» ya citado; véase del mismo autor «Humanismo y escolástica», Cuadernos Hispanoamericanos, 334 (1978), pp. 28-39.

75 «Renacimiento y escolástica», p. 10.

76 Remitiendo a M. Andrés, La teología española en el siglo XVI, I, Madrid, 1976, p. 92, llama Pérez la atención sobre el franciscano Pedro de Villacreces, quien, en el s. XV, puso especial interés más en los santos necios que en los santos letrados y letras, llegando a inspirar a sus discípulos - en un deseo bien conocido que aflora aquí y allá desde los primeros tiempos del cristianisno- el aborrecimiento del estudio de las letras. Los testimonios a propósito de que sólo la fe y una vida simple, alejadas de la inútil ciencia, pueden salvar nuestra alma no son escasos en la Edad Media y R. W. Southern, Western Society and the Church in the Middle Ages, Harmondsworth, 1980, pp. 334 y ss., ha estudiado ese tema. Recordemos de otra parte que ya en los exempla medievales (véase, por ejemplo, la historia de S. Pioterio y la monja $[P L$ 73, 984 y 1140; Klapper $\$ 197$, p. 401 y más en concreto R. Ayerbe-Chaux, El conde Lucanor: Material tradicional y originalidad creadora, Madrid, 1975, pp. 202 y ss.]). aparece la persona ignorante, despreciada, que atesora en sí el mérito del verdadero santo; el material relacionado con el «santo loco por Cristo» (que se finge loco pero que no lo es) es muy abundante en la literatura de Bizancio y también en el mundo eslavo (véase, por ejemplo, A. Bravo García, «El héroe bizantino» en la obra colectiva Los héroes medievales; [= Cuadernos del CEMYR 1], La Laguna, 1994, pp. 101-142; y, para el Medievo, algunas observaciones de interés pueden encontrarse en el estudio de J.-M. Fritz, Le discours du fou au Moyen Âge. XIle-XIIle siècles, París, 1992, pp. 282 y ss.).

77 «Renaciniento y escolástica», p. 11.

78 De todos modos, recordemos nosotros, el estudio sobre la donación de Valla parece tener también otras causas; se trata, para algunos, de un verdadero «"acto de guerra", orientado por precisas instrucciones de Alfonso [el Magnánimo], en la larga campaña que desde años atrás mantenía [...] con Eugenio IV, y en el mismo momento en que el Pontífice decidía apoyar militarmente a René de Anjou». Así lo escribe, al menos, F. Rico, El sueño, p. 56, trayendo a colación el estudio de M. Fois, Il pensiero cristiano di Lorenzo Valla nel quadro storico-culturale del suo ambiente, Roma, 1966. 
de la sociedad del Medievo, tanto Juan García de Castrogeriz en su Glosa castellana al regimiento de príncipes, como Rodrigo Sánchez de Arévalo en su Suma de la política, echan mano de la metáfora «cuerpo» aplicada a la ciudad o sociedad civil; de fuente clásica, la imagen, a juicio de Maravall, ${ }^{79}$ «lleva tras de sí toda la justificación orgánica del naturalismo aristotélico y a la vez del orden trascendente de la teología», aunque comparte en la misma época, finales del s. XIV y primeras décadas del XV, influencias paulinas. «Mucho antes, pues, de que Suárez se sirviera de la doctrina del corpus mysticum para construir la figura soberana suficiente y perfecta de su orden, de la comunidad política, de lo que en su latín llama ya Suárez con el término moderno de Status; mucho antes de que Erasmo, en el campo de la Iglesia, renovara la inagotada fuerza de la imagen paulina, en España» puede decirse que ya era común la expresión, que unía, precisa Maravall, el «organicismo político de procedencia antigua, con la moderna aplicación a la Iglesia» de la conocida fórmula de S. Pablo. No obstante, el dinamismo que la imagen transmite (se trata de una entidad que no es otra cosa que concertación de partes móviles en una unidad que, al tiempo, también lo es) queda anulado, en cierto modo, en razón de lo que los sociólogos han venido observando acerca del marcado carácter estático de la sociedad medieval. En efecto, «las esferas de mayor importancia en el desenvolvimiento de la vida de un grupo acusan en el medievo esa tendencia a la inmovilidad que caracteriza a una sociedad tradicional». ${ }^{80}$ Todo, pues: la moral, el derecho, la economía, la ciencia, «los sistemas de adoctrinar sobre la conducta recta, los procedimientos de establecer y declarar el derecho [...]» ... absolutamente todo, «muestra la general tendencia a la repetición de modelos y normas conservados de tiempo atrás, o, por lo menos, cuya vigencia se justifica porque se cree socialmente en el uso ancestral de los mismos». ${ }^{81}$ La conservación y la transmisión de lo recibido, de lo «sabido» a través de nuestros antepasados, evidentemente, lleva a concebir el saber en general como algo estático, fijado, regulado, codificado, al que se accede de manera también determinada, es decir, yendo a buscarlo, a recogerlo a sus fuentes sin necesidad de una verdadera investigación sobre la realidad. Este mecanismo, por lo tanto, no pretende «ensanchar o extender los dominios del conocimiento humano. Éstos estan dados de una vez para siempre, tan acabados, definitivos y delimitados como el universo mismo». ${ }^{82}$ La visión estática de la actividad

79 «La idea de cuerpo místico en España antes de Erasmo», Boletín de la Cátedra de Derecho Político de la Universidad de Salamanca, 10-12 (1956), recogido en Estudios de historia del pensamiento español, I, pp. 187-188.

80 Maravall, «La concepción del saber en una sociedad tradicional», Cuadernos Hispanoamericanos, 197 y 198 (1966), recogido en Estudios de historia del pensamiento español I, pp. 203-204.

81 Trae aquí a colación Maravall la opinión de Le Goff, La Civilisation de l'Occident médiéval, París, 1964, p. 399 (hay trad. esp.), de que en estas condiciones, rige una «técnica de la repetición que se traduce en la vida intelectual y espiritual por esa voluntad de abolir el tiempo y el cambio»; viene a ser, de otra parte, algo parecido a lo que A. von Martin, Sociología del Renacimiento, trad. esp., Méjico, D.F., 1988, 11. ${ }^{a}$ reimpr., passim, también citado por Maravall, describe con precisión: «En la Edad Media, - escribe Maravall — todo, economía y ciencia, se mantenía dentro de sus límites, porque se trataba de una situación relativamente inmóvil en la que tanto la ciencia como la economía tenían que cubrir una necesidad fijada y ya conocida». La comparación con la Sociología de la cultura medieval, trad. esp., Madrid, 1970, 2. ed., también de von Martin, resulta interesante.

82 Maravall, «La concepción del saber», p. 211. 
económica que los medievales tenían, ${ }^{83}$ en definitiva, estaba también ligada íntimamente a su concepción de la cultura, los límites fijados a las aspiraciones humanas y, por ende, a ciertos aspectos de esa idea del estatismo y limitación del saber a que se ha hecho referencia. «La dignidad propia de la filosofía, pensó Dante, se deriva ${ }^{84}$ del hecho de que la actividad intelectual "se detiene en un punto previamente determinado", permitiendo así a la mente humana descansar en posesión de la sabiduría plena y en la tranquila contemplación de lo divino». Sin embargo, no es así como pensará Petrarca medio siglo después - justamente el límite teórico que tradicionalmente parece separar a la Edad Media del Renacimiento- ni como creerán otros muchos en tierras españolas; para el poeta de Arezzo, en concreto, que se opone en redondo a la concepción medieval, «la naturaleza de la sabiduría verdadera» era, por el contrario, «el progreso ilimitado de la mente - una sed inagotable de conocimientos. La codicia debe tener sus límites fijos, escribió en una de sus epístolas recordando una máxima de Séneca. Pero con respecto a la cultura y al aprendizaje», las cosas no son ni mucho menos así, aunque esto no quiere decir, por supuesto, que Petrarca fuese por completo ya un «moderno».

Una situación como la que acabamos de describir, pese a que experimenta algunos cambios desde el siglo XII al XV, cuando precisamente — como se verá- las críticas se ensañan con algunos aspectos de aquélla, se conservará, sin embargo, más o menos igual. El acceso a ese saber «pretendidamente perenne» no necesitará investigación sino sólo comunicación ${ }^{85}$ y, mediante los poderosos medios puestos al alcance de estas sociedades tradicionales, los florilegios ya aludidos en estas páginas, las sumas, etc., se conseguirá el vehículo adecuado con el que colaborará la retórica, que se aplicará a expresar ese saber, adecuadamente también, sirviéndose de diversos medios entre

83 Véanse las reflexiones de von Martin, Sociología del Renacimiento, p. 40, a propósito de la actividad económica, mucho más abierta, del Renacimiento y su influencia en el nuevo modelo de conocimiento de la naturaleza. De todas formas, pese a lo atractivo de tales interpretaciones, se han levantado no pocas críticas contra ellas provenientes la mayoría del campo de la Historia de la Ciencia. En relación a la industria, nos dice E. J. Dijksterhuis, Il meccanicismo e l'imagine del mondo dai presocratici a Newton, trad. it., Milán, 1971, pp. 320 y ss.: «si ritiene che la divisione del lavoro in un numero di manipolazioni semplici, che potevano essere eseguite senza un lungo addestramento precedente e che dovevano essere considerati come equivalenti, abbia portato al concetto di lavoro sociale omogeneo astratto, e si pensa che la pratica di calcolare la retribuzione sulla base di simili astratte unità di lavoro abbia indotto gli uomini ad applicare lo stesso schema mentale alla natura. E secondo Simmel fu la nuova economia monetaria dell' incipiente capitalismo quella che diede vita a un"interpretazione del cosmo matematicamente rigorosa». Se opone también este historiador de la ciencia, en concreto, a estas y otras opiniones sostenidas por von Martin, que pretende explicar la autocracia del concepto de ley natural y el nacimiento de una mecánica racional por medio de los cambios sociales, en especial la sustitución de la nobleza de sangre y de la pertenencia a la jerarquía eclesiástica por otras fuerzas sociales dominantes, como la aristocracia del dinero y la inteligencia. Si bien desde el estricto punto de vista que considera «objetivamente» el nacimiento de una «nueva» ciencia (con una metodología notablemente mejorada que, claramente, se basa en los últimos desarrollos medievales del aristotelismo), nada parece tener que ver, en principio (y para algunos), este trasfondo social renacentista y sus cambios con el origen de la actividad investigadora, no olvidemos, sin embargo, que, en lo que toca a la época antigua, los estudios que relacionan el vocabulario técnico político griego con el aparato conceptual de la medicina, bien conocidos de los helenistas, han dado excelentes resultados; véase, por ejemplo, J.P. Vernat, Les origines de la pensée grecque, París, 1969 , 2. ${ }^{a}$ ed., pp. 124-125. El análisis, si no aplaudido por todos, es, al menos, muy atractivo y no parece tan descabellado traerlo aquí a colación.

84 Citamos a H. Baron, «Una interpretación sociológica del primer Renacimiento florentino», trabajo de 1938, recogido en En busca del Humanismo civico, p. 290.

85 Maravall, «La concepción del saber», p. 213. 
los que destacan los exempla. ${ }^{86}$ Pero el cambio se ve venir, avanza poco a poco y llega sin sorprendernos; las transformaciones sociales especialmente, las nuevas modas intelectuales que con éstas se hallan conexionadas, la subsiguiente apertura, progresiva, al terreno de la «realidad» o la «experiencia», los «nuevos tiempos», en definitiva, ${ }^{87}$ harán, entre otras cosas, que el exemplum medieval vaya perdiendo su primitivo valor como generador de auténtica sabiduría (tanto en el terreno moral como en otros). ${ }^{88}$ «Del uso de "fablilla" y de "figuras" protesta, ya en nuestro siglo

$86 \mathrm{Ni}$ que decir tiene que, puesto que la acusación principal de Juan Luis Vives contra el Medievo fue «precisamente su espantosa tergiversación de la cultura antigua» (véase C.G. Noreña, Juan Luis Vives, trad. esp., Madrid, 1978, p. 192), este humanista español se extenderá en el proceso de confusión, daño, tergiversación de obras y manuscritos, amén de señalar, como estudia Noreña, la fatal consecuencia de que, merced a este proceder de siglos, el hombre medieval acabó por perder «toda esperanza de obtener una visión orgánica del proceso histórico. En lugar de ello, se sentía satisfecho con un sinfín de colecciones de aforismos sueltos, citas fuera de contexto o sustrato histórico, compendios superficiales de destreza práctica o puros ríos de verborrea completamente irrelevantes para la vida. De aquí arranca la pasión medieval por los léxicos, manuales, enciclopedias, abecedarios, vademécums, diccionarios, thesauri, catenae, florilegia y cosas semejantes». «¿Quién puede penetrar en el sentido de los autores — nos dirá Vives en el De disciplinis I,1,8-, desposeído de sus soportes y sus tentáculos, de sus antecedentes y consiguientes?». La crítica al bagaje que rodeaba al saber medieval está aquí expresada sin paliativos.

87 Un proceso como éste, que aquí sólo enunciamos de manera muy sucinta, ha sido objeto de cuidadosa reflexión por parte de algunos autores. Exclusivamente desde un punto de vista sociológico, vale la pena reflejar, sin embargo, algún que otro hito de las especulaciones de von Martin. Para él, una creencia típicamente burguesa y urbana es la de que todo puede «hacerse» con el dominio de una técnica racional, lo cual se opone a la mentalidad feudal y religiosa del Medievo; de otra parte, la consideración como autónomas de las que durante la Edad Media habían sido consideradas como causae secundae en la naturaleza (subordinadas entonces férreamente a la causa primaria) debe también considerarse ahora como «el reflejo ideológico del movimiento de emancipación de la burguesía. Este sacudimiento de la tutela clerical aclara von Martin, Sociología del Renacimiento, p. 39-, este sesgo ideológico, constituye una de las armas que más tarde emplearán el ingeniero y el técnico burgués para finalidades prácticas [...] Esta secularización de la mentalidad burguesa» —en definitiva—se funda para este investigador «en la experiencia práctica, bien se trate de pensar según las categorías de una técnica científico-natural, como hace Leonardo, o bien de una técnica política, como hace Maquiavelo». Por lo que toca a la escolástica y la mística, von Martin, Sociología de la cultura medieval, pp. 119-120, afirma de forma paralela que «expresan tan sólo dos aspectos de un espíritu que sociológicamente brota de la misma fuente burguesa y urbana: el aspecto intelectual y el emocional» y precisa que «tanto la racionalidad como la tierna emotividad eran extrañas à la cultura anterior a la ascensión de la burguesía urbana», afirmación esta última que, a su modo de ver, se compadece perfectamente (aunque no se explica) con su opinión de que «la manera de ser medieval» es «más espontánea y emotiva» (Sociología del Renacimiento, p. 40). Finalmente, su visión de la cuestión de los «universales» sigue el mismo patrón; «el realismo de los universales de la escolástica es la expresión filosófica de la conciencia de que las comunidades supraindividuales en las que se vive, y especialmente la más alta de todas, la Iglesia, constituyen la realidad propia y primaria» (Sociología del Renacimiento, p. 40=. El giro hacia el «nominalismo», en cambio, es el testimonio de una nueva época que lleva hacia los tiempos renacentistas; se trata de «la expresión de la disolución de la conciencia de "comunidad" [Gemeinschaft] en conciencia de "sociedad" [Gesellschaff]. El nominalismo "significa" que el todo procede de la asociación de individuos, que la propia Iglesia es un mero nombre genérico», en otras palabras, que los individuos, contra lo que el pensamiento propiamente medieval quería, no carecen de realidad como seres aislados (fuera de la totalidad social y con anterioridad a ella). Un análisis de este tenor, de manera similar a como sucede con el adoptado por Maravall en relación con las diferencias de concepción del saber en el Medievo y el Renacimiento, dota a las explicaciones de una riqueza conceptual evidente; de todas formas, no todos los estudiosos lo emplean o parecen estar de acuerdo con sus conclusiones. Por otro lado, Maravall, «La diversificación», p. 189, no está del todo a favor de la disolución de los lazos de la «comunidad» y su progreso hacia la «sociedad» (categorías de F. Tönnies) y afirma que «la conciencia robustamente naciente del individuo potenció su incorporación a una nueva forma de comunidad, en virtud, por de pronto, de su carácter más activo y dinámico». (La cursiva es nuestra).

88 «Bajo la influencia del pensamiento que, en el campo de la interpretación y comentario de Aristóteles, se está formando en las universidades [...] una nueva noción de ciencia, la cual no elimina todos los factores sapienciales que venían entrando en la misma, pero, al distinguir entre ciencia de las cosas naturales y ciencias morales, da un paso muy importante en la concepción del saber»; véase Maravall, «La concepción del saber», p. 243. 
$\mathrm{XV}$, Alonso de Palencia - claro que parece que su protesta, en tanto que historiador, se refiere más a los "ejemplos" inventados (esos apólogos de los moralistas medievales), que no a los casos verdaderos y ejemplares de la historia [BAE, t. CXVI, p. 346 y 347]. Por esa misma época, Lorenzo Valla -prosigue Maravall__ ${ }^{89}$ clamará contra el uso de ejemplos en los escritos didácticos. Erasmo empleará contra ellos su ironía. Vives [ya se ha visto claramente en una nota] escribirá contra quienes gustan de ellos [...] Hasta en un sector muy apegado a los recursos de tipo tradicional, como es la predicación, cuando llegue el XVI, Terrones del Caño se opondrá a toda suerte de ejemplos o fábulas, de enigmas y jeroglíficos [Instrucción de predicadores, ed. del P. Olmedo, en Clásicos Castellanos, p. 86]. En su eficacia Pero Mexía [del que, por cierto, algo diremos en la segunda parte de este estudio] tampoco cree más que cuando se dirigen a entendimientos bajos [Coloquios o Diálogos, Segunda parte del Coloquio convival, Madrid, CIAP, p. 139]». Lo que va demoliendo esa concepción del saber, su evolución paso a paso, finalmente, ha sido estudiado por Maravall en un trabajo escrito en 1981 y publicado un poco más tarde..$^{90}$ En él se pasa revista a una serie de ideas novedosas de la época; por ejemplo: las críticas contra los privilegios en razón del nacimiento, contra ciertos valores militares, contra los eclesiásticos, la separación entre orden civil y militar - lo que llevará «a la formación de los conceptos autónomos de "ciencia civil" (Enrique de Villena) y de "ciencia política" (Sánchez de Arévalo)», cuya posesión hace expertos, no simplemente sabios o sapientes, según éste, a quienes la estudian, ${ }^{91}$ el valor de la «experiencia» y algunas otras de indudable interés.

Explicaciones del tipo de las que anteceden, con una amplia base sociológica, se apoyan sin duda en la asunción, señalada entre otros por W:K. Ferguson, ${ }^{92}$ de que el cambio social «everywhere precedes cultural change, and that what is new in Renaissance culture, including novel adaptations of inherited traditions, can most readily be explained as the product of a changed social milieu». En efecto, la vuelta a los clásicos del pasado, que con tanto éxito buscaron los humanistas, por ejemplo, puede ser claramente explicada por los cambios en la estructura social que tuvieron lugar, primero, en Italia y, más tarde, en el norte de Europa. Como Ferguson señala en su penetrante estudio, el hecho de que el público se volcase hacia los clásicos es una cuestión que siempre

\section{Ibídem, pp. 228-229.}

90 «El prerrenacimiento del siglo XV», en Actas de la III Academia Literaria Renacentista, Salamanca, 1983, recogido en Estudios de historia del pensamiento español, II, pp. 13-33.

91 Ibídem, p. 28. «La aparición de un pensamiento secularizado - aunque lo sea muy limitadamente- lleva consigo - añade Maravall en una reflexión de gran interés- la precipitación del proceso histórico, característico, quizá como ninguno, de la cultura occidental, en virtud del cual se produjo plena consolidación del concepto de naturaleza como un orden legal, autónomo, inmanente. En este aspecto, en la cuenta del cual no se ha caído hasta tiempos recientes, mucho más que Platón y Petrarca, significan Aristóteles y los averroístas de Padua». Este «orden legal y uniforme», concepto que sustituye a la noción de «regularidad del curso natural» que domina el pensamiento de Tomás de Aquino, por ejemplo, seguirá vivo, terminológicamente, en el pensamiento de Descartes y Galileo y llegará al s. XVIII. Tanto el proceso de conceptualización de la noción de naturaleza que aquí se nos describe por parte de Maravall, como algunas de las manifestaciones literarias que este mismo autor aporta (Alfonso de la Torre, autor ya citado, nos dirá, por ejemplo, que las cosas «no pasan la orden que natura les ha puesto et son uniformes et non mudables en sus operaciones»), merecen un estudio más detenido que el que aquí podemos dedicarles.

92 "The Interpretation of the Renaissance: Suggestions for a Synthesis», Journal of the History of Ideas, 12 (1951), recogido en Kristeller y Wiener (eds.), Renaissance Essays, p. 67. 
ha parecido a los filólogos algo que no necesitaba explicación alguna, algo obvio; sin embargo, para dicho investigador, también este aspecto concreto ha de explicarse: se debe ese interés por los clásicos, simplemente, a que, en su opinión, el estudio concreto del pasado «was perfectly designed to meet the needs of educated, urban laymen, of a society that had ceased to be predominantly either feudal or ecclesiastical, yet had in its own immediate past nothing to draw upon for inspiration but the feudal and ecclesiastical traditions of the Middle Ages». En este mismo sentido, aunque intentando ahora explicar el éxito de las obras políticas antiguas entre los humanistas, Alfred Weber ${ }^{93}$, siguiendo a Burckhardt, señaló que esos estados-ciudades italianos, nacidos de la anarquía tras las luchas entre el papado y el Imperio de los Hohenstaufen, constituían «un complejo o producto sin tradición y sin modelo», y este carácter explica bien la necesidad de imitar la literatura útil para la vida política que la Antigüedad les ofrecía. Del mismo modo, para Ferguson (y en paralelo con las explicaciones que acabamos de ver en Maravall, von Martin y otros) existen otros muchos cambios sociales que pueden dar razón de las nuevas actitudes intelectuales; entre otros -leemos en su trabajo-, aparte de que las ideas circulaban mejor en un ambiente urbano y no básicamente rural, como era el medieval, surgió en aquél un desarrollo comercial, capitalista, que precisaba de una mayor alfabetización en las clases media y superior de las ciudades, mientras que, al tiempo, se permitía a los más encumbrados, gracias a esa bonanza económica, atender sobradamente a las fructíferas labores del mecenazgo.

e) $\mathrm{Si}$, de una manera lo más abreviada posible, deseamos completar ahora lo que ya hemos anticipado sobre nuestro renacimiento (básicamente desde la perspectiva del nacimiento de una actitud contra la auctoritas y de una nueva concepción del saber diferente del de la Edad Media) con una teoría de lo que fue el Renacimiento italiano en lo tocante a estos mismos aspectos, nada mejor, a nuestro juicio, que espigar algunas ideas de entre los numerosos escritos de un reconocido especialista en la materia; nos serviremos en esta ocasión de Paul Oskar Kristeller. Para este investigador alemán afincado en los Estados Unidos ${ }^{94}$ la idea muy simplista de que Aristóteles dominó netamente el pensamiento escolástico medieval, mientras que Platón ${ }^{95}$ fue dueño y señor

93 Historia de la cultura, trad. esp., Méjico, D.F., 1960, 6. ${ }^{2}$ ed., p. 225.

94 Véase sobre su obra, en general, J. Hankins, «Neolatin Philology in North America during the Twentieth Century», en La filologia medievale e umanistica greca e latina nel secolo XX. (Atti del Congresso Int. Roma [...] 1989), Roma, 1993, pp. 973-977.

95 Para los nombres clave del platonismo en Italia véase Kristeller, «El platonismo renacentista», artículo de 1955 , recogido en El pensamiento renacentista, pp. 82 y ss., con muy interesantes reflexiones sobre el aspecto «cuantitativo» del pensamiento platónico en oposición al «cualitativo» aristotélico (ibídem, pp. 89 y ss.); no es nada raro, concluye el autor, «que algunos fundadores de la física moderna [Kepler; Galileo] se sintieran atraídos por este rasgo del platonismo». Véase también, del mismo Kristeller, «La tradición aristotélica», trabajo de 1955, recogido en El pensamiento renacentista, p. 71, y «La filosofía renacentista y la tradición medieval», trabajo de 1966, recogido en El pensamiento renacentista: p. 176: Para M. Dascal, «Lenguaje y conocimiento en la filosofía moderna», en E. de Olaso (ed.), Del Renacimiento a la Ilustración. (Enciclopedia Iberamericana de Filosofía, 6), Valladolid, 1994, p. 23, «la crisis de la ciencia aristotélica a finales del Renacimiento se manifiesta, entre otras cosas, en la insatisfacción con sus explicaciones puramente cualitativas, en términos de causas finales, tendencias de los cuerpos a llegar a sus lugares naturales, etc. Todo eso se percibe ya como pura manipulación verbal [...] Hay que reemplazar esas "explicaciones" por leyes cuantitativas rigurosas, y para eso hay que elaborar el lenguaje matemático adecuado». Más información en torno a estos avances, tanto en el ámbito de la cosmología como en el de la física, puede verse en F. Yates, «Shakespeare y la tradición platónica», artículo publicado originariamente en 1942 y recogido en Ensayos reunidos. II. Renacimiento y Reforma: La contribución italiana, trad. esp., 
en las concepciones renacentistas, no es más que una «fórmula [...] sencilla y placentera» que, por supuesto, ya no se tiene en pie. «Sabemos ahora - ha escrito- ${ }^{96}$ que durante la Edad Media hubo una corriente de platonismo más o menos constante ${ }^{97}$ y que, por otro lado, la escuela aristotélica siguió siendo pujante y muy fuerte durante el siglo XVI y que, incluso, fue en ese período cuando pasó por algunas de sus etapas más características». De hecho, es necesario tener siempre presente, al enfrentarse con la aparición del antiaristotelismo del s. XVI, que, en primer lugar, «después de una temprana aparición en Salerno y en Nápoles, la filosofía aristotélica se estableció firmemente por primera vez en Bolonia y en otras universidades italianas hacia finales del siglo XIII; es decir, - como escribe Kristeller ${ }^{98}$ y nosotros subrayamos - al tiempo que las primeras señales de estudio de los clásicos latinos comenzaron a anunciar el próximo surgimiento del humanismo italiano. Simultáneamente con el humanismo, el aristotelismo italiano se desarrolló sin pausa a lo largo del siglo XIV, sujeto a la influencia de París y de Oxford $;{ }^{99}$ en el siglo XV se hizo más independiente y productivo, y consiguió su máximo desarrollo en el siglo XVI y principios del XVII,

Méjico, D.F., 1981, pp. 262-279; L.M. Krauss, La quinta esencia, trad. esp., Madrid, 1992, pp. 23-46; y lo que decimos en nuestro «La recepción del mundo clásico» ya citado. Por lo que se refiere a España, tampoco escasean las paradojas: «En el jugoso y un tanto inocente humanismo del siglo XII, Platón» -i y no al revés!, ha escrito J. Antonio Maravall, «La estimación de Sócrates y de los sabios clásicos», p. 297- es quien «prima sobre Aristóteles en tanto que filósofo, mientras que la fama de este último es más bien de dialéctico y hábil disputador. Muy a comienzos del XIII, todavía el ya conocido canciller Diego de Campos [Planeta, ed. de P.M. Alonso, Madrid, 1943, p. 169] los junta y compara con este pareado: "vel cum Platone phylosophantem, / vel cum Arystotile disputantem" "

96 «El platonismo bizantino y el occidental en el siglo $\mathrm{XV}$ », artículo publicado en 1966 y recogido en El pensamiento renacentista, p. 207.

97 Coinciden con Kristeller otros muchos investigadores; es sólo a partir de la segunda mitad del s. XIII cuando puede decirse con toda propiedad que la filosofía medieval está dominada por Aristóteles; e incluso, discutido, su magisterio en cierto modo sigue a lo largo de todo lo que resta del Medievo, ya que, como ha observado A. Koyré, «Aristotelismo y platonismo en la filosofía de la Edad Media», artículo publicado en 1944 y recogido en Estudios de historia del pensamiento científico, trad. esp., Madrid, 1990,10. ${ }^{2}$ ed., p. 12, no se les podía quitar Aristóteles a los profesores sin darles otra cosa a cambio y «hasta Descartes no había nada, absolutamente nada, que darles». Hay que contar, pues, para el XI y el XII, con un platonismo (o neoplatonismo) vivo que, por supuesto, no desaparece «con la llegada triunfal de Aristóteles a las escuelas»; no olvidemos, de otra parte, que el más grande de los aristotélicos cristianos, Sto. Tomás, es contemporáneo de S. Buenaventura, el mayor platónico cristiano. Por supuesto, el aristotelismo medieval no es exactamente el antiguo (tampoco lo es el platonismo), pero no por ello dejarán de oponerse ambas concepciones, incluso violentamente (ibídem, p. 22). Por lo que toca a España, anticipemos que Maravall, «La diversificación», p. 154, llegará a decir que «en nuestro Renacimiento, juntos están en Bernat Metge y juntos siguen en Fox Morcillo tanto Aristóteles como Platón, y juntos están en Erasmo, Vives y Lefebvre d'Étaples». Se hablará de esto más adelante.

98 «La tradición aristotélica», p. 62; véase igualmente «El humanismo y el escolasticismo en el Renacimiento italiano», artículo de 1944, recogido en El pensamiento renacentista, pp. 142 y 147. En este último trabajo, Kristeller concluye: «así pues, tanto el humanismo como el escolasticismo ocupan un lugar importante en la civilización del Renacimiento italiano, sin que ninguno de ellos dé una imagen unificada y sin que ambos, juntos, representen la totalidad de la civilización renacentista. Tal como el humanismo y el escolasticismo coexisten como ramas diferentes de la cultura -prosigue este investigador, señalando un punto que a menudo se olvida-, tenemos otras ramas importantes y acaso hasta más importantes. Pienso en el desarrollo de las bellas artes, en la literatura vernácula, en las ciencias matemáticas, en la religión y en la teología».

99 Conviene señalar, como ha hecho Yates, «Shakespeare», pp. 264-265 -recordémoslo-, que «Oxford no se sometió nunca al aristotelismo tomista tan profundamente como París. Oxford siguió fiel al agustinismo en teología a través de toda la Edad Media, y preservó y desarrolló también las tradiciones platónicas de la Escuela de Chartres después de que habían caído hasta cierto punto en la sombra en Francia debido al desarrollo de las grandes escuelas peripatéticas de París. Por supuesto - matiza esta investigadora muy adecuadamente-, el aristotelismo florece en Oxford como en todas partes durante ese período, pero está modificado por una supervivencia particularmente fuerte del platonismo». 
siendo ejemplo de ello pensadores relativamente conocidos como Pomponazzi, Zabarella y Cremonini. En otras palabras, - viene a resumir Kristeller- en lo que a Italia toca, el escolasticismo aristotélico, justo como el humanismo clásico -i por mucho que les pese a no pocos investigadores que simplifican la cuestión de manera muy poco ajustada a la realidad!, añadiríamos nosotros- es ante todo un fenómeno del Renacimiento, cuyas raíces primeras pueden ser seguidas en un desarrollo continuo hasta la fase última de la Edad Media».

También los humanistas, de otra parte, eran en buena medida claros herederos de la Edad Media, una época que, cada vez más, se nos muestra como menos oscura de lo que, con frecuencia, ha llegado a parecer a algunos investigadores; ${ }^{100}$ no se trata de que, por ser eruditos en lo clásico, amén de por razones personales, tuviesen los humanistas ese ansia de elocuencia, ideal persistentemente buscado en sus escritos, sino que, al contrario, eran precisamente y ante todo retóricos profesionales, herederos de los retóricos medievales, ya que en el Renacimiento italiano ${ }^{101}$ fue la retórica tan necesaria, si no más, como lo había sido en la antigua Grecia, Bizancio ${ }^{102}$ o en la Edad Media. ${ }^{103}$ Leonardo Bruni, ${ }^{104}$ por ejemplo, un alumno de Chrysoloras — también lo fueron

100 La importancia de la escolástica medieval no necesita ser subrayada; claro es, como ha precisado J. Le Goff, Los intelectuales en la Edad Media, trad. esp., Barcelona, 1986, p. 95, que se trata fundamentalmente de la escolástica del s. XIII, en todo su vigor, manejada por espíritus agudos: «El escolasticismo de la época del gótico flamígero de fines de la Edad Media podrá con razón suscitar el desprecio de un Erasmo, de un Lutero, de un Rabelais. El escolasticismo barroco despertará la legítima repugnancia de un Malebranche. Pero la inspiración y los hábitos del escolasticismo se incorporaron a los nuevos progresos del pensamiento occidental. El propio Descartes le debe mucho», y Le Goff trae en apoyo de estos juicios la opinión de un gran entendido en la filosofía medieval, Étienne Gilson. A propósito del significado de la obra de este último investigador para la intelección del Medievo véase, por ejemplo, recientemente, J.A. Aertsen, «Tendencies and Perspectives in the Study of Medieval Philosophy», en J. Hamesse (ed.), Bilan et perspectives des études médiévales en Europe. (Actes du Premier Congrès Européen d'Études Médiévales. Spoleto 1993), Lovaina la Nueva, 1995, pp. 109-116.

101 Remitimos aquí únicamente a las atinadas observaciones que sobre algunas de las utilidades de la retórica en época renacentista desgrana M.A. Ochoa Brun, «La diplomacia y la cultùra renacentista», en J.M. Aniel-Quiroga et alii, Diplomacia y Humanismo, Madrid, 1989, p. 33. Nótese también que no están ausentes críticas antirretóricas entre los humanistas; véase, por ejemplo, V. Florescu, La thétorique et la néorhétorique. Genèse, évolution, perspectives, ParísBucarest, 1982, pp. 114-117, a propósito de Ermolao Barbaro, Leonardo da Vinci, Francesco Patrizzi y Campanella.

102 Una exposición general sobre la retórica en el Medievo griego (teoría y práctica) puede verse en Hunger, Die hochsprachliche Literatur der Byzantiner, I, Múnich, 1978, pp. 65-196; son muy útiles también G. Kustas, «Function and Evolution of Byzantine Rhetoric», Viator, 1 (1970), pp. 55-73; G.A. Kennedy, Greek Rhetoric under Christian Emperors, Princeton, N. Jersey, 1983, pp. 291-325, que traza un rápido panorama de la retórica bizantina a partir del s. X; y J. Monfasani, «The Byzantine Rhetorical Tradition and the Renaissance» en J. J. Murphy (ed.), Renaissance Eloquence. Studies in the Theory and Practice of Renaissance Rhetoric, Berkeley-Los Ángeles-Londres, 1983, pp. 174-187.

103 Véase, en general, J. J. Murphy, La retorica nel Medioevo. Una storia delle teorie retoriche da s. Agostino al Rinascimento, trad. it., Nápoles, 1983 (hay trad. esp.)

104 Hay una serie de trabajos de Hans Baron fundamentales para la vida y obra de Bruni, un personaje de extraordinaria importancia en el humanismo republicano; mencionemos simplemente su hermoso libro The Crisis of the Italian Renaissance. Civic Humanism and Republican Liberty in a Age of Classicism and Tyranny, Princeton, N. Jersey, 1966 (es reimpr.), que traza un detallado panorama de la época y analiza cuidadosamente las ideas de Bruni, canciller de Florencia, y de otros coetáneos. No obstante, las críticas hechas a Baron sobre su teoría de que el nacimiento de los valores específicamente renacentistas (en el terreno político) tuvo lugar en el enfrentamiento de los florentinos contra el duque de Milán a principios del s. XV, son muy abundantes. Que el material conceptual político utilizado en la oratoria de esta época no es sino un calco del que nos han transmitido los dictatores medievales - aunque, claro es, las conclusiones son diferentes- puede verse estudiado con detención en Q. Skinner, Los fundamentos del pensamiento político moderno. I. Renacimiento, trad. esp., Méjico, D.F., 1985, pp. 91-106. De otro lado, los aspectos técnicos de la influencia medieval 
Vergerio, Guarino, Rossi, Scarperia y otros-, buscó textos que le pudiesen ser útiles para glorificar el republicanismo de Florencia y no encontró nada mejor que echar mano del Panathenaikos de Elio Aristides para su Laudatio de la ciudad ${ }^{105}$. Pero, además, eran también personas - y en ello seguimos las ideas de Kristeller- ${ }^{106}$ «que creyeron, algo por aquel entonces nuevo y moderno [la cursiva es nuestra], que el mejor modo de lograr la elocuencia estaba en imitar los modelos clásicos; por tanto, se vieron obligados a estudiar los clásicos y a fundar la filología clásica». No se trata tampoco de que el humanismo haya sido, como pretenden algunos, la nueva filosofía del Renacimiento, «surgida en oposición al escolasticismo, la vieja filosofía de la Edad Media». El movimiento humanista, en definitiva, para Kristeller, continuó la tradición gramatical y retórica medieval «representada, por ejemplo, por el ars dictaminis y el ars arengandi, pero dándole una dirección nueva, que buscaba las normas y los estudios clásicos, posiblemente debido a la fuerza de las influencias recibidas de Francia mediado ya el siglo XIII». Sin embargo, este punto de vista no debe dejar de lado, como cautela metodológica, una salvedad sobre la que este mismo investigador insistió años más tarde: «si cierto es que, en muchos de sus aspectos, el Renacimiento puede quedar unido a precedentes medievales [...], —escribe_ ${ }^{107}$ igualmente cierto resulta que esos fenómenos medievales al parecer anunciadores de ciertas evoluciones del Renacimiento no necesariamente ocupan el centro del escenario en su respectivo período o, en especial, durante la fase inmediatamente anterior al Renacimiento». Quiere decir esto, simplemente, que en el siglo XV el humanismo ocupó una posición mucho más central que la que el ars dictaminis llegó a ocupar en el universo intelectual de los siglos XII y XIII, aunque ello nada resta a la muy posible influencia de este segundo, el ars dictaminis, sobre el primero. En resumidas cuentas, para Kristeller, «cuando le buscamos al Renacimiento precedentes medievales, acaso veamos la Edad Media con una perspectiva diferente a la que solemos aplicarle cuando la tomamos en sí y con referencia a las tendencias en ella dominantes. Esa perspectiva diferente - prosigue este investigador- puede ser muy instructiva mientras no pretendamos que es la única legítima». Si hemos recogido con cierta detención estas últimas ideas de Kristeller es porque se corre el riesgo de que, al encontrar precedentes de las «novedades» del Renacimiento, esos mismos precedentes pasen a ser considerados automáticamente «novedades» en su propio ámbito medieval, con el consiguiente peligro de distorsión de la realidad histórica; para Kristeller, finalmente, «no hay duda ninguna de que existió un

(véase, por ejemplo, Murphy, La retorica, pp. 223-304, sobre el ars dictaminis, y 305-403, sobre el ars predicandi) y las diversas teorías sobre aquélla se encuentran señalados, con buena bibliografía, en Gómez Moreno, España, pp. 91, 163 y 167, y, en general, véase Kristeller, «La filosofía y la retórica de la Antiguiedad al Renacimiento», parte quinta del volumen ya citado El pensamiento renacentista, pp. 283-344. Se trata de una cuestión de mucho interés -en ambas dimensiones (la política y la literaria) - que pone de nuevo sobre la mesa las relaciones con el Medievo y lo que esto significa para un estudio del Renacimiento.

105 Baron, «Imitation, Rhetoric, and Quattrocento Thought in Bruni's Laudatio», en From Petrarch to Leonardo Bruni, Chicago, 1968, pp. 151-153 y 155-171, creyó que Bruni fue precisamente el primer humanista italiano que no imitó meramente los ideales políticos griegos y romanos sino que los aplicó creativamente a los sucesos de su propia época; véase lo ya dicho más arriba acerca de las críticas a la concepción de Baron, así como P. Burke, El Renacimiento italiano. Cultura y sociedad en Italia, trad. esp., Madrid, 1993, pp. 224-225.

106 «El humanismo y el escolasticismo en el Renacimiento italiano», artículo de 1944, recogido en El pensamiento renacentista, pp. 122-125.

107 «a filosofía renacentista y la tradición medieval», p. 154. 
Renacimiento italiano; es decir, un Renacimiento cultural de Italia no tanto en contraste con la Edad Media en general o con la Edad Media francesa sino, muy definitivamente, en contraste con la Edad Media italiana». 108

Aparte de la interesante precisión cronológica antedicha, consistente en la casi simultaneidad en lo que respecta al desarrollo del aristotelismo y el humanismo en Italia, debemos a Kristeller otras muchas conclusiones de interés. En general, la crítica que los renacentistas hicieron contra lo medieval no ha pasado nunca, según la opinión de este investigador, de un nivel poco profundo; los humanistas se oponían al Medievo en aspectos literarios, intelectuales, filosóficos, científicos y éticos, pero no siempre acertaron en su argumentación. Es de señalar que Petrarca alaba a Platón frente a Aristóteles, aunque es muy cierto que lo que conocía del filósofo de la Academia - y de ello volveremos a hablar- era ciertamente bastante poco. ${ }^{109}$ En otro orden de cosas, en el caso concreto de la ciencia esta vez, resulta paradigmático el tipo de crítica superficial que los humanistas alumbraron contra los textos medievales: «sus cargos principales» —afirma Kristeller - consistían meramente «en atacar el mal estilo latino de los autores [...], la ignorancia de éstos en cuestiones de historia y literatura antigua y su interés en cuestiones supuestamente inútiles». ${ }^{110}$ En resumidas cuentas, todo lleva a pensar que el sentido de las críticas a un movimiento prácticamente coetáneo, como ya se ha visto, el aristotelismo, debería de ser considerado más bien, a la vista de lo mucho que de novedoso para Italia había en él, como un simple ataque propio de la rivalidad entre dos departamentos de una misma Universidad, en vez de como un choque de ideas filosóficas opuestas; en su Dialogus de tribus vatibus florentinis el propio Leonardo Bruni (1370-1444) llega a insinuar que no habla del todo en serio al hacer sus críticas. ${ }^{111} \mathrm{Y}$, por supuesto, ha de quedar claro que no siempre aristotelismo va unido a pensamiento medieval o escolasticismo ni tampoco a tomismo, ${ }^{112}$ en lo que a críticas toca. Desde Petrarca (1304-1374) hasta Giordano Bruno (1548-1600) y Galileo (1564-1642), por lo tanto, la rebelión antiaristotélica o, por lo menos, la rebelión contra sus intérpretes medievales, ha sido moneda corriente entre los renacentistas, pero ni ha sido un movimiento unificado ni tampoco ha resultado del todo efectivo. Dejando a un lado que el aristotelismo atacado por Petrarca no llevaba ni siquiera cien años enseñándose en Italia, es interesante que señalemos además que lo que otros humanistas del s. XV criticaron decididamente, Ermolao Barbaro (1453-1493) y Leonardo Bruni, por ejemplo, fue el escolasticismo de viejo cuño, pero no al «maestro de los que saben», al propio Aristóteles; además, su ataque se hizo con frecuencia en una multiplicidad de aspectos, generales o particulares, concebidos no por todos los críticos de igual mane-

108 «El humanismo y el escolasticismo», p. 118.

109 «El platonismo bizantino», p. 210.

110 «El humanismo y el escolasticismo», p. 125.

111 Ibidem, p. 143.

112 Fundamental para el análisis de las relaciones entre el tomismo y el pensamiento renacentista es el estudio de Kristeller, «Thomism and the Italian Thought of the Renaissance», en Medieval Aspects of Renaissance Learning. Three Essays by P.O.K. edited and translated by E.P. Mahoney, Nueva York, 1992, pp. $29-91$ (es reimpr.). Desde los manuscritos de obras de Sto. Tomás copiados por humanistas hasta los discursos pronunciados en los aniversarios de su muerte por ilustres eruditos como Valla y Barbaro, pasando por los tratados críticos y las polémicas con los platónicos de la época, todo lo que tiene que ver con el binomio «tomismo/pensamiento renacentista» es analizado en un artículo de soberbia erudición. 
ra. El citado Barbaro, por ejemplo, autor de las famosas Castigationes Plinianae, sostuvo - lo que podría elevarse a la categoría de paradigma más general- que las equivocaciones de Plinio eran debidas en su mayor parte a los fallos que los copistas tuvieron al transmitirnos su texto; por su parte, Niccolò Leoniceno, profesor de medicina de Ferrara, se opuso a esta crítica sosteniendo que, en realidad, lo que ocurría es que Plinio no sabía demasiado y, por ello, hasta llegó a poner en peligro la salud de los desprevenidos lectores que siguieron sus consejos. La postura de un tercer humanista, Pandolfo Collenuccio, resulta de una claridad meridiana y nos acerca de un modo insuperable al terreno en el que no pocas de estas discusiones debían de presentarse normalmente: las controversias de este tipo, sentenció Collenuccio, no se aclararían jamás con la consulta a las autoridades ni a los diccionarios sino, más bien, yendo a los campos y bosques, mediante la observación y experimentación directa en suma. ${ }^{113} \mathrm{El}$ ataque a lo que les parecía ser un saber libresco y antiguo, alejado de la realidad, es bien claro en estos humanistas, y sus ecos tendremos ocasión de encontrarlos en los autores españoles que analizaremos en otro lugar. Con todo, antes de seguir adelante, tal vez no sea ocioso subrayar algo que para muchos es también obvio: a saber, que no siempre el saber medieval merecía esas críticas. Efectivamente, los problemas y discusiones del Medievo pueden parecernos ridículos hoy, pero lo son en tanto que muchas veces no sabemos de qué se está discutiendo exactamente. Cierto es que se discute vivamente sobre los ángeles que pueden colocarse en la punta de una aguja pero, como ha llamado la atención A. Koyré, ${ }^{114}$ «lo que está en juego es saber si el espíritu, si un ser o un acto espiritual - un juicio por ejemplo- ocupa o no un lugar en el espacio... Y esto ya no es en absoluto ridículo». Por otro lado - hay que reconocerlo—, sí que hubo un escolasticismo de meros exégetas con una dogmática fosilizada, de forma que la reacción humanista es en parte perfectamente explicable.

Por lo que toca ahora a aspectos más concretos, examinemos algunos ejemplos que tienen que ver con la exigencia humanista de un tipo de saber aplicado a la vida diaria, real, un saber útil, en suma, que se apartara de lo que para muchos era el saber medieval. Digamos a este respecto, lo primero de todo, que, más allá de la corrección de los textos, de la evitación de las erratas, al otro lado de los pormenores de sintaxis, había en los humanistas una actitud que, en palabras de Francisco Rico, ${ }^{115}$ «invitaba a franquear las fronteras de la lengua y la literatura e invadir territorios aun más vastos [...] Para empezar, los pioneros [...] habían adivinado en la Antigüedad un modelo global, válido en los más diversos ámbitos, y globalmente aspiraban a resucitarlo». De otra parte, todos sus saberes «partían de un hastío de las quidditates y las quintaesencias medievales y postulaban el

113 «Lo que me interesa subrayar aquí -ha escrito Rico, El sueño, pp. 154-155, comentando estas opiniones encontradas- «es que las dos posturas heredan el sueño del humanismo y ninguna lo realiza. La confianza de Barbaro al poner al autor antiguo por encima del error respondía en definitiva al talante originario del movimiento, explicable en un estadio en que el mero hecho de leer correctamente a los clásicos [...] significaba, en efecto, añadir datos preciosos a la comprensión y conquista de la realidad». Había, pues, que depurar el texto de Plinio como primera providencia; sin embargo, la «ruptura con Plinio» propugnada por Leoniceno era igualmente necesaria, ya que «el filón greco-latino tenía unos límites», y saber esto, darse cuenta de estas limitaciones, suponía una actitud intelectual valiosa. Para la De Plinii et plurimum aliorum medicorum in medicina erroribus [...] Epistola ad Hermolaum Barbarum... escrita por Leoniceno, véase Bianchi, «Aristotele», p. 516.

114 «Aristotelismo y platonismo», p. 17.

115 El sueño, pp. 42-43. 
ideal de un saber que volviera a la realidad» (la cursiva es nuestra). En este mismo sentido precisamente ha insistido Hans Baron ${ }^{116}$ al comentar un pasaje del De legibus, donde Cicerón afirma que su tarea consiste en «sacar el saber de las profundidades melancólicas del estudio [...]; no sólo exponerlo a la luz del sol sino ponerlo en línea de batalla y en el centro de los conflictos». Esta idea, que ya está en el De oratore, propugna que la cultura se acerque a la vida diaria y se unan teoría y práctica, al interesarse el sabio tanto por los asuntos privados como por los públicos, tal como había hecho la figura ejemplar de Catón el Censor. Y así, Lorenzo Valla llegará a sentir un cierto desprecio por Aristóteles, dado que el de Estagira no había juzgado oportuno dedicarse a las cosas de la vida pública: «porque no se dio - afirma— a los quehaceres que más que cualesquiera otros revelan a los grandes hombres: intervenir en los asuntos públicos, sea ante el pueblo o en el senado, administrar provincias, conducir un ejército, defender causas, practicar la medicina, hacer justicia, dar dictámenes, escribir historias, componer poesía». ${ }^{117}$ Los escolásticos, de otra parte, fueron batidos progresivamente desde Valla a Ramus también en el terreno de la lógica, reformada con la retórica, y no tardó en presentarse una batalla más dura que puso en peligro al aristotelismo: se trataría esta vez de las críticas a la filosofía natural, hechas no desde el punto de vista de lo que hoy día podríamos llamar «ciencia» 0 «método científico» moderno sino de las objeciones normales salidas de dentro del propio sistema; ${ }^{118}$ estas críticas alcanzaron luego un nivel mucho más profundo en el s. XVII con autores como Galileo, matemático y astrónomo profesional, quien, para Kristeller, en su calidad de filósofo natural, dio en postular «una física nueva, basada en los experimentos y en los cálculos, una física de las cantidades que, como fundamento, no tenía la lógica formal sino las matemáticas, y que terminaría por relacionarse íntimamente con la astronomía». La revolución antiaristotélica, pues, a partir del Renacimiento nos llevará en derechura a los albores de la época moderna, pero hay que precisar que adquirirá su vigor en fecha posterior; en muchos sentidos, por lo tanto, concluye Kristeller de acuerdo con otros estudiosos, «el Renacimiento sigue siendo una época aristotélica, que en parte mantuvo las tendencias del aristotelismo medieval y en parte les dio una dirección nueva debido a la influencia del humanismò clásico y a otras ideas». ${ }^{119}$ De nuevo tenemos aquí esa solución de compromiso entre lo antiguo y lo nuevo, adornada con una crítica cuyo exacto sentido no es siempre fácil de adivinar.

En definitiva, tal como la interpretación de Kristeller, jugosa, matizada e informada, nos ha mostrado, la idea de que el Renacimiento es una época de ebullición intelectual, de descubrimiento de nuevos valores, pero separada a cal y canto de la Edad Media, sin precedente alguno, nacida en el vacío, no puede en modo alguno sostenerse; antes bien, hay que reconocer, con la anuencia de otros muchos estudiosos modernos, que la oposición del Renacimiento a la Edad Media no es ni

116 «Remembranza del espíritu cívico romano de Cicerón a lo largo de los siglos medievales y en el Renacimiento florentino», trabajo publicado en 1938, recogido en En busca del Humanismo cívico, pp. 91-92.

117 Repastinatio dialectice et philosophie, I, 5; véase Rico, El sueño, p. 88, n. 84.

118 Para todo esto véase «La tradición aristotélica», pp. 68-72.

119 «Para resumir el tema asaz complejo de Aristóteles en el Renacimiento, quizá lo mejor sea afirmar que continuaron las tradiciones aristotélicas de la tardía Edad Media (especialmente en los campos de la física y la lógica); que al lado de ellas surgió un nuevo aristotelismo humanístico, basado en las nuevas traducciones y con su centro en la ética, lá retórica y la poética; y, finalmente, que hubo un creciente movimiento antiaristotélico, compuesto de varias oleadas muy diferentes, el que consiguió cierto éxito en la lógica y: poco a poco, preparó el terreno para que en el siglo XVII se acabara con la física de Aristóteles». (Kristeller, «La filosofía renacentista y la tradición medieval», p. 180). 
mucho menos tan grande como se suele imaginar. Hoy día, ha escrito por ejemplo P. Burke, ${ }^{120}$ «los historiadores ponen en tela de juicio, por exagerados, los espectaculares contrastes que el autor [Burckhardt] ${ }^{121}$ señala entre el Renacimiento y la Edad Media, y entre Italia y el resto de Europa, ya que tales contrastes se producen por no haber tenido en cuenta las diversas innovaciones que se realizaron durante la Edad Media, la pervivencia de actitudes tradicionales en el siglo XVI e incluso más tarde, ni tampoco el interés de los italianos por la pintura y por la música de los Países Bajos». En primer lugar, prosigue Burke, ${ }^{122}$ «existen razones para afirmar que los llamados "hombres del Renacimiento" eran en realidad bastante medievales. Su comportamiento, postulados e ideales eran más tradicionales de lo que tendemos a creer y de lo que ellos mismos pensaban». Se ha sugerido, continúa este investigador, «que incluso Petrarca, "uno de los primeros hombres realmente modernos" según Burckhardt [...], por su creatividad tanto poética como intelectual, tenía muchos puntos en común - y a esto ya se ha hecho referencia en estas páginas - con la época que él mismo describió como "oscura". Dos de los más famosos libros escritos en el siglo XVI, El cortesano y El príncipe, están más próximos a la Edad Media de lo que parece. El cortesano de Castiglione está inspirado en las tradiciones medievales de la cortesanía y el amor cortés, así como en textos clásicos como el Banquete de Platón y el De los deberes de Cicerón. Incluso El príncipe de Maquiavelo, que algunas veces modifica deliberadamente el saber convencional, pertenece hasta cierto punto a un género medieval, el de los llamados "espejos" o libros de aviso para gobernantes». En definitiva, «esta simple oposición binaria entre la Edad Media y el Renacimiento, tan útil a efectos explicativos, es en muchos aspectos errónea». ${ }^{123}$ Por otro lado, ya en $1918 \mathrm{~K}$. Burdach ${ }^{124}$ se opuso a la interpretación pagana del Renacimiento ${ }^{125}$ que básicamente mantenía Burckhardt e insistió — de una

120 El Renacimiento, p. 8.

121 Se refiere a la famosá obra La cultura del Renacimiento en Italia, 2 vols., trad. esp., Barcelona, 1985, 2. ${ }^{\text {a ed. }}$

122 El Renacimiento, p. 12.

123 Ibídem, p. 97.

124 Riforma, Rinascimento, Umanesimo. Due dissertazioni sui fondamenti della cultura e dell'arte della parola moderne, Florencia, 1986 (se trata de una reed. de la trad. ital. de 1935 con una excelente introducción a cargo de C. Vasoli).

125 No podemos entrar aquí en el complejo tema de la religión renacentista; sobre aspectos diversos de esta cuestión puede consultarse D. Cantimori, Humanismo y religiones en el Renacimiento, trad. esp., Barcelona, 1984, así como diversos trabajos de Monfasani («Platonic Paganism in the Fifteenth Century», por ejemplo, recogido en Byzantine Scholars in Renaissance Italy) y de J. d'Amico, todos ellos con ideas de interés y una buena orientación bibliográfica; tan sólo el nombre de Erasmo evoca una bibliografía inmanejable y una inabarcable serie de influencias en España y otros países. Reflexiones también interesantes encontrará el lector en Kristeller, «Paganismo y cristianismo», trabajo de 1955, recogido en El pensamiento renacentista, pp. 93-97; así, en p. 97 escribe: «estoy convencido: de que el humanismo no fue, en su centro mismo, ni religioso ni antirreligioso, sino una orientación literaria e intelectual que podía ser, y en muchos casos era, llevada a cabo sin ninguna referencia explícita a temas religiosos por parte de individuos que, a la vez, eran miembros fervientes o nominales de una de las iglesias cristianas. Por otra parte, había muchos eruditos y pensadores de preparación humanística que tenían un interés genuino en los problemas religiosos y teológicos, y es mi opinión que la manera en la cual aplicaron su preparación humanista al material original y a los temas de la teología cristiana fue uno de los factores causantes de los cambios sufridos por el cristianismo durante ese período. Los elementos más importantes en el enfoque humanista de la religión y la teología» —en definitiva — fueron, según Kristeller, «el ataque al método escolástico y la insistencia en la vuelta a los clásicos, que en este caso significaba los clásicos griegos cristianos o, en otras palabras, la Biblia y los Padres de la Iglesia». Por lo que toca a la influencia de los Padres en el Renacimiento - ya señalada en la conocida obrita de W. Jaeger, Cristianismo primitivo y paideia griega, trad. esp., Méjico, D.F., 1965, p. 139 (la influencia de los Padres «sobre el pensamiento renacentista, tanto en Italia como en el resto de Europa», escribió este autor aquí, en 1961, «es todavía un problema no resuelto»)- véanse ahora los estudios de L. Stinger, en especial, su Humanism and the Church Fathers. Ambrogio Traversari (1386-1493) and Christian Antiquity in the Italian Renaissance, Albany, Nueva York, 1977. 
manera todavía más tajante que éste— en que la restauración de la Antigüedad no fue el elemento decisivo; de otro lado, ver novedades absolutas en el Renacimiento, unirlo a movimientos posteriores como la Ilustración, el liberalismo, etc., es también un gran error, ya que aquél, es igualmente opinión de Burdach, aunque la cursiva es nuestra, hunde directamente sus raíces en la Edad Media. Para este investigador, en suma, «il movimento umanistico, il Rinascimento non hanno assolutamente nulla in comune con la libertà politica intesa in senso moderno, nel senso del liberalismo europeo derivato dalla Rivoluzione francese». ${ }^{126}$ Finalmente, pocos textos hay más claros que el de Jean Delumeau, ${ }^{127}$ si lo que interesa es retratar esta pervivencia de lo clásico desde la Edad Media y, a la vez, algunas de sus mutaciones renacentistas posteriores, en sólo un par de párrafos: «Los hombres del Renacimiento» - ha escrito este investigador francés— «simplificaron la historia, ya que la Edad Media nunca perdió por completo el contacto con la Antigüedad. Zafio de espíritu y limitado en influencia, el "Renacimiento carolingio" tuvo, no obstante, el mérito de conservar y recopiar numerosos manuscritos de autores antiguos: preciosa reserva para la posteridad. Los siglos XI y XII fueron testigos a su vez - continúa este investigador - de un nuevo auge de los estudios clásicos, y también respecto a esa época se ha hablado, exageradamente sin duda, de "Renacimiento". En Francia, en las escuelas que florecieron cerca de los cabildos catedralicios, se comentaba a Virgilio, Ovidio, Juvenal, Estacio, Horacio, Lucano, Salustio, etc. En los debates morales no se vacilaba en citar la obra De amicitia de Cicerón y las epístolas de Séneca. Las monjas leían devotamente el Arte de amar de Ovidio, ${ }^{128}$ y se les daban extractos comentados de las Metamorfosis. ¿Es acaso preciso para demostrar la supervivencia, durante los largos siglos de la Edad Media, de una Antigüedad, si bien a menudo deformada, recordar el prolongado éxito de los Roman de Tebas, de Troya o de Eneas? Hecho menos conocido, pero tal vez más significativo» es para Delumeau que Petrarca, a la hora de componer el tercer canto de su epopeya latina Africa, que exaltaba la figura de Escipión, acudió a un cierto Liber ymaginum deorum medieval, especie de diccionario mitológico compuesto a principios del siglo XIIII. Así pues — concluye este mismo investigador-, «el humanismo, en su nacimiento, no vacilaba en recurrir a las compilaciones medievales, referentes a la Antigüedad». ${ }^{29}$

126 Véase Ciliberto, o.c., p. 21.

127 La civilización, p. 102.

128 Ibídem, p. 111: «Verdad es que la Antigüedad nunca se vio totalmente olvidada, pero sí transformada. Las monjas leían a Ovidio, pero era un Ovidio moralizado. En los Poemas de Troya o de Eneas, en ciertas "traducciones" de Tito Livio o de Valerio Máximo, en las miniaturas, los héroes antiguos se convertían en caballeros, las diosas en grandes damas ataviadas a la moda de Carlos VI o Carlos VII [...] Los humanistas, por el contrario, se esforzaron - si bien es verdad que sin conseguirlo siempre- en recuperar una Antigüedad más auténtica». No quiere decir esto tampoco, claro está, que la Edad Media leyese a los clásicos sólo desde un punto de vista moral mientras que el Renacimiento lo hizo en cambio sólo desde uno artístico; véanse a este propósito las reflexiones de Gómez Moreno, España, pp. 87-88 y, en especial, 160.

129 Y, si mencionamos las artes, el Medievo no dejó de revivir a su manera el mundo antiguo; traemos aquí de nuevo las palabras de Delumeau, La civilización, pp. 102-103: «los escultores romanos «se inspiraron en estatuas, bajorrelieves, estelas y sarcófagos abandonados por la Antigüedad en el transcurso de su reflujo. El antiguo tímpano de Saint-Ursin, de Bourges, que representa una magnífica escena de caza para la que un sarcófago sirvió de modelo, el Hércules de la catedral de Langres, los capiteles que evocan el rapto de Ganimedes en Vezelay y una pelea de gallos en Saulieu, son otros tantos lazos renovados con la civilización romana. El arte gótico mismo bebió en las fuentes de la Antigüedad. En el campanil de Giotto, en Florencia, bajo el alto patronazgo de los Profetas y de las Sibilas, los dioses planetarios se alinean al lado de las Virtudes, las Ciencias y los Sacramentos. En la catedral de Reims, ciertas estatuas, en particular el célebre grupo de la Visitación, realizado hacia 1230, tienen un aire tan clásico que su anónimo escultor ha sido llamado el "maestro de las figuras antiguas". Probablemente éste jamás habría visitado Atenas, pese a la hipótesis de E. Mâle, sino que debió de buscar inspiración en las numerosas ruinas galo-romanas de la región remense». 


\section{NOVEDADES E INNOVADORES: ALGUNOS EJEMPLOS}

Pero, claro está, toda la continuidad y desarrollo del pensamiento que pueda descubrirse entre Medievo y Renacimiento, que no es poca según hemos visto en el representativo. pero a la vez obligatoriamente limitado mosaico de opiniones del apartado anterior, en poco también altera la impresión de cambio de actitud - en concreto de rebelión contra las auctoritates- que de una manera francamente generalizada ya nos es dado ver en tiempos de Leonardo de Vinci (14521519), por ejemplo, y en nuestro siglo XVI, teniendo aquélla como referencia negativa no pocas veces el texto de Aristóteles. A este propósito, tres son las ideas que, no por conocidas, debemos dejar de traer a colación. En primer lugar, la protesta, la rebelión contra una Edad Media que, a juicio de no pocos humanistas, en buena parte se reputaba como fosilización de un pensamiento antaño esplendoroso y productivo (y con brillos tardíos considerables en algunas parcelas del conocimiento), no parece ser del todo significativa ni por sus motivos reales, ni por sus argumentos, ni tampoco por sus consecuencias, como Kristeller ha mostrado. Y lo que todavía parece más seguro es que los orígenes de ese antiaristotelismo pueden verse ya, como tomaremos en consideración más adelante, en la propia Edad Media, lo que supone poner en tela de juicio que haya sido justamente el Renacimiento el que, entre sus «novedades», deba incluir radicalmente la rebelión contra las auctoritates. En segundo lugar, no todos los autores se alinean con la misma intensidad y al mismo tiempo en sus críticas; un paseo por las páginas de la Historia de la filosofía española de Alain Guy ya citada, por no acudir a otra de más pormenor, nos muestra una multiplicidad de conductas particulares, de posturas teóricas y de escuelas que producen no poco desasosiego en el lector, deseoso siempre de encontrar una homogeneidad a ultranza, expuesta con pedagógica uniformidad. Las oscilaciones entre aristotélicos de corazón, tibios, críticos y, de otro lado, los platónicos, sorprenden por su variedad; pero, además, ¿qué orientación tenían los textos que leyeron? En este último punto, el paralelo con lo que ocurre en Europa es también flagrante. Maquiavelo, al parecer, leyó a Aristóteles, pero ¿qué Aristóteles?, ¿el de los escolásticos o el de los averroistas? ¿Lo leyó como discípulo o como crítico? ¿Quiso continuar su pensamiento, anotarlo u oponerse a él? ${ }^{130}$ Y lo que decimos sobre Maquiavelo podría aplicarse, en este mismo contexto de ambigüedad, a otras parcelas del pensamiento. Incapaz de conservar el aristotelismo, ya fuese el auténtico o el medieval, incapaz al mismo tiempo de desembarazarse de él, la medicina europea del s. XVI, ha escrito J. Roger, ${ }^{131}$ oscilará entre la condena más patente y la glorificación (aunque con matices) del estagirita. Admitidos estos dos argumentos, las especiales características renacentistas y la antigüedad remota de la rebelión contra las auctoritates -en nuestro caso, como es de esperar, Aristóteles o sus intérpretes, fundamentalmente- $y$, por otro lado, la pluralidad de elecciones y grados en ellas que los medievales y sobre todo los renacentistas tuvieron a su alcance, asuntos éstos sobre los que se hablará con mayor detención, hora es ya de tomar en conside-

130 Véase B. Guillemain, «Maquiavel, lecteur d' Aristote», en la obra colectiva Platon et Aristote à la Renaissance (XVIe Colloque international de Tours), París, 1976, p. 163.

131 «Platon et Aristote dans le mouvement scientifique de la Renaissance. La situation d'Aristote chez les anatomistes padouans», en Platon et Aristote à la Renaissance, p. 217. 
ración algún caso típico, modélico se podría decir, que nos dé la pauta de lo que vamos a encontrar en nuestro s. XVI, en el análisis más pormenorizado que llevaremos a cabo en la segunda parte de este trabajo.

Un estudioso como Juan Luis Vives (1492-1540), por ejemplo — sobre el que sigue siendo de interés el estudio de Adolfo Bonilla y San Martín-, ${ }^{132}$ puede ser muy bien nuestro punto de partida. Vives, como otros muchos, hará «arrancar de Aristóteles y su escuela el verdadero saber de las cosas naturales y de los hombres» según ha escrito Maravall, ${ }^{133}$ al tiempo que, en su opinión, de los filósofos anteriores, tan sólo Platón merece para él ser destacado, «aunque su obra no tiene demasiado valor educativo». ${ }^{134}$ Escribió Vives, con todo, una «censura» de las obras aristotélicas (Censura de Aristotelis operibus, Estrasburgo 1538) y se extiende aquí y allá en su vasta obra sobre la impropiedad de muchas cosas que suelen presentarse como ejemplos ofrecidos por los antiguos griegos y latinos. ${ }^{135}$ En el De disciplinis, obra fundamental, se critica en concreto al Estagirita, pero también a Platón, Cicerón, Plinio, Quintiliano, Boecio y, por supuesto, el ciceronianismo de Valla. «Ciertamente - viene a escribir Maravall parafraseando al valenciano-, ${ }^{136}$ los antiguos inventaron las artes con gran esfuerzo y por ello merecen gratitud; pero ni los antiguos dejaron de cometer graves yerros, de manera que la corrupción que en las artes se encuentra no puede decirse que sea obra tan sólo de los modernos, sino que se inicia desde el origen de aquéllas, ni nacieron éstas tan perfectas que no hayan necesitado muchas correcciones posteriores, de modo que no es justo creer que no haya habido que añadir muchas conquistas y perfecciones posteriores». Aristóteles, para Vives, viene a ser realmente un autor oscuro, ${ }^{137}$ y esto «no sólo por ulterior corrupción de los

132 Luis Vives y la filosofía del Renacimiento, Madrid, 1903 (hay reimpr.).

133 Antiguos, p. 289.

134 En general, en torno a las opiniones de Vives sobre Platón y Aristóteles, véase J.-C. Margolin, «Vivès, lecteur et critique de Platon et d'Aristote», en Bolgar (ed.), Classical Influences, pp. 245-258; para lo que se refiere a Aristóteles en la influyente obra De disciplinis, puede verse V. del Nero, Linguaggio e filosofia in Vives. L'organizzazione del sapere nel «De disciplinis» (1531), Bolonia, 1991, pp. 99 y ss.

135 Son de mucho interés sus juicios críticos acerca de las realizaciones de la Antigüedad, que, en general, debe ser considerada como la juventud de la Humanidad; «el hecho de que esta actitud no se acomode bien al cuadro del Renacimiento comúnmente aceptado, que lo ve como un período fascinado por las soberbias realizaciones de la antigüedad clásica, prueba tan sólo la originalidad del pensamiento de Vives y la complejidad de su época» (Noreña, o.c., p. 185). De otra parte, Noreña, ibidem, p. 195, subraya que «el interés de Vives por Grecia fue siempre derivado e incompleto».

136 Antiguos, p. 303.

137 La obra clave del s. XVI sobre la oscuridad del filósofo de Estagira - obra «destinata a segnare uno dei momenti più alti del dibattito cinquecentesco sui metodi di interpretazione del pensiero peripatetico», en palabras de L. Bianchi, "'Aristotele fu un uomo e potè errare": sulle origini medievali della critica al "principio di autorità"» en Bianchi (ed.), Filosofia e teologia, p. 519- es sin duda la de Pedro Juan Núñez, Oratio de causis obscuritatis Aristotelis, Valencia, 1554, cuyas consideraciones van ciertamente más allá de las consecuencias de los meandros de la transmisión textual y paran mientes en una serie de causas intrínsecas; cita, entre otras, Abellán, Historia crítica, p. 185, «la variedad de voces para expresar una misma idea, el empleo de voces ambiguas, el tecnicismo con que se usan vocablos de la lengua diaria, el peculiar enfoque aristotélico de las cuestiones, el gran número de argumentos, la sobra de exposiciones redundantes y superfluas y la falta de otras necesarias, las dificultades u oscuridad del mismo objeto de estudio, la atribución a Aristőteles de opiniones que no son suyas y las equivocaciones en que a veces él también incurre [...] Aunque [...] Núnez sigue fielmente a Aristóteles, en él no dejan de observarse algunos rasgos de originalidad que Marcial Solana reduce a tres: 1) el anhelo de armonizar y conciliar las doctrinas platónica y aristotélica; 2) el relieve que suele dar en sus exposiciones a la historia de la filosofía; y 3 ) el espíritu crítico que anima todas sus obras [...]». 
textos en manos de copistas y traductores, sino por defectos e insuficiencias de su propio estilo»; 138 y en su admisión de los errores del Estagirita, de otra parte, no hace Vives, como ya se ha anticipado varias veces y se verá más detenidamente de inmediato, sino testimoniar un aspecto concreto de todo un movimiento europeo contra el principio de autoridad encarnado en los «antiguos», tal como con detención ha estudiado L. Bianchi. El error de la escuela aristotélica, vendrá a decir Rodolfo Agrícola, ha consistido en cristalizar como leyes de validez absoluta los resultados particulares a que había llegado Aristóteles, «hombre por cierto, de ingenio superior, pero sólo hombre, a quien [como tal] podían escapársele muchas cosas, y que así como no fue el primero en investigar, dejó también muchas cosas para que las descubrieran sus sucesores». ${ }^{139}$ Para Vives también, como ya se ha anticipado al tratar de la querelle acerca de los antiguos y los modernos, son verdaderamente muchos los modernos que, en no pocos aspectos, deben ser colocados delante de los pasados griegos y latinos. En el De disciplinis escribirá: «¿quién todavía edifica según las normas de Vitrubio? ¿Quién acomoda su régimen dietético a las prescripciones de Galeno? ¿Quién cultiva el campo al estilo de Varrón o Columela? Muchas cosas enseñó aquel siglo que ahora la experiencia nos demuestra contrarias en el cielo, en la tierra, en los elementos, como lo de la habitabilidad de la zona tórrida, lo de las fuentes del Nilo, lo de los antípodas, y esto en las plantas, en los animales, en las mieses; de los albaricoques nacidos en Roma dice Plinio que eran venenosos y ahora son una pura delicia: ¿Dónde están aquellas ovejas andaluzas que -dice Marcial-iban teñidas de su color nativo? Esto mismo les sucede a aquellos que en estos tiempos nuestros andan a caza de antigüedades: ignoran en qué siglo y entre qué hombres viven. Tanta es su familiaridad con lo que ya pasó para no volver, que son peregrinos en su patria y en medio de los suyos. Desconocen y odian la modalidad y la erudición de su tiempo [...]». ${ }^{140} \mathrm{Si}$, en alguna ocasión, la erudición de Vives ha podido dar la impresión de una identificación con la Edad Media, a la vista está que nada hay de eso y que, una vez más, encontramos aquí la presencia de ese eclecticismo de compromiso, esa ambigüedad de la que nos ha hablado Garrote Pérez, y Margolin ${ }^{141}$ comparte plenamente, que lleva a elegir lo antiguo y lo moderno combinando al tiempo a Platón con Aristóteles y saltando de

138 Para las matizaciones que es necesario introducir en el texto de Vives y la ambigüedad de éste véase Margolin, o.c., pp. 250-251.

139 Véase E. Garin, «Discusiones sobre la retórica», trabajo incluido en Medioevo y Renacimiento. Estudios e investigaciones, trad. esp., Madrid, 1981, p. 99, remitiendo a la obra de R. Agricola, De inventione dialectica libri omnes integri et recogniti..., Venecia, 1558, II, 15. No nos resignamos a dejar de llamar la atención del lector sobre los ecos que pueden detectarse en la frase de Agricola, por cierto, está también en el prólogo del De disciplinis de Vives (patet omnibus veritas; nondum est occupata. Multum ex illa, etiam futuris relictum est). Se trata de un ejemplo más del conocido tópico veritas temporis filia, sobre el que hay una nutrida bibliografía; véanse, por ejemplo, algunas indicaciones en Bravo García, «In circuitu impii ambulant. El tiempo en la historia, la religión y la herejía», en F.J. Lomas y F. Devís (eds.), De Constantino a Carlomagno. Disidentes, heterodoxos, marginados, Cádiz, 1992, p. 26, donde se llama la atención sobre la interpretación, bastante diferente, de Agnes Heller.

140 Citamos por la traducción de L. Riber (Madrid, 1948, 2 vols.), de la que hay reimpr. reciente.

141 Margolin, o.c., p. 257: «ll est difficile de dire, en définitive ce que Vivès admire chez Aristote, et ce qu'il lui reproche. Encore plus difficile d'établir un classement ne varietur entre Platon et Aristote». Resulta de mucho interés el análisis sumario (con indicación de las pp. del De disciplinis) que Margolin lleva a cabo de los numerosos juicios contradictorios sobre el Estagirita que Vives nos ha dejado. Para Noreña, o.c., p. 197, de otra parte, con respecto a Platón «la actitud de Vives fue hasta cierto punto vaga y fluctuante» y, en lo que a Aristóteles toca, «es, asimismo, compleja» (ibidem, p. 199). 
la crítica al elogio. ${ }^{142}$ De todas formas, «al ponerse a contemplar la Historia,» —afirma Maravall-, ${ }^{143}$ "Vives tiene conciencia de asistir a la aurora de la modernidad. Y el estudio de los clásicos tiene para él el valor de un instrumento, particularmente eficaz, eso sí, para potenciar las posibilidades, cada vez más ricas, con el curso del tiempo, que tiene ante sí el hombre moderno. De esta manera, el "Renacimiento de la Antigüedad" que el siglo XV propugnara se convierte en el siglo XVI en el "Renacimiento de los modernos". Tal es la función del mito clásico en la época». Tras Juan Luis Vives, y sin que esto signifique que todos los cambios de apreciación de la obra aristotélica que podemos detectar sean repentinos o compartidos por los escritores renacentistas con la misma intensidad, como ya se ha dicho, las influencias de Pierre de la Ramée (el Ramus al que ya hemos aludido) harán que, tanto en Francia como en España, el aristotelismo de corte medieval desaparezca, aunque no sin las importantes excepciones a que nos hemos referido (el auge de una neoescolástica reformista es la fundamental). El griego y el latín, la cultura antigua, siguen considerándose, sin duda, como un punto de partida en estos tiempos, pero tanto en retórica como en otros campos se nota ya abiertamente una marcada apertura de ideas y actitudes que conduce directamente hacia lo «moderno», hacia la lengua y los poetas vernáculos aún más libremente que antes, ${ }^{144}$ hacia la experiencia de la contemporaneidad - subrayémoslo- en artesanos y científicos. Cada vez más, el sentido que se ve detrás de la palabra imitatio (de los antiguos, por supuesto) se va haciendo más libre y, por poner un ejemplo en el terreno de la literatura, «si empezó siendo en los prerrenacentistas del siglo XV imitación de modelos latinos, más o menos a través de los italianos, si aun en las primeras décadas y hasta gran parte del siglo XVI significa seguir el ejemplo de los antiguos griegos y romanos directamente, en cambio, poco a poco, - así se expresa de nuevo Maravall- ${ }^{145}$ y sin que esta actitud imitativa se borre, tal doctrina viene a significar, mediado el XVI, otra cosa nueva: imitar a la naturaleza y, como ésta lo que hace es crear, el poeta y el artista deberán imitarla». Ahora bien, claro es, eso no se hizo simplemente - puntualicémoslo de nuevo y con renovado énfasis-contra los antiguos sino a partir de ellos. Los moldes antiguos, pues; ya no se repetirán de manera automática; la crítica se cebará ahora, en opinión de Maravall, con «los manidos términos de unos

142 En opinión de Guy, Historia, p. 75, «Vives puso el dedo en la llaga de la degeneración escolástica; no propuso un sistema, sino un conjunto de puntos de vista constructivos, con vistas a un eclecticismo por venir; su doctrina pedagógica es célebre; sus ideas sociales prefiguran un cierto socialismo; su pacifismo y sus convicciones democráticas hacen de él un humanista plenamente comprometido, cuyas intuiciones iluminaron todo su siglo, mientras que su crítica serena, pero implacable, despejaba el terreno para las conquistas del progreso». «Su alegato en favor de la modernidad, en el que Platón tendrá su lugar junto a Aristóteles, y del Humanismo triunfador de uno y otro, no tuvo nada de sectario ni de hostil; menos irónico y cortante que Erasmo,» Prosigue Gruy, ibídent, p. 79: — prosigue Guy, ibídem, p. 79- «no usó nunca la burla ni la generalización apresurada. Fue un hombre discreto[...]».

143 Maravall, o.c., p. 304; para ese aire de esperanza que los nuevos tiempos traen, para esa nueva edad de oro (con testimonios de Vives, Erasmo y otros), véase Hale, La Europa del Renacimiento, pp. 29 y 326.

144 Por lo que hace a la lengua vernácula, remitimos a un largo trabajo nuestro, en elaboración todavía, titulado «El griego en la teoría lingüística del Renacimiento. En torno a la "conformidad" entre las lenguas y a su papel en la historia de la linguística»; un anticipo de él es «Sobre el griego en la teoría lingüística del Renacimiento español», en Actas del Congreso Internacional «Neograeca Medii Aevi». Prosa y verso en griego medieval». (Universidad del País Vasco, Vitoria-Gasteiz, 1994), en prensa.

145 Antiguos, p. 318. 
epígonos del peripatetismo» ${ }^{146}$ y tanto personajes como López Pinciano, como Jiménez Patón y González de Sala, con sus ideas sobre poética, ${ }^{147}$ darán énfasis a una acusada libertad frente al esquema clásico, básicamente aristotélico, libertad que incluso hoy día nos sorprende. No hay que perder de vista, por otra parte, que Galileo señalaba a los romos de mente neoaristotélicos de su tiempo, anclados en un Medievo de repeticiones machaconas de las sentencias del maestro «de los que saben», como Dante escribió, que el verdadero aristotélico era él mismo y no sus interlocutores. ${ }^{148}$ Pues bien, afirma también ese gran investigador que fue J.A. Maravall ${ }^{149}$ — del que tanto nos servimos en esta primera parte de nuestra lección-que «Lope y Velázquez, en términos semejantes, llevan a cabo una revolución galileana en sus campos respectivos» y que el primero, en concreto, en su Arte nuevo de hacer comedias, lo que pretende es «ejercer el papel de un nuevo Aristóteles».

Y si de aquí pasamos al terreno de la ciencia o del arte en relación con nuestro s. XVI, no son pocas las opiniones que podrían traerse a cuento para expresar lo mismo que acabamos de decir a propósito de la teoría literaria; recordemos, por ejemplo, aparte de lo que ya se ha mencionado en las páginas que anteceden, que, en otros pagos, W. Harvey, en sus Exercitationes de generatione animalium, Londres 1651, estampó la sonora frase que sigue: «Aristotelem ex antiquiis [...] sequor [...] tamquam ducem» ${ }^{150} \mathrm{y}$, sin embargo, se apartó de las concepciones del maestro; del mismo

146 Recordemos que, para Vives, In pseudo-dialecticos (Selestat, 1520), y tomamos la cita de Guy, Historia, p. 76, la ignorancia orgullosa de muchos maestros y su bárbara terminología debe ser estigmatizada, lo mismo que «su hermetismo, sus constantes paradojas, su confusionismo, su lucro y, por encima de todo, su tiranía mental. "Casi todo lo que se trata en los silogismos, oposiciones, conjunciones, disyunciones y explicaciones de los enunciados, son puros rompecabezas [quaestiones illae divinandi] que por pasatiempo se proponen a las mujerzuelas y los mozuelos ociosos" (Opera, III, 40; Obras, trad. Lorenzo Riber, II, p. 295). Vives atacó a aquellos sofistas (a menudo compatriotas suyos, titulares de las cátedras parisienses). "¡infecundos ingenios y, a mi parecer, nacidos más para la paja y para las algarrobas que para el grano!" (ibídem p. 58). La causa profunda de todo este desorden es el puesto desorbitante concedido a la dialéctica; se había hecho del medio un fin en sí mismo. "Pues la dialéctica es arte que no se aprende por ella misma, sino para que preste su concurso y sus servicios, como quien dice, a las artes restantes" (loc. cit; ; trad. L. Riber, p. 308)». Ataques parecidos contra esa adhesión rígida a un aristotelismo que se había transformado en «rígido y oscurantista», todavía más de lo que podía haber llegado a ser en la Edad Media, lanzó Giordano Bruno a finales del s. XVI contra los filósofos de Oxford. Aunque atraído por la especulación platónica, la decadencia del antiguo aristotelismo metafísico en beneficio de las especulaciones lingǘsticas y de los preciosismos de la gramática, de los sofismas en suma, llevó al italiano a fulminar la «modernidad» filosófica vestida con excelente griego y latín pero vacía de contenido. Para el mismo Bruno, en cambio, la filosofía de los antiguos estudiantes de Oxford, pese a su bárbaro latín y a ser frailes, había sido más profunda y fructífera. Sobre todo ello puede verse el trabajo de Frances Yates, «Shakespeare», pp. 262-279 (en concreto 276 y ss.), ya varias veces citado, y, sobre todo, «El conflicto de Giordano Bruno con Oxford» (que vio la luz en JWI, 2 [1938-39] y se halla recogido en Ensayos reunidos I. Lulio y Bruno, trad. esp., Méjico, D.F., 1990, pp. 241-270). Bruno, que para Yates influyó en Shakespeare, aunque es un filósofo «moderno» no por ello, sin embargo, «representa una ruptura completamente revolucionaria con el pasado medieval» («Shakespeare», p. 279), lo cual viene a insistir una vez más en esa especial continuidad que, entre Medievo y Renacimiento, hay que respetar.

147 Bibliografía de interés sobre aspectos que tocan a esta cuestión son, entre otros muchos, los estudios bien cono-

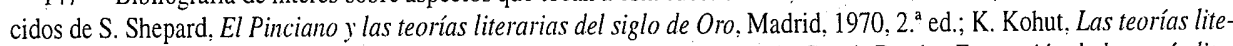
rarias en España y Portugal durante los siglos XV y XVI, Madrid, 1973; y A. García Berrio, Formación de la teoría literaria modema. II. Teoría poética del siglo de Oro, Murcia, 1980.

148 Maravall, o.c., p. 319, n. 116.

149 Ibidem, p. 119.

150 Citado por Schmitt, Aristotle, p. 154, n. 6. 
modo, Leonardo de Vinci, aludido ya en estas mismas páginas, maestro y artesano de la «experiencia», como E. Cassirer ${ }^{151}$ ha estudiado, manifestó de forma inequívoca una concorde opinión en su Códice Atlántico (f. 115-117v): «Si je ne puis comme vous citer les autorités. ${ }^{152}$ proclame Leonard de Vinci en face des scolastiques et des humanistes de son temps, je citerai quelque chose de bien plus grand et de bien plus digne, en me réclamant de l'expérience, la maîtresse de vos mâ̂tres. Ils s'avancent gonflés et pompeux, revêtus et ornés non par leur propre effort mais par les efforts des autres, et ils ne veulent reconnaître les miens; mais ils me méprissent, moi, l'inventeur, combien plus peuvent être blâmés ceux qui ne sont pas des inventeurs mais seulement les trompettes et les déclamateurs des oeuvres des autres [...] Ils diront que moi, qui ne possède pas de lettres - prosigue Cassirer en su cita de Leonardo- je ne puis bel et bien parler de ce que je veux faire: ne savent-ils donc pas que mes affaires sont à traiter plutôt par l'experience plutôt que par les paroles de autres? Comme celle-ci fut la maîtresse de tous ceux qui ont bien écrit, je la prends aussi pour maîtresse et la citerai en toutes occasions». La experiencia, pues —-son los nuevos tiempos-, es ahora un valor de peso que se opone al anquilosado razonamiento, hinchado de retórica y alejado de las cosas, ${ }^{153}$ que ha podido verse en épocas pasadas. ${ }^{154}$ Sin embargo, aparte de que este dirigirse a los hechos, a lo real, supone una vuelta a la naturaleza ${ }^{155}$ en cierto modo, un retor-

151 Individu et cosmos dans la philosophie de la Renaissance, trad. fr., París, 1983, pp. 195-196 (hay trad. esp.).

152 «Uomo senza lettere», como de sí mismo escribe Leonardo, no puede traducirse como «persona iletrada»; véanse las reflexiones a este propósito de Koyré, «Leonardo da Vinci, 500 años después», en Estudios, pp. 92-93.

153 No hay que pensar, advierte Cassirer, o.c., p. 197, que tengamos aquí una dualidad, una oposición entre «razón» y «experiencia»; ambas nociones son interdependientes. «ll n'est aucune expérience véritable sans analyse des apparences, sans résolution du donné, du complexe dans ses éléments fondamentaux [...] Ce que nous appelons le monde des faits est-il rien d'autre qu'un réseau de "principes rationels" d'éléments de détermination qui, dans l'être et le devenir concrets, s'interpénètrent et se superposent de mille manières et qui ne peuvent être séparés et reconnus dans leur signification et leur valeur singulières que par la force de la pensée? La valeur propre de l'expérience elle même est d'effectuer cette analyse, de mettre en évidence les facteurs singuliers qui entrent dans un phénomène complexe et de suivre séparément leur activité».

154 No está de más señalar de nuevo que en su De causis, según apunta Maravall, Antiguos, p. 459, Vives, años más tarde, exhortará a valorar el trabajo de artesanos y labradores ya que «de su práctica se saca el saber de la naturależa de las cosas, no de lo que dicen los ignorantes dialécticos»; véase también, Maravall, «La diversificación», p. 156.

155 Conviene traer aquí la opinión de H. Arens, La lingüística. Sus textos y su evolución desde la Antigüedad hasta nuestros días, I, trad. esp., Madrid, 1975, p. 92, para quien, junto a los estudios del latín y de otràs lenguas de cultura antiguas, «se desató, suministrada por otras fuentes, una corriente cada vez más impetuosa de la investigación en el terreno de la lengua vulgar» (la cursiva es nuestra). Arens explica esas fuentes a que hace alusión, señalando el interés que despertó por los dialectos el De vulgari eloquentia de Dante y «el carácter juvenil y audaz de la época» (ibídem, p. 93), que, mediante viajes y descubrimientos, puso a disposición de la curiosidad intelectual de la Europa de la época pueblos y lenguas extraños. A su juicio, «la profundización sólo en las lenguas antiguas, en el número de las cuales penetró muy pronto la tercera, el hebreo, y, por otra parte, la inclusión moderada pero progresiva de las lenguas europeas y extraeuropeas, condicionan la índole y el resultado de los esfuerzos en torno al lenguaje en este siglo» (la cursiva es nuestra). Este mismo punto de vista (el interés que el Renacimiento tiene por la naturaleza) es traído a colación por F. Lázaro Carreter, Las ideas lingüísticas en España en el siglo XVIII, Madrid, 1949, p. 128 (hay reed.), quien, a más de mencionar los elogios del toscano (Alberti) y del francés (Du Bellay) en el XV y XVI, respectivamente, presenta otros argumentos sobre los que nos extendemos en el estudio ya citado que preparamos en la actualidad. Remitamos finalmente a A. Mazzocco, Linguistic Theories in Dante and the Humanists. Studies of Language and Intellectual History in Late Medieval and Early Renaissance Italy, Leiden, 1993. 
no a lo que, en principio, nos ha de enseñar algo que luego - y sólo luego- estará también en los libros, ${ }^{156}$ aparte de esto, decimos, hay que señalar, como ya ha hecho magistralmente L. Olschi, ${ }^{157}$ que este verdadero retorno a la experiencia no habría podido dar fruto y alejarse de la escolástica si, a la vez - y esto es muy importante-, no hubiese dado también origen a un nuevo órgano de expresión: la lengua vulgar. En efecto, "se détacher du latin médiéval —afirma Cassirer-, ${ }^{158}$ construire et achever progressivement la langue volgare comme forme d'expression scientifique autonome était la condition nécessaire du développement de la pensée scientifique et de son idéal méthodologique». Pero hay más; esa «experiencia», que en muchas ocasiones, como acabamos de decir, se opone a la mera repetición de lo observado por las auctoritates y es una vuelta al mundo de «lo real», puede también interpretarse otras veces como algo de mucha mayor importancia, es decir, como auténtica «experimentación». ${ }^{159}$ No es la «experiencia», sino la «experimentación»,

156 Los argumentos expuestos por los pensadores renacentistas a propósito de los problemas del conocimiento son, con cierta frecuencia, polémicos. «Tales polémicas, a su vez ha escrito A. Heller en una obra a la que ya hemos aludido en nota dos veces sin citarla expresamente, El hombre del Renacimiento, trad. esp., Barcelona, 1980, p. 435-, oponían casi invariablemente a los «libros» tanto la experiencia como la especulación dirigidas al mundo real. Cuando Valla sostiene que desconocemos casi todo lo humano y que, por consiguiente, no tenemos necesidad de libros, apelando luego a la experiencia, lo que hace es manifestar una tendencia general y común a la erudición renacentista. La experiencia, sin embargo - subraya Heller de acuerdo con Cassirer-, no debe entenderse como experiencia sensible solamente. Si Valla hubiera pensado así, sus propios diálogos serían la mejor refutación de sus tesis. "Experiencia" significa también especulación cuando ésta se orienta hacia la realidad, si analiza los fenómenos nuevamente reconocidos desde un punto de vista nuevo y deja de embrollarse con temáticas filosóficas propias de la escolástica. La experiencia es el punto de partida de todos aquellos que se sirven de la propia cabeza para pensar en el mundo. La frontera ha de establecerse entre el pensamiento independiente y la falta de confianza en el pensamiento, entre el pensamiento "libre" y el "esclavo", entre la escolástica y el "árbol de oro de la vida". Cualquier otra forma de categorizar la gnoseología renacentista oscurecería las oposiciones y las semejanzas esenciales».

157 Geschichte der neusprachlichen wissenschaftlichen Literatur, I, Heidelberg, 1919, pp. 3 y ss., 30 y ss. y 53 y ss., especialmente (hay reimpr.); véase Cassirer, Individu, p. 77.

158 Individu, pp. 76-77.

159 En torno a Galileo, por ejemplo, los estudiosos han señalado el papel de la observación y la experiencia e incluso, como señala Koyré, "Galileo y Platón», artículo publicado en 1943 y recogido en Estudios, p. 152, la presencia en sus obras de «una ironía amarga con respecto a hombres que no creían en el testimonio de sus ojos, porque lo que veían era contrario a la enseñanza de las gentes de autoridad, o peor aun, que no querían (como Cremonini) mirar por el telescopio de Galileo por miedo a ver algo que hubiera contradicho las teorías y creencias tradicionales [...] Sin embargo, no hay que olvidar - y esto nos parece una observación muy penetrante- que la observación o experiencia, en el sentido de la experiencia espontánea del sentido común, no desempeñó un papel capital $\longrightarrow$, si lo hizo, fue un papel negativo, el del obstáculo- en la fundación de la ciencia moderna. La física de Aristóteles, y más aun la de los nominalistas parisienses, la de Buridán y Nicolás de Oresme, estaba mucho más próxima, según Tannery y Duhem, de la experiencia del sentido común que la de Galileo y Descartes». Significa esto que las críticas llenas de sentido común que los humanistas -empezando por Petrarca, como se verá más adelante- hicieron al mundo conceptual del Medievo no bastaban para dar origen por sí solas a una nueva ciencia y que ésta debería surgir no sólo de una vuelta a la realidad, fuera de la tiranía de las auctoritates, sino de algo más que la mera y neutra «experiencia». De otro lado, como señala D. Ynduráin, Humanismo y Renacimiento en España, Madrid, 1994, p. 385, refiriéndose a la obra de Francisco Falero, Tratado del esphera y del arte del marear: con el regimiento de las alturas: con algunas reglas nuevamente escritas muy necessarias, Sevilla, 1535 (quien, como muchos otros, zahiere la omnipresente alta valoración que por la latinidad en todos los sentidos sienten los humanistas), «que los nuevos científicos se burlen de los humanistas sólo significa que estos científicos se están constituyendo como grupo y que, como los humanistas en su día, tratan de hacerse un hueco, desplazando a las disciplinas existentes y ya instaladas. Por ello, también critican a los escolásticos y a Aristóteles [...] Pero suponer o predicar el valor científico de la oratoria humanista es demostrar que se acepta una muy pintoresca idea sobre qué sean lo que hoy en día llamamos ciencias. Así, establecer una conexión genética entre Luis Vives y la psicología experimental moderna no es más 
escribe Alexander Koyré, ${ }^{160}$ lo que desempeñó —más tarde sólo— «un papel positivo considerable. La experimentación consiste en interrogar metódicamente a la naturaleza; esta interrogación presupone e implica un lenguaje en el que formular las preguntas, así como un diccionario que nos permita leer e interpretar las respuestas. Para Galileo, como sabemos bien - concluye Koyré-, es en curvas, círculos y triángulos, en lenguaje matemático e incluso, de un modo más preciso, en lenguaje geométrico - no en el sentido común o de los puros símbolos- como debemos hablar a la naturaleza y recibir sus respuestas».

Como aspecto destacable también en nuestro siglo XVI, fruto inequívoco igualmente de esa actitud crítica contra el Medievo en lo que toca a las ciencias y técnicas, podríamos citar una infinidad de testimonios que se interesan por lo contemporáneo y por aspectos novedosos que van bastante más allá del mundo limitado del texto antiguo recibido. Por ejemplo, el caso de Andrés Laguna, traductor del Dioscórides (cuyo texto - según él mismo - fue revisado directamente con la ayuda de un manuscrito griego de Páez de Castro, aunque no estamos muy seguros de en qué medida, después del libro de A. Guzmán Guerra ${ }^{161}$ y las críticas a la habilidad de Laguna como helenista de M. Bataillon) ${ }^{162}$ es de cierto interés. Encontramos en su obra una multitud de referencias a la experiencia personal, detalles de la vida privada y usos «modernos» de lo antiguo, así como a los trabajos que hubo de arrostrar para realizar su empeño; además, para fomentar la atención a la materia de su estudio, este erudito traductor pedirá al rey que organice un jardín botánico. ${ }^{163}$ Otro estudioso, Gregorio de los Ríos, capellán de la Casa de Campo en Aranjuez, en su Agricultura de jardines (Madrid, 1592), ${ }^{164}$ mencionará con la devoción acostumbrada a Plinio y Columela, ${ }^{165}$ pero no dudará en insistir en que lo que se expone en su obra se basa fundamentalmente en su propia experiencia. Finalmente, el sevillano Alonso Barba, ${ }^{166}$ en un libro titulado Arte de los metales (Madrid, 1639), un poco posterior a la fecha que en estas páginas nos hemos trazado como límite para nuestras reflexiones, ya no habla de las «virtudes» de los metales como hacían los lapidarios medievales, heredados en buena parte de la Antigüedad, ${ }^{167}$ sino de sus pro-

que un juego de palabras; lo mismo que atribuirle a Pérez de Oliva la invención del telégrafo o teléfono...». Entre la mera «experiencia espontánea del sentido común» y la retórica humanista y, de otra parte, la naciente visión científica, parece haber un gran trecho que no todos logran recorrer; véase también Maravall, «Culturas periféricas: Renacimiento español y Renacimiento veneciano», artículo publicado en 1967 y recogido en Estudios de historia del pensamiento español, II, p. 115 , a propósito de la «experiencia individual y concreta» y su incapacidad para generar ciencia èn el Renacimiento español.

160 «alileo y Platón», pp. 152-153.

161 El Dioscórides de Laguna y el manuscrito de Páez de Castro, Madrid, 1978.

162 «Sobre el humanismo del Doctor Laguna. Dos libritos latinos de 1543», artículo publicado en 1963 y recogido en trad. esp. en Erasmo y el erasmismo, Barcelona, 1983, 2. ${ }^{a}$ ed., pp. 286-325.

163. Maravall, Antiguos, p. 464.

164 Véase sobre él A. Prieto, La prosa española del siglo XVI, I, Madrid, 1986, pp. 283-289.

165 La mayor parte de las descripciones de su Agricultura, asevera T.F. Glick, s.v. en el Diccionario histórico de la ciencia, II, p. 235, «parecen basadas por completo en sus propias experiencias, con citas de autores clásicos (Plinio, Teofrasto, Columela) tan sólo en una discusión sobre las parras».

166 Véase sobre él López Piñero, s.v. en el Diccionario histórico de la ciencia, I, pp. 97-100.

167 Sobre lapidarios antiguos y medievales véase, en general, F.A. Adams, The Birth and Development of the Geological Sciences, Nueva York 1938, pp. 28-32 y 143-161 (hay reimpr.). 
piedades, es decir: peso, dureza, fusión y otras (ni más ni menos que un paso hacia adelante desde una concepción meramente «cualitativa» de la realidad hacia otra «cuantitativa», vital para el desarrollo de la nueva ciencia); además, insiste Barba en las propias pruebas que ofrece, obtenidas gracias a sus múltiples experimentos, sobre una variada gama de aspectos. Como Maravall se encarga de informarnos, ${ }^{168}$ Barba, «siguiendo los resultados de observaciones experimentales, por ejemplo, nos dice que el color de las tierras puede ser indicio para el reconocimiento de metales y con este motivo ironiza sobre la tesis de Aristóteles de que la tierra pura debe ser blanca: el que "trata con metales" puede estar seguro de que una opinión tal carece de sentido - hay que dejarse de ejemplos antiguos, y aun de los modernos, para atenerse a aquellos que se presencia, que se controla». Permítasenos mencionar un caso todavía más llamativo, aunque también un poco más tardío; ${ }^{169}$ se trata del de Murcia de la Llama, autor del Compendio de los Meteoros del príncipe de los Filósofos Griegos y Latinos, Aristóteles (Madrid, 1615). Critica el autor en esta obra mil y una afirmaciones de Aristóteles acerca de cuestiones de geografía y geología; el viejo problema de la habitabilidad de la zona tórrida, negada por los antiguos, está ya resuelto hoy día, nos dice, puesto que la experiencia muestra «que no hay región debaxo del cielo que no sea habitable y todas habitadas». De otra parte, este mismo autor, que se apoya muy firmemente, como era de esperar, en lo conocido a raíz del descubrimiento de América, llega a afirmar, de acuerdo con Galileo, como ya se ha visto, que ser aristotélico es proseguir con la experiencia.

Pero dentro de este panorama un tanto apresurado que estamos trazando de nuestro siglo XVI -únicamente con la intención de que sirva de introducción lo más clarificadora posible a los estudios más concretos que han de seguir-, tal vez el ejemplo más sorprendente de esta nueva actitud frente a los conocimientos del pasado, ambivalente sin duda, aunque en ocasiones sustentada en firmes principios epistemológicos, pueda encontrarse en el terreno filosófico, del que hablaremos tan sólo un poco. Es justamente famosa -y ha merecido no pocos estudios_ ${ }^{170}$ la obra que Francisco Sánchez, en 1576, bajo el título De multum nobile et prima universali scientia quod nihil scitur, escribió para ser publicada más adelante, en 1581, en Lyon. Predecesora en cierto modo del cartesianismo, la postura escéptica de Sánchez ${ }^{171}$ arranca de un conocimiento profundo de Aristóteles al que, sin embargo, no puede dejar de hacer una pormenorizada crítica, cuyos colores ya hemos visto y volveremos a ver en otras latitudes y épocas. «¿Porque Aristóteles haya escrito, ¿me he de callar yo? - escribe Sánchez_- ${ }^{172}$ ¿Por ventura Aristóteles llegó a apurar en sus obras toda la potestad de

168 Antiguos, p. 465.

169 Traído igualmente a colación por Maravall, ibidem, p. 563.

170 Una bibliografía de interés, aparte de la ofrecida por Guy, Historia, señala también M. Ishigami-Jagolnitzer, «Le scepticisme grec, Francisco Sánchez et Pierre Charron», en Ishiganu-Jagolnitzer (ed.), Les humanistes et l'Antiquité grecque, París, 1991, pp. 39-49, estudio en que se analiza con detenimiento la presencia de los argumentos escépticos de los antiguos griegos en la filosofía de Sánchez.

171 Véase sobre ella, igualmente, R.H. Popkin, La historia del escepticismo desde Erasmo hasta Spinoza, trad. esp., Méjico, D.F., 1983, pp. 74-81; no obstante, el elogio de la duda era ya moneda común también en el s. XV, en el que Alfonso de la Torre, en su Visión delectable ya mencionada, según señala oportunamente Maravall, «La diversificación», p. 180, afirmará taxativamente: «ca el dudar ha sido en gran parte causa de saber la verdad». En sus Problemas y preguntas problemáticas, Alcalá, 1546, según el mismo investigador español, Juan de Jarava recomendará que «no se han de tratar sino las cosas de las cuales con razón se puede dudar».

172 Citamos por la trad. esp. (Madrid, 1972, Col. Austral), que lleva prólogo de Menéndez Pelayo y el título Que nada se sabe, pp. 35-36. 
la naturaleza y abrazó todo el ámbito de los seres? No creeré tal, aunque me lo prediquen algunos doctísimos modernos exageradamente adictos al Estagirita, a quien llaman el dictador de la verdad y árbitro de la ciencia. No: en la república de la ciencia, en el tribunal de la verdad, nadie juzga, nadie tiene imperio sobre la verdad misma. Yo tengo a Aristóteles — dice ahora más calmado Sánchez- por uno de los más agudos y sutiles escudriñadores de la naturaleza que hubo en el mundo; yo le admiro como a uno de los más fértiles ingenios que ha producido la especie humana; pero afirmo, también, que ignoró muchas cosas, que en otras muchas anduvo vacilante, que enseñó no pocas con grande confusión, que algunas cuestiones las trató sucintamente o las pasó y huyó por no atreverse a afrontarlas. Hombre era al fin, lo mismo que nosotros, -la cursiva es nuestray hartas veces, contra su voluntad, hubo de 'dar muestras de la limitación y la flaqueza humanas». Contra una dialéctica que, a ojos de Sánchez, resulta un vano ejercicio polémico que a nada útil conduce y menos, desde luego, a la ciencia, contra una lógica de la que nada puede sacarse y contra la que, en vano, el propio Aristóteles intentó luchar, ${ }^{173}$ nuestro filósofo se refugia en la experiencia como en algo infinitamente más prometedor y aboga por deslindar, en el terreno de la pregunta científica, la razón frente al argumento de la autoridad de los antiguos. «Yo — dice de nuevo un tanto acalorado_- ${ }^{174}$ no entendí jamás de Aristóteles ni de otros la más pequeña proposición; mas, impresionado por la lectura de sus libros, me apliqué a contemplar todas las cosas, y, vistas sus contradicciones y dificultades, para no ser envuelto yo por ellas, desamparados todos los filósofos, me refugié en las cosas, ejercitando mi propio juicio». «Yo —afirmará en otro lugar ${ }^{175}$ con el mismo énfasis en su personal opinión — sólo seguiré con la razón a sola la naturaleza. La autoridad manda creer; la razón demuestra las cosas; aquélla es apta para la fe; ésta para la ciencia». ${ }^{176}$

El experimento y la crítica, en definitiva — pues a eso parece reducirse su tan cacareada «experiencia»—, ${ }^{177}$ son para este autor los únicos criterios de la ciencia y, desde su posición escéptica, el proceder aristotélico presenta aun más críticas que las vistas usualmente; aquí y allá, además, una y otra vez, Aristóteles sale a relucir, aunque no se le mencione. Pero, lo que queda en el ánimo del lector es la importancia concedida al factor experiencia y la òposición razonada, aunque sea desde un tradicional «dogmatismo» escéptico, a la aceptación sin más de las opiniones de los antiguos; de nuevo aflora aquí en no escasa medida el tema que tan magistralmente han estudiado Maravall y Bianchi y, con él, nos es dado encontrar otra vez, por enésima vez, esa ambivalencia que, pese a toda crítica o desdén, fuerza a reconocer a los antiguos su genio desde el que, en definitiva, hemos podido alzarnos nosotros en nuestro propio vuelo hacia el conocimiento. «Para acrecentar este tesoro de la experiencia, para conservarle a través de los siglos, —afirmará Sánchez—178 imaginaron

173 Ibídem, pp. 138-139.

174. Ibídem, p. 54.

175 Ibidem, p. 37.

176 También el Brocense, como recuerda Gil Fernández, Panorama, p. 445, citando a Bataillon, escribió su defensa de la razón frente a la creencia a pie juntillas en lo que Platón o Aristóteles dijeron.

177 Popkin, Historia del escepticismo, p. 79, señala que «El experimentalismo propugnado por Sánchez ha sido considerado por algunos como prueba de que no era un verdadero escéptico, sino un empírico» que iría a allanar el terreno a Francis Bacon. No obstante, Popkin duda de que esta hipótesis sea acertada.

178 Que nada se sabe, p. 143. 
los hombres la escritura, merced a la cual todo lo que uno experimentó en su vida lo aprenda otro después en breve espacio. De esta suerte, las generaciones, las experiencias, los hechos, las invenciones de cada época, se van eslabonando y acreciendo sin cesar, por lo que, gráficamente, cada generación que surge a la vida y a la ciencia se ha comparado a un niño jinete en el cuello de un gigante». La vieja imagen que ya los medievales acuñaron vuelve a aparecer ante nuestros ojos, y no olvidemos que, casi por los mismos años, aparecerá también nada menos que en la obra de un músico, Tapia, en 1559. ${ }^{179}$ Sin embargo, lo que en Bernardo de Chartres, al parecer el creador de la imagen, se asemeja a una referencia exclusiva al legado de la Antigüedad, aquí, en el texto de Sánchez, da la impresión de tener ya un valor algo más general, que, de otro lado, no será la única variación experimentada por esta frase, divisa de numerosas generaciones. ${ }^{180}$ Es el pasado, el saber y la experiencia de nuestros antecesores lo que nos permite elevarnos. En fin, esta actitud epistemológica nueva, «la razón y la experiencia unidas contra el principio de autoridad», que dice Maravall, ${ }^{181}$ el interés por otras cuestiones de la actualidad, la encontramos también en la medicina, por ejemplo en el médico López de Villalobos ya mencionado en estas páginas, un autor muy citado a propósito de esas nuevas corrientes de pensamiento, así como en la obra del médico y filósofo Francisco Valles, ${ }^{182}$ al que también se ha aludido anteriormente, cuyos Controversiarum medicarum et philosophicarum libri decem (Alcalá, 1556) sostienen igualmente este enfrentamiento, crítico incluso, con la opinión de los teólogos en lo que toca a ciertos problemas. López de Villalobos, hablando de los cuatro elementos en el cuerpo humano y su equilibrio y unión, llega a decir: «Mas, yo no hablo agora con los teólogos; y, si los filósofos se acogen a ellos, harán como los malhechores que se acogen a la iglesia; por tanto, yo he mirado mucho en esto y he hallado una razón natural muy sutil». También una obra de este mismo Valles, el Libro singular de Francisco

179 Véase Prieto, La prosa, p. 277.

180 Según Baron, «La querelle», p. 320 «El símil escolástico sobre los enanos [...] fue repetido con frecuencia en los círculos científicos durante el siglo XVII (incluso por Isaac Newton) sin que nadie se sintiera ofendido; el pensamiento de que cada nueva época, habiendo avanzado un poco más en el camino del conocimiento, debía necesariamente tener un horizonte más amplio que sus predecesores, agradó a las generaciones que comenzaron a experimentar el crecimiento continuo de la ciencia». R.F. Jones, Ancients and Moderns: A Study of the Background of the "Battle of the Books», San Luis, 1936, p. 33, libro que comenta la tradición subyacente a la famosa obra de Swift, hace referencia a diversos aspectos de la Apology de Hakewill ya citada, según señala Baron, aunque no advierte que la defensa encendida de Hakewill de la capacidad del hombre de su tiempo y de sus posibilidades para no tener que limitarse a un segundo lugar frente a los antiguos no es sino un eco de lo que ya Juan Luis Vives había escrito en diversas ocasiones. En el De disciplinis de Vives, reimpreso en 1612 en Oxford, quince años antes de que la Apology de Hakewill viese la luz, Vives rechaza claramente el dogma de la superioridad de la sabiduría de los antiguos y estampa la frase famosa sobre la verdad y su «patencia» ante los hombres a que hemos hecho alusión. «No me considero -añadirá Vives - el igual de los antiguos, pero comparo mis experiencias con las suyas [...] Vosotros que buscáis la verdad, colocaos dondequiera que esperéis encontrarla»; véase, sobre este y otros pasajes del valenciano, Baron, «La querelle», pp. 320-1. «No sólo estas citas fueron utilizadas por la generación de Hakewill,» - añade Baron- «sino que también disponemos de por lo menos algunas pruebas que nos sugieren que fueron apreciadas en todo su valor. Todas [...] se hayan [sic] reproducidas casi al pie de la letra en Timber; or Discoveries, la bien conocida obra (publicada por vez primera en 1640) del gran contemporáneo de Hakewill, Ben Jonson, aunque Jonson no reconoce su deuda». Son muchos los estudiosos modernos, sin embargo, que han descubierto independientemente estos ecos de Vives en la crítica literaria inglesa del s. XVII.

181 Antiguos, p. 466.

182 Véase López Piñero, s.v., en el Diccionario histórico de la ciencia, I, pp. 391-394. 
Valles sobre las cosas que fueron escritas físicamente en los libros sagrados o de la Sagrada Filosofia, es decir, su De Sacra Philosophia, (Turín, 1587), de la que hay traducción española (Madrid, 1971), resulta de gran interés para la tradición aristotélica. En el último libro, donde las citas aristotélicas se cuentan por centenares, la tendencia seguida por este ilustre médico, en cuya obra no podemos entrar a fondo en la primera parte de nuestro trabajo, es interpretar como filósofo los lugares de la Biblia donde se habla de cuestiones físicas y procurar salvar la opinión de los teólogos ${ }^{183}$ su punto de partida, pues, es ortodoxo, en el sentido de que no hace sino tomar como referencia, en principio, las buenas relaciones que, desde los Padres Capadocios (s. IV) se habían fijado muy detenidamente entre razón y fe. Ahora bien, muchas de sus soluciones críticas y su eclecticismo han llevado a que algunos párrafos o capítulos estén censurados por la Inquisición. Valles, como otros médicos de la época, defiende la experiencia y menciona la opinión de uno de sus colegas, un tal Pereiro, ${ }^{184}$ cuya concepción acerca de las vías cognoscitivas -y por este orden-era: el juicio de los sentidos y la experiencia, el raciocinio y, sólo en tercer lugar, la autoridad de los doctores. «Esta inversión de jerarquías ya es relevante», señala Maravall, ${ }^{185}$ autor que para mientes también, a este propósito, en un pasaje del Viaje de Turquía —sea éste del autor que sea-, libro donde Mata y Pedro de Urdemalas discuten sobre si es cierto que los médicos son mejores filósofos que los teólogos. La razón que da el segundo para admitir la supremacía de los primeros es que los teólogos «siempre van atados tanto a Aristóteles que les parece como si dijesen: el Evangelio lo dice y no cabe irles contra lo que dijo Aristóteles, sin mirar si lleva camino, como si no hubiese dicho mil cientos de mentiras; mas, los médicos siempre se van a viva quien vence por saber la verdad». Indudablemente, esta nueva mentalidad está muy lejos ya del Medievo o, lo que tal vez sea más apropiado, del tipo de Medievo que los renacentistas se imaginaban como receptor ideal de sus críticas (a veces ajustadas, otras puras discusiones propias de «departamentos universitarios», como así las hemos llamado, por boca de Kristeller, en estas mismas páginas). Hay que seguir a la verdad ${ }^{186}$ y no a Hipócrates, Aristóteles o Plinio ciegamente, ya que, afirmará también Vives (que está en contra del anquilosado escolasticismò aristotélico, como también lo estarán más adelante y casi por las mismas razones Francisco Sánchez el Brocense [1523-1600] y el propio Quevedo más tarde), en muchos pasajes erraron aquéllos y, por tanto, no debemos enseñar únicamente con ejemplos de los antiguos; esa lucha que Francis Bacon (1561-1626) comenzará contra los falsos mitos, los eidola tribus, ${ }^{187}$ estaba, pues, declarada en España hacía tiempo ${ }^{188} \mathrm{y}$, en

183 El libro, con un esquema bien conocido, preludia en cierto modo, aunque a la inversa, los conocidos trabajos modernos que abordan la lucha entre la teología y la ciencia; véase, por ejemplo, A.D. White, Historia de la lucha entre la ciencia y la teología, trad. esp. Madrid, s.a. (la ed. original es de Nueva York, 1896), y, sobre todo, con una visión mucho más objetiva y general, J.H. Brooke, Science and Religion. Some Historical Perspectives, Cambridge, 1991.

184 Se trata de Gómez Pereira (1500-post 1558); véase sobre él López Piñero, s.v., en el Diccionario histórico de la ciencia, II, pp. 411-414.

185 Antiguos, p. 468.

186 No otra cosa es esta mención que una nueva aparición de otro tópico bien conocido; véase sobre él L. Tarán, «Amicus Plato sed magis amica veritas. From Plato and Aristotle to Cervantes», Antike und Abendland, 30 (1984), pp. 93124.

187 Sobre ellos, entre otros, véase P. Rossi, Francis Bacon: De la magia a la ciencia, trad. esp., Madrid, 1990, pp. 276 y ss.

188 Maravall, Antiguos, p. 471. 
1522, fuera de nuestras fronteras, habrá autores, como el cabalista francés Guillaume Postel, por ejemplo, que dirán que la razón y la autoridad vienen de Dios, pero que, durante siglos, la segunda ha estado secuestrada por los aristotélicos; habrá que volver, pues, a la razón y acabar con los aristotélicos para restablecer tanto la verdad humana como la divina. «La razón y la verdad» —en definitiva — ${ }^{189}$ serán reconocidas como común patrimonio de los hombres y, de acuerdo con ello, se pensará que «no pueden ser enajenadas ni por la autoridad docente ni por la autoridad política».

\section{EN BUSCA DE LAS RAÍCES: UNA OJEADA A LOS ORÍGENES REMOTOS DE LA CRÍTICA}

Por supuesto, como ya se ha adelantado varias veces, nadie debe pensar que todos estos testimonios meridianos de disenso, crítica, de «modernidad» en suma, que se concretan en el elogio de la práctica, de la experiencia, de lo contemporáneo, por fuerza han de ser concordes en sus pormenores, ni que, todos a una, los autores del s. XVI o sus predecesores van por esa única y misma senda o se polarizan, ya sea contra Aristóteles (o sus «secuaces»), ya contra Platón; la lectura de un manual, inteligentemente escrito, por cierto, como es el de Guy, varias veces mencionado en estas páginas, basta y sobra, según se dijo, para aclararlo. Si ya justo al final del XIV Bernat Metge, influido por Petrarca, ${ }^{190}$ se expresa con orgullo humanista acerca de las conquistas del hombre merced a su inteligencia, ${ }^{191}$ no hay que olvidar que este optimismo supone las críticas a ciertos aspectos del saber antiguo tal como había sido transmitido y formalizado en su enseñanza a lo largo del Medievo. Pero no es un caso aislado. Petrarca mismo, aludido ya varias veces en estas páginas, intenta antes que Metge disminuir la importancia de la lógica aristotélica, señalando que su estudio, mera palabrería, lleva a una cognitio terminorum, en vez de a una cognitio rerum; y, en España, Arnaldo de Vilanova y Raimundo Lulio, entre otros, formarán parte de esa reacción antiescolástica del s. XIV que también se manifiesta en el área de la literatura, como señala di Camillo. Tras ellos, a principios del s. XVI, la Breve disputa de ocho levadas contra Aristótil y sus secuaces de Hernando Alonso de Herrera, impresa probablemente en Alcalá pero escrita en Salamanca en 1517, es una más de las obras ${ }^{192}$ que nos muestran una oposición a Aristóteles de nuevo tan matizable que, para muchos investigadores, no debe interpretarse realmente como antiaristotelismo sin más. Está claro, hay que precisar de inmediato, que Hernando, en la obrita que nos ocupa y en otras de las suyas, ${ }^{193}$ manifiesta que la crítica es necesaria; pero no creamos que aboga por refugiarse en la

189 Para todo esto, ibídem, p. 475.

190 Para la influencia italiana sobre la literatura catalana en esta época en general véase, entre otros, Gómez Moreno, España, p. 46.

191 Véase di Camillo, ibídem, p. 38, y Maravall, Antiguos, p. 61.

192 Sobre el autor y su obra véase una puesta al día en el estudio de A. Ruiz Castellanos, «Hernando Alonso de Herrera: semblanza intelectual y metodología linguística», en Maestre-Pascual (coord.), Humanismo y pervivencia, pp. 966-967. Una reed. de la Breve disputa es la realizada por Bonilla y San Martín, «Un antiaristotélico del Renacimiento, Hernando Alonso de Herrera y su Breve disputa de ocho levadas contra Aristótil y sus secuaces», Revue Hispanique, 117 (1920), pp. 61-196.

193 En la semblanza intelectual que del autor traza Ruiz Castellanos, o.c., pp. 972-973, pueden encontrarse diversos pasajes de sumo interés para lo que ahora nos ocupa. 
independencia de criterios, en la libertad de espíritu, en la objetividad de la ciencia o en un hipotético platonismo; lo que hace es simplemente recordar que la única autoridad que él reconoce es la de los libros sagrados; ${ }^{194}$ nadie, además, según dice taxativamente, debería ser esclavo de las autoridades científicas, y, por lo tanto, sus personajes se declaran estudiosos de Aristóteles pero no sus esclavos, y es el propio filósofo griego el que, en la Breve disputa, se quejará del obsecuente proceder de sus seguidores: «veo — nos dice Aristóteles— que hay algunos glosadores que piensan que son [...] de hacer omenaje a sus maestros y no filosofar como libres sino como esclavos defendiendo cualquiera que sea la sentencia del libro que declaran. Yo no tengo que es bueno el que a sabiendas engaña $o$ adrede se engaña [...] Más me ofenden falsos testimonios que me levantan unos vanos que se honran conmigo y [...] en lugar de aclarar mis textos los enfrascan y anublan con sus glosas [...] retuercen mis dichos a falsos sentidos y aun [...] hay que a grand daño suyo y de sus discípulos [...]». Sería del todo incongruente, por tanto, escribe Ruiz Castellanos, ${ }^{195}$ pretender adscribir a Herrera «en alguna escuela. Sus modelos inmediatos son Valla, Nebrija y Trapezunte; pero no se priva de criticarlos. Tampoco se puede decir que sea antiaristotélico, según la expresión de Bonilla», ya que, aunque le critica, sin embargo le elogia todavía más. «No es —concluye este investigador - contrario a Aristóteles ni a Prisciano [a quien también critica] sino contrario a sus secuaces, que "disputan por autoridades" (Levadas, Bonilla, p.171); "que en lugar de razones arrojan testos," (ibídem, p. 172), "que se creen algo más que es razón, (ibídem,)». Escrita en versión latina y castellana, la Breve disputa o Disputatio le fue dedicada por su autor a Cisneros. Por poner otros ejemplos que ilustren la progresión en el tiempo de estas críticas en nuestra patria (y lo variado de su punto de vista), recordemos que Juan Ruiz, en el Libro de buen amor, se burla de la sabiduría de sus afectados contemporáneos cultos y que López de Ayala censura el lenguaje oscuro de letrados y teólogos. Sin embargo, para di Camillo, de donde nos limitamos a sacar estas últimas referencias, se trata sin más de una resistencia aislada, ya que, en este siglo, la lógica escolástica prevalece todavía y «oscurece a la tradición literaria basada en la claridad, la sencillez y la brevedad». En una fecha tan tardía como 1575, para dar otro ejemplo de la rica variedad de motivos y actitudes con que la crítica a Aristoteles se reviste en nuestra patria, Juan Huarte de San Juan podrá seguir diciendo en su Examen, ${ }^{196} \sin$ sentirse obligado a cautela alguna, que «los griegos fueron los

194 ¿Es ésta una actitud propia de un «moderno»? Al pronto diremos que no, pero incluso aquí caben matices; no olvidemos que tampoco Petrarca, que criticó a Aristóteles, lo era realmente. Como ha escrito A. Koyré, «El pensamiento moderno», artículo publicado en 1930, recogido en Estudios, p. 11, las invectivas del poeta italianò «contra los aristotélicos, contra la lógica escolástica, su "humanismo", su "agustinianismo" [...], no deben hacernos perder de vista lo reaccionario que es en el fondo. Combate a Aristóteles, pero ¿cómo? Es contra el pagano contra quien lanza sus ataques. Trata de acabar con su autoridad, pero es para instaurar —o reinstaurar - en su lugar la ciencia y, sobre todo, la sabiduría cristia$n a$, la autoridad de la revelación y de los libros sagrados. Lucha contra la lógica escolástica, pero en beneficio de Cicerón y de la lógica retórica, pues si admira a Platón es por fe, por espíritu de oposición, sin conocerlo [...] Nunca una oposición ha estado peor dirigida [...] Desde el punto de vista del pensamiento filosófico es una caída y un retroceso. Pero ahí está [...]». Petrarca no quiere la lógica aristotélica porque es sutil y la filosofía profunda del Estagirita le desagrada con sus tecnicismos; como un imposible eco de lo que ya hemos leído en Joseph Pérez, la opinión de Alexander Koiré, muchos años antes, resuena con claridad: «Petrarca y todo el humanismo, ¿no es en gran medida la rebelión de la simple sensatez, no en el sentido de bona mens, sino en el de sentido común?». Definir lo que es «moderno» no es fácil; ya lo advirtió Maravall en su estupendo libro.

195 Ruiz castellanos, o.c., p. 973; véase, con la misma opinión, Fraile, p. 248.

196 Examen de ingenios para las ciencias, Madrid, 1977 (ed. de E. Torre), pp. 290 y 364. 
hombres más discretos que ha habido en el mundo» y, junto con él, otros muchos autores, cada uno con su cuenta y su razón, continuarán mencionando sin tasa a Aristóteles, ajenos, al parecer, a los vendavales críticos que sobre este autor soplaban desde hacía mucho tiempo. Un ejemplo harto ilustrativo puede ser, entre otros, el caso de fray Luis de Granada, cuya obra consideraremos, junto con la de otros autores, en la segunda parte de este estudio.

Pero no sigamos anticipando acontecimientos; dejemos de lado por el momento lo que a vista de pájaro se ha venido diciendo hasta aquí en torno a la actitud no poco ambigua, ecléctica, frente al aristotelismo de nuestro s. XVI y las características de nuestro Renacimiento, y, antes de terminar esta primera parte, hagamos hincapié, con algo más de detalle esta vez, en el hecho incontrovertible de que la lucha contra el aristotelismo, la escolástica o ambos, o, lo que es lo mismo en muchas ocasiones, contra la auctoritas en general, se remonta a algo más atrás que las quejas de Bernat Metge o las de Petrarca. En un estimulante librito sobre la intelligentsia medieval, la «modernidad» de algunos de los intelectuales del s. XII, un período bien estudiado por Ch.H. Haskins, ${ }^{197}$ como es de sobra conocido, ha sido resaltada no hace mucho por J. Le Goff; ${ }^{198}$ Pedro de Blois, Bernardo de Chartres (autor que, al parecer - como acabamos de decir-, es precisamente el origen de la tan conocida imagen ya mencionada de los «enanos encaramados en los hombros de gigantes» ${ }^{199}$ aplicada a los herederos de la tradición antigua), Juan de Salisbury y algunos más desfilan por sus páginas. ${ }^{200}$ En concreto, podemos leer en ellas que Adelardo de Bath no dudó en afirmar que de sus maestros árabes aprendió «a tomar la razón como guía», en tanto que sus oponentes, según el propio filósofo, se contentan, como esclavos, con seguir «la cadena de una autoridad basada en fábulas. ¿Qué otro nombre darle a la autoridad que el de cadena?». ${ }^{201}$ Pero no se nos olvide que ya Abelardo dijo que recurría a su propio espíritu en vez de a la tradición, en otro de los gestos de desafío que și bien contribuyeron a llenar su vida de infortunio, también enaltecieron, la trágica honradez de su postura intelectual; ${ }^{202}$ más tarde, en el s. XIII, Gilbert de Tournai, magister

197 La rinascita del XII secolo, trad. it., Bolonia, 1972; y R.L. Benson y G. Constable (eds.), Renaissance and Renewal in the Twelfth Century; Cambridge, Mass., 1982.

198 Los intelectuales, pp. 29 y ss.

199 Añadamos a la literatura ya mencionada al respecto, esta vez en lo que toca a nuestro siglo XVI, el trabajo de Maravall, «La fórmula del Renacimiento español», artículo publicado en 1979 y recogido en Estudios de historia del pensamiento español, II, pp. 96-97.

200 Por cierto, que otro de los autores que menciona Le Goff, Los intelectuales, p. 35, a propósito de esta ilustración del s. XII, Daniel de Morley, en un escrito dirigido al obispo de Norwich, se sirve de otro tópico conocido, éste bien vivo en la tardía Antigüedad, escribe: «a nosotros que nos vimos liberados místicamente del Egipto, el Señor nos ordenó que despojáramos a los egipcios de sus tesoros». Véase sobre él F. Gasti, «L'oro degli Egizi. Cultura classica e Paideia cristiana», Athenaeum, 80 (1992), pp. 311-329, y recordemos que, en el mismo siglo, aparece también en Bizancio, como puede verse en el elogio fúnebre a Ana Comnena, a mediados del XII, obra de Jorge Tornikes (J. Darrouzès, Georges et Démètrios Tornikès. Lettres et discours. Introduction, texte, analyse, traduction et notes, París, 1970, p. 284). El tópico en cuestión tiene una cierta relación con el de la «bella cautiva» de Deuteronomio $21,10,13$, que aparece también en nuestro Medievo aplicado al saber profano; véase, por ejemplo, Bravo García, «Aspectos de la cultura griega en la Península Ibérica durante la Edad Media», Euphrosyne, 17 (1989), p. 362, n. 6. Para las quejas de Juan de Salisbury sobre esa falta de respeto antes los auctores véase Curtius, Literatura europea, I, p. 85.

201 Le Goff, Los intelectuales, p. 63.

202 Ibídem, p. 49; hemos releído con gusto lo que sobre este atormentado personaje, «not a great character - aside from his intellect», o, mejor dicho, sobre «the heart of Helö̈se», escribió H.O. Taylor en un hermoso y erudito libro, The Medieval Mind. A History of the Development of Thought and Emotion in the Middle Ages, II, Nueva York, 1919, 3. ad., pp. 29-54. 
en París, dio en decir que «los que escribieron antes que nosotros no son para nosotros señores sino que son guías», añadiendo que la verdad está abierta a todos y que todavía no ha sido alcanzada por completo; ${ }^{203}$ ni más ni menos que lo que Vives dirá siglos más tarde. Que la rebelión contra las auctoritates no es siempre un ataque directo a Aristóteles es cosa que debe darse también aquí por cierta, pero igualmente lo es, como es bien sabido, que el Aristóteles del s. XII no es el del s. XIII. En efecto, Le Goff llama la atención, ${ }^{204}$ entre otras cosas, sobre el hecho de que un filósofo como Alberto Magno, opuesto a la doctrina de la «doble verdad», averroísta, exprese con toda claridad la idea de que si Aristóteles era hombre y no Dios, entonces forzosamente pudo equivocarse tal como nosotros, un tema que, como ya se ha anticipado en estas páginas, ha sido detenidamente investigado en fecha reciente por L. Bianchi. En efecto, toma en consideración este último investigador como precedentes, junto a un trabajo de E. P. Mahoney, ${ }^{205}$ otros muchos estudios en los que se ponen en claro la sustancia de las críticas que, durante los siglos XIII y XIV se hicieron contra el Estagirita; aparte de ello, tras remontarse a las opiniones de Petrarca en su De sui ipsius et multorum ignorantia (1367), donde se critica a Aristóteles desde un punto de vista moral y religioso, ${ }^{206}$ que, más tarde, Valla y Ramus trasladarán a la lógica y, luego, otros llevarán al terreno de la física, Bianchi se extiende sobre la historia del tópico del error humano del hombre que fue Aristóteles, ya iniciado casi formalmente en Petrarca, comentando textos de Diderot y D'Alembert, Malebranche, Leibniz, Francis Bacon, Galileo, Gassendi, Pico, Agricola, Cardano, Sánchez, Pomponazzi y otros. Este topos, concluye, se ha ido cristalizando en su opinión, tanto en su contenido teórico como en su forma literaria, bajo un doble impulso: «da un lato la preoccupazione che certi entusiasmi filosofici si risolvessero in vere e proprie forme di idolatria, inaccettabili se non altro per motivi religiosi; dall' altro l'influsso dei classici greci e latini che, da Euripide a Senofane, da Cicerone al già ricordato Quintiliano, avevano indicato nell'errare una delle condizioni distintive dell'umana esistenza». ${ }^{207} \mathrm{Al}$ fin y a la postre —si es que esta explicación acierta—, va a resultar que un viejo topos se remonta a otro todavía más viejo; de todas maneras, los cambios sociológicos experimentados en el paso de la Edad Media al Renacimìnto, a los que ya nos hemos referido con cierta detención, tal vez hayan tenido también su influencia en el robustecimiento de una actitud contestataria ante las auctoritates, sea cual sea el origen medieval de ésta.

Es hora ya de terminar. A lo largo de esta exposición, ha sido nuestro deseo poner en claro que, pese a los cambios de perspectiva que tienen lugar en el tránsito de la Edad Media al Renacimiento

203 Le Goff, Los intelectuales, p. 91.

204 Ibidem, p. 108.

205 «Aristotle as "The Worst Natural Philosopher" (pessimus naturalis) and "The Worst Metaphysian" (pessimus metaphysicus): His Reputation among some Franciscan Philosophers (Bonaventure, Francis of Mayronnes, Antonius Andreas, and Joannes Canonicus) and Later Reactions», en O. Pluta (ed.), Die Philosophie im 14. und 15. Jahrhundert. In Memoriam K. Michalski (1879-1947), Amsterdam, 1988, pp. 261-273.

206 La opinión de Petrarca — véase Bianchi, «Aristotele», p. 521—es: «Credo hercle, nec dubito, illum [Aristóteles] non in rebus tantum parvis, quarum parvus et minime periculosus est error, sed in maximis et spectantibus ad salutis summam aberrasse tota, ut aiunt, via».

207 Bianchi, ibídem, p. 522; remite este investigador para su segunda conclusión a la obra de A. Otto, Die Sprichwörter und Sprichwörtlichen Redensarten der Römer, Hildesheim, 1962 (reimpr. de 1890), p. 165, s.v. «homo, humanus». 
- y no sólo en España - se mantiene, sin embargo, en buena parte, la unión entre ambos períodos, o, lo que es lo mismo, no nos es posible concebir el segundo como totalmente independiente del primero. Al mismo tiempo, se nos ofrece la posibilidad de intentar explicar algunos de esos cambios en función de los precedentes medievales - salvadas las cautelas de que Kristeller hablaba- y postular también (o aceptar cuando es evidente) que parece haber existido un cierto eclecticismo, una cierta «convivencia de dos mundos y dos épocas que, por distintas, se suelen considerar irreconciliables», tal como ha afirmado Salinas Espinosa más arriba, refiriéndose en concreto a nuestra realidad hispana. La historia del largo debate en torno a Aristóteles, sus obras y sus doctrinas, una discusión que tanto espacio ocupó desde mediados del s. XIV a finales del XVI y fue anticipada por autores aún más antiguos, todavía no se ha escrito por completo, según ha afirmado C. Vasoli. ${ }^{208}$ Estas páginas no pretenden, desde luego, escribirla, sino que se limitan a preludiar, con su análisis de algunos aspectos de interés, generales (y particulares), las modestas consideraciones sobre la pervivencia del aristotelismo en autores de nuestro siglo XVI que habrán de seguir.

\author{
Antonio Bravo García \\ Facultad de Filología \\ Dpto. de Filología Griega \\ Universidad Complutense \\ 28040 MADRID
}

208 «De Pierre de la Ramée à François Patrizi. Thèmes et raison de la polémique autour d'Aristote», $R S P h, 70$ (1986), p. 87; véase Bianchi, «Aristotele», p. 513, n. 7. 